\title{
WestVirginiaUniversity
}

THE RESEARCH REPOSITORY @ WVU

Graduate Theses, Dissertations, and Problem Reports

2005

\section{Characteristics of farmers' market vendors in West Virginia}

Stacy M. Miller

West Virginia University

Follow this and additional works at: https://researchrepository.wvu.edu/etd

\section{Recommended Citation}

Miller, Stacy M., "Characteristics of farmers' market vendors in West Virginia" (2005). Graduate Theses, Dissertations, and Problem Reports. 2186.

https://researchrepository.wvu.edu/etd/2186

This Thesis is protected by copyright and/or related rights. It has been brought to you by the The Research Repository @ WVU with permission from the rights-holder(s). You are free to use this Thesis in any way that is permitted by the copyright and related rights legislation that applies to your use. For other uses you must obtain permission from the rights-holder(s) directly, unless additional rights are indicated by a Creative Commons license in the record and/ or on the work itself. This Thesis has been accepted for inclusion in WVU Graduate Theses, Dissertations, and Problem Reports collection by an authorized administrator of The Research Repository @ WVU. For more information, please contact researchrepository@mail.wvu.edu. 


\title{
Characteristics of Farmers' Market Vendors \\ in West Virginia
}

\author{
Stacy M. Miller
}

Thesis submitted to the

Davis College of Agriculture, Forestry and Consumer Sciences

at West Virginia University

in partial fulfillment of the requirements

for the degree of

Master of Science
in

Agricultural and Environmental Education

\author{
Deborah A. Boone, Ph.D., Chair \\ Harry N. Boone, Jr., Ph.D. \\ Stacy A. Gartin, Ph.D. \\ Cheryl Brown, Ph.D. \\ Thomas R. McConnell, M.S.
Division of Resource Management
Morgantown, West Virginia \\ 2005
}

Keywords: farmers' market, farmers' market vendors, farmers' market income, product diversity, promotional methods, educational needs, obstacles to farmers' market success, West Virginia agriculture 


\section{ABSTRACT \\ Characteristics of Farmers' Market Vendors in West Virginia}

Stacy M. Miller

The purpose of this study was to identify characteristics of farmers' market vendors in West Virginia, including products, season extension methods, promotional strategies, and sales levels, as well as to identify the obstacles and educational needs relevant to farmers' market vendors. While the majority of products produced by vendors were vegetables, it was found that products such as processed products and live plants were used to extend marketing seasons. Meat and dairy were the least represented categories. Fewer than half of the vendors reported use of any season extension techniques.

While a slight majority of vendors appeared satisfied with current length of the market season and enforcement of market rules, many identified increased advertising as the most important priority for change. Common educational needs included education and outreach to consumers, pest control, value-added regulations, and ways of communicating with other regional farmers' markets. Chief obstacles to success included resellers, unfair or inadequate market management, and a lack of advertising. 


\section{ACKNOWLEDGEMENTS}

I would like to thank the following individuals, whose efforts and inspirations large and small proved instrumental to the completion of this study:

Dr. Harry N. Boone, whose expertise in survey design and data analysis helped to maintain some semblance of academic rigor. Thank you for always taking the time to answer even the most trivial of questions.

Dr. Deborah A. Boone, who unknowingly provided a lot of perspective on overcoming obstacles, and whose eagle eyes likely prevented a minor disaster or two.

Dr. Stacy A. Gartin, whose heart-felt words to the wise served as apt reminders to leave one's ego (insecure and otherwise) at the door. Thank you for your humor and unflagging enthusiasm. Dr. Cheryl Brown, whose passion for sustainable food systems in turn sustained me. Thank you for many contributions and your commitment to keeping the red felt-tip pen manufacturers of the world employed for a long time to come.

Thomas R. McConnell, whose decades of experience working with small farmers yielded inspiring anecdotes and a lot of moral support. Thank you for giving me the opportunity to work with and learn from farmers' market vendors and managers throughout West Virginia. Thomas McCutcheon, who granted me the time and the soap box to garner support among the wonderful folks at the Farmers' Market at Seneca Center.

Special thanks to Susan Sauter, David Saville, Jackie Shisler, Laura Himes, and Dr. David W. Hughes for their time and thoughtful suggestions on the development of the survey instrument. 


\section{TABLE OF CONTENTS}

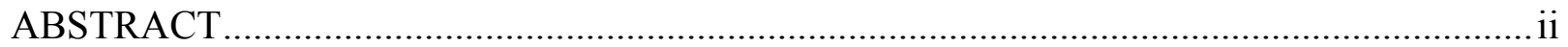

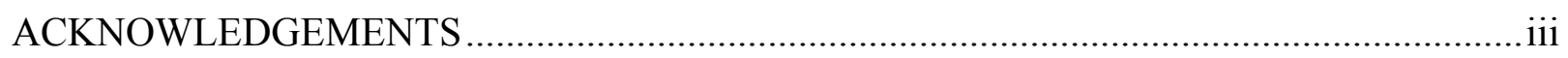

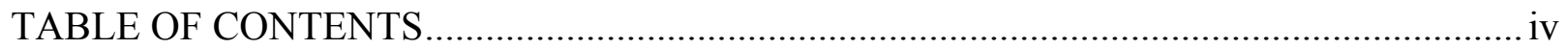

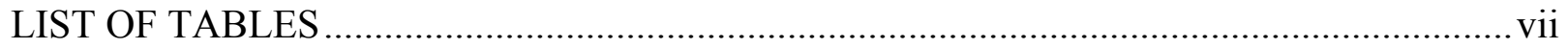

CHAPTER I - Introduction ................................................................................ 1

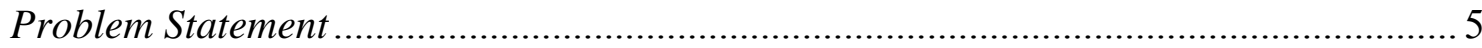

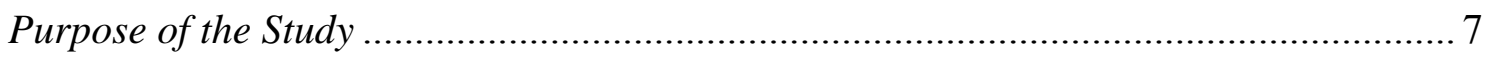

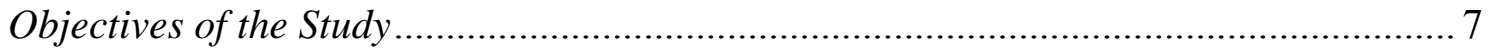

Research Questions............................................................................................ 7

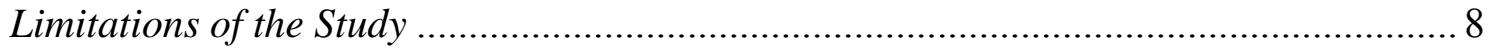

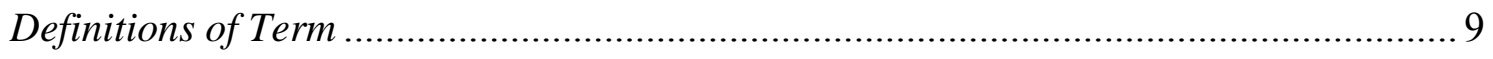

CHAPTER II - Review of Literature ..................................................................... 10

Defining Farmers' Markets .............................................................................. 11

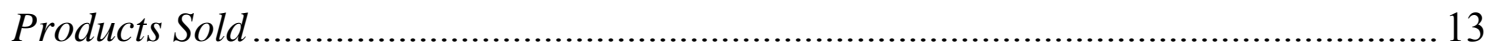

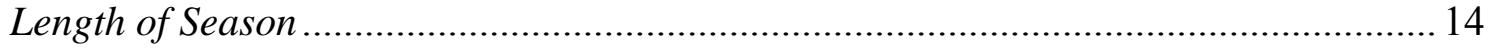

Promotional \& Pricing Methods ............................................................................ 15

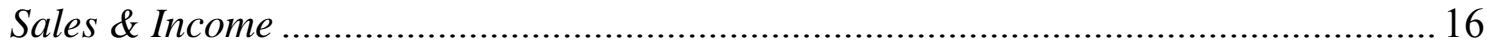

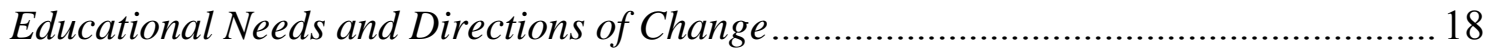

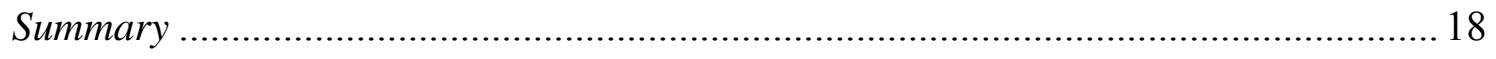

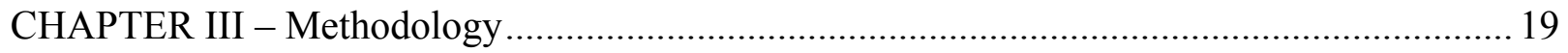

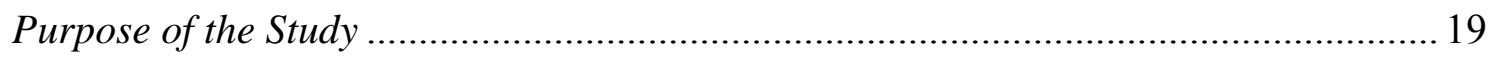

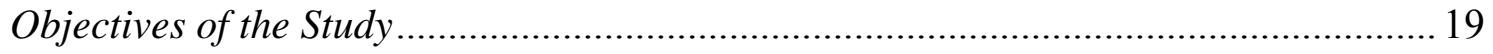




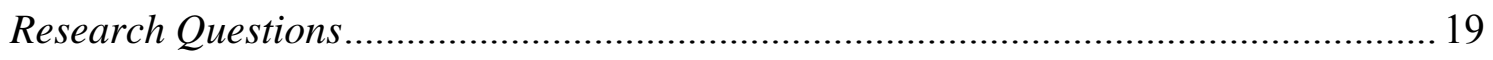

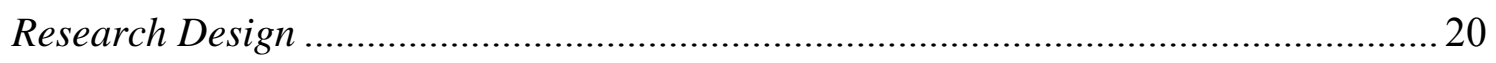

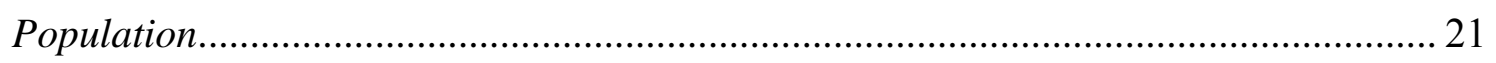

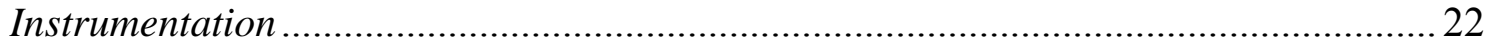

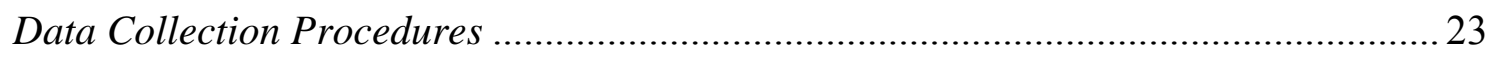

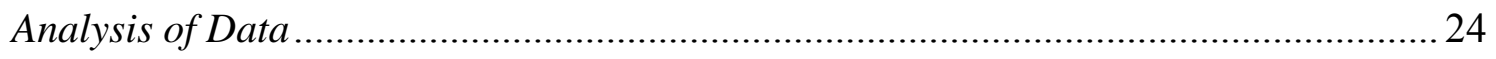

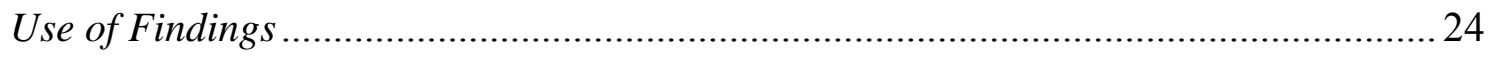

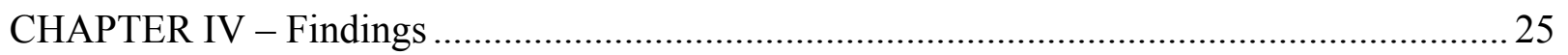

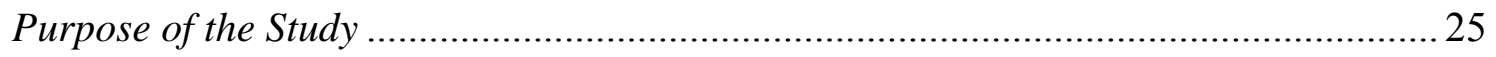

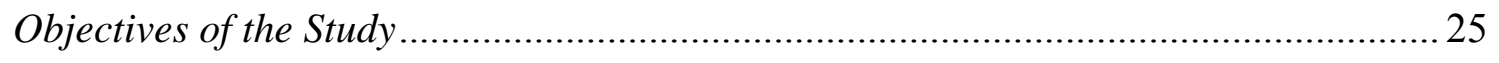

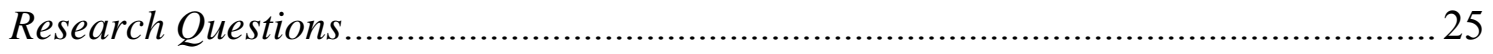

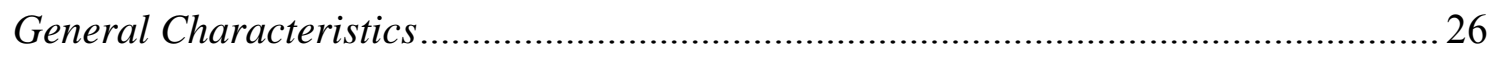

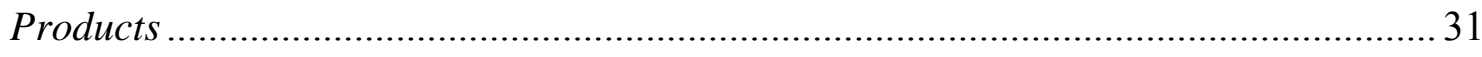

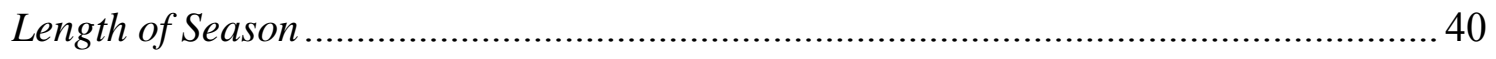

Promotional \& Advertising Methods at Farmers' Markets............................................ 43

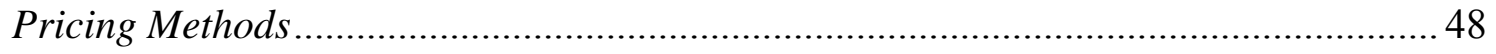

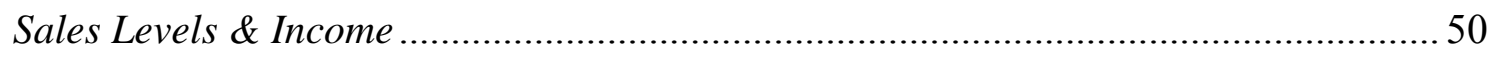

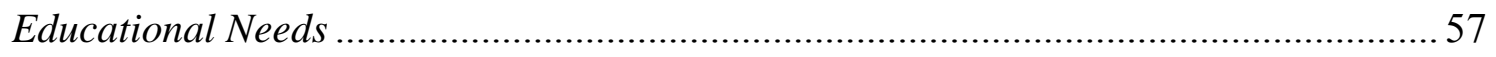

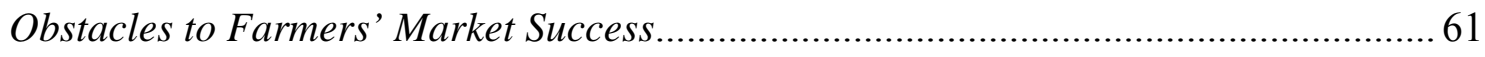

CHAPTER V - Summary, Conclusions, and Recommendations............................................... 65

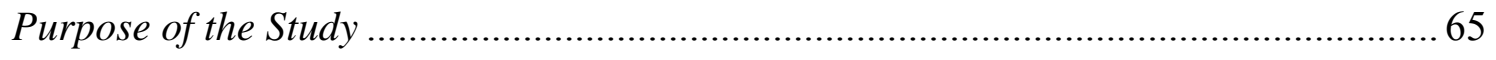

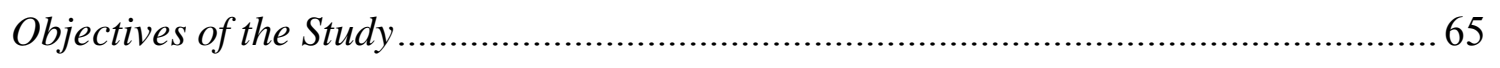

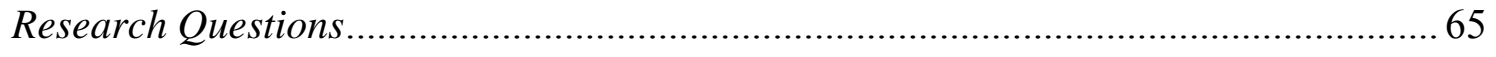




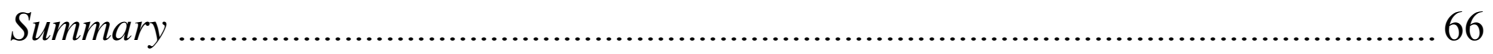

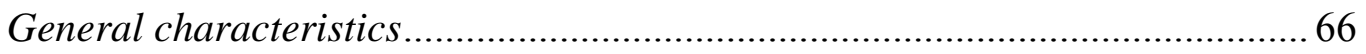

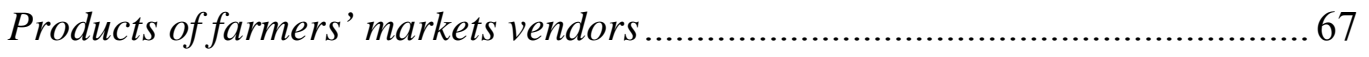

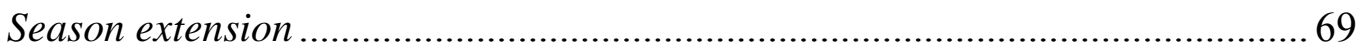

Promotional strategies used at farmers' markets .............................................. 69

Pricing methods used by farmers' market vendors............................................ 70

Sales levels and income of farmers' market vendors........................................... 70

Educational needs as perceived by farmers' market vendors ............................ 71

Obstacles to the future success of farmers' markets in West Virginia ............... 72

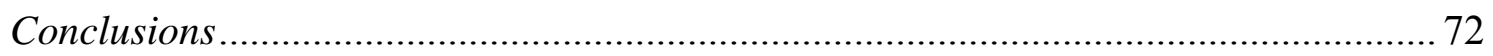

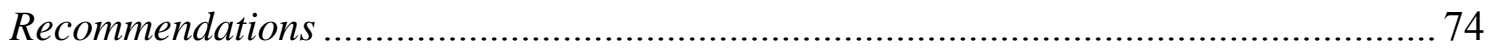

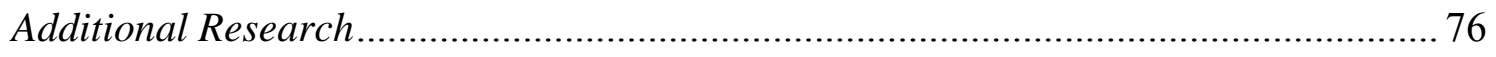

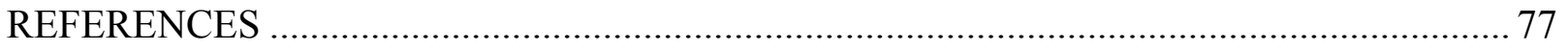

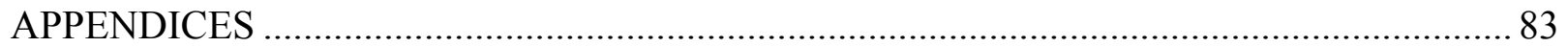

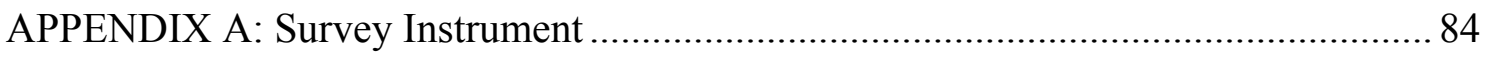

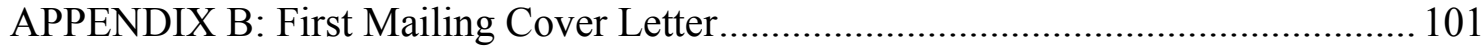

APPENDIX C: Second Mailing Cover Letter …………………………..................... 103

APPENDIX D: Product Matrix Summary ………….................................................... 105

APPENDIX E: Educational Needs as Identified by Farmers' Market Vendors........... 108

APPENDIX F: Obstacles to Success as Identified by Farmers' Market Vendors........ 112

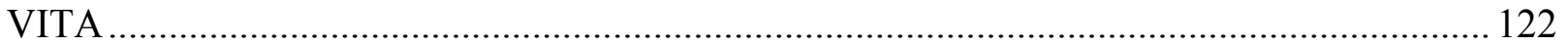




\section{LIST OF TABLES}

Table

Title

Page

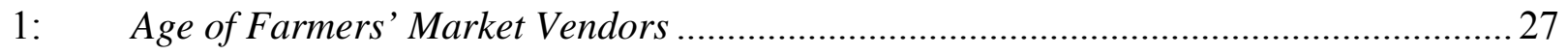

2: $\quad$ State of Residence of Farmers' Market Vendors .................................................... 28

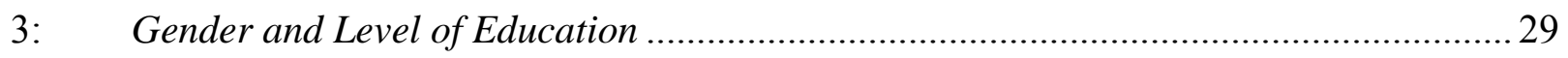

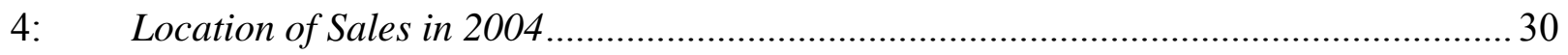

5: $\quad$ Summary of Farmers’ Market Attendance ........................................................... 31

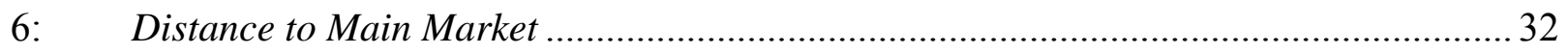

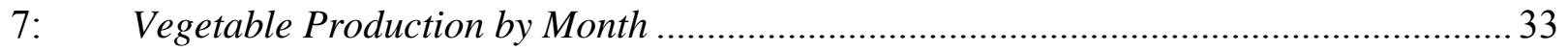

8: $\quad$ Dairy and Egg Production by Month................................................................... 34

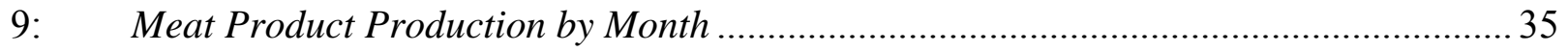

10: Live Plant Production by Month ....................................................................... 36

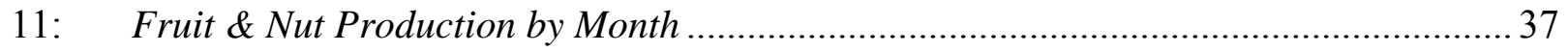

12: $\quad$ Herb \& Cut Flower Production by Month.............................................................. 38

13: $\quad$ Processed Product Production by Month ............................................................... 39

14: $\quad$ Projected Product Offerings for Next Season...................................................... 40

15: $\quad$ Weeks at Farmers’' Markets in 2004 .................................................................... 41

16: $\quad$ Season Extension Methods Used by Farmers’' Market Vendors................................... 42

17: $\quad$ Ideal Farmers’ Market Starting and Ending Times.............................................. 43

18: $\quad$ Promotional Strategies Used at Farmers’ Markets................................................. 44

19: $\quad$ Terms Used to Label Products at Farmers’ Markets ................................................ 45

20: $\quad$ Means of Communicating with Customers at Farmers’ Markets ................................ 46

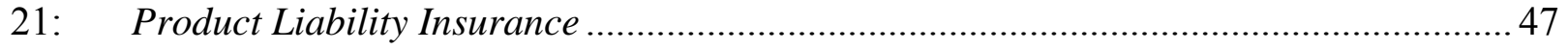


22: $\quad$ Summary of Directions of Change Desired by Farmers' Market Vendors

23: $\quad$ Farmers’ Market Prices Compared to Grocery Store Prices....................................... 49

24: $\quad$ Methods of Establishing Prices at Farmers’ Markets ............................................. 50

25: $\quad$ Average Daily Sales per Farmers’ Market in 2004 ................................................. 51

26: $\quad$ Total Farmers' Market Sales in 2004 and Level of Satisfaction with Profit Margin ..... 53

27: Farmers' Market Sales as a Percent of Total Business and Total Household Income .. 54

28: $\quad$ Summary of Hours Worked for Production and Marketing of Products ....................... 55

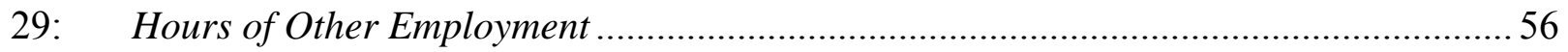

30: $\quad$ Farmers’ Market Nutrition Program Vouchers as a Percent of Total

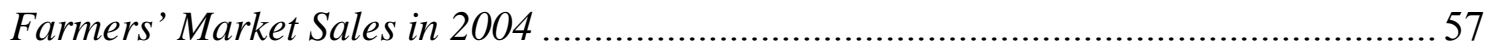

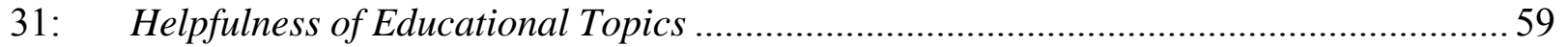

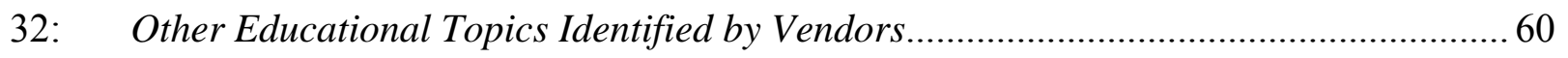

33: $\quad$ Obstacles to Future Success of Farmers’ Markets …................................................. 63 


\section{CHAPTER I}

Introduction

Farmers' markets have in recent years earned the myriad praises of small-scale farmers, health-conscious consumers, community developers, and local food advocates across the United States (Lyson, Gillespie, \& Hilchey, 1995). Now numbering 3,147 nationwide, such markets are becoming an increasingly important part of local food systems around the country (United States Department of Agriculture, 2002). As part of what is known as 'civic agriculture,' farmers' markets and other direct-to-consumer outlets together comprise a "locally-based agricultural and food production system that is tightly linked to a community's social and economic development" (Lyson, 2000, p. 43).

On a national level, several key issues contribute to the need for a transition toward civic agriculture. Those issues include rising transportation costs, human and environmental health concerns, biosecurity, declining farm profitability, and an increasing consumer demand for food products which provide a connection to the local agricultural community rather than large-scale, industrial farming (Gale, 1997; Lyson, 2000; Wolf, 1997). Much of the Mid-Atlantic region's fresh produce, distributed through terminal markets, travels over 1,500 miles before reaching the final consumer, partly due to a national $265 \%$ and $155 \%$ increase in the level of imports of fresh vegetables and fruits, respectively (Clemens, 2004; Pirog, 2003). Such a non-localized food system is, indeed, highly dependent on the continued availability of low cost fossil fuels (Pirog, 2003).

Direct marketing of locally produced foods, which significantly reduces the number of food miles, is common among small farms (Pirog, 2003; Steele, 1997). These farms can potentially earn a greater share of the consumer's food dollar by taking a more active part in the 
marketing and transportation processes typically performed by urban wholesale and retail establishments (Kohls \& Uhl 1998; Gale, 1997). Thus, a larger share of the retail food dollar returns to the rural communities where food is grown (Gale, 1997). It is through such a process that farmers' markets play a significant role in continued development of local food systems which are economically, socially, and ecologically sustainable for farmers, consumers, and the communities in which they live (Gale, 1997; Lyson, et al., 1995; Planck, 2004a).

While the roles of consumers, managers and vendors in farmers' markets has served as the focus for much national and state research in recent years, little has been done to investigate the unique issues facing direct-marketing producers in West Virginia. However, there are several important factors which indicate a need for further research into the value of farmers' markets in the state. These factors include high rates of nutrition-related health problems, a prevalence of small farms, and proximity to major metropolitan areas.

Researchers at the USDA have concluded that if the average U.S. diet were to meet Food Guide Pyramid recommendations through increased consumption of fruits produced within the United States, three to four million additional acres would need to be devoted to fruit production (Young \& Kantor, 1999). This same study revealed that the number of vegetable acreage would need to increase by two to three million acres, with nearly half of that devoted to "dark-green leafy and deep-yellow vegetables" (Young \& Kantor, 1999, p. 12). This is particularly relevant in West Virginia, which reports alarming rates of obesity. Between 1990 and 2000, the percentage of West Virginia residents with a Body Mass Index of 30 or higher consistently remained three to four percent higher than the national average (West Virginia Department of Health and Human Resources (WVDHHR), 2002). In 2000, 23.2\% of West Virginians were reported as obese, according to the Body Mass Index system (WVDHHR, 2002). More 
importantly, only $18.3 \%$ of adults in this category met the five Fruits-and-Vegetables-A-Day guidelines recommended by the USDA (WVDHHR, 2002). This fact, coupled with the growth of fresh produce voucher programs, signifies an opportunity for outlets like farmers' markets to better serve the economic and nutritional needs of communities throughout West Virginia.

Demand for fresh produce and other local agricultural products continues to grow due to an increased interest in supporting family farms and to the success of Farmers' Market Nutrition Programs, which allow licensed growers to accept redeemable vouchers from low-income shoppers in exchange for fresh produce. The Women, Infant \& Children (WIC) Farmers' Market Nutrition Program (FMNP) was established by Congress in 1992 to provide fresh, unprepared, locally grown fruits and vegetables to WIC recipients, and to expand the awareness, patronage and sales at farmers' markets (USDA, 2004f). Only farmers and/or farmers' markets authorized by the state agency may accept and redeem FMNP coupons. At the state level, WIC is administered by the West Virginia Department of Health and Human Services.

The Senior Farmers' Market Nutrition Program, which is administered at the state level by the West Virginia Department of Agriculture, provides low-income seniors with coupons that can be exchanged for eligible foods at farmers' markets, roadside stands, and community supported agriculture programs. 'Low-income seniors' are generally defined as individuals who are at least 60 years old and who have household incomes of not more than $185 \%$ of the federal poverty income guidelines.

By June of the 2004 season, 50,257 eligible West Virginia residents had participated in the Women, Infants \& Children (WIC) Farmers' Market Nutrition Program, with an average of $\$ 33.80$ in monthly benefits per person. The United States Department of Agriculture has allocated \$20,211,494 to West Virginia for the WIC Farmers' Market Nutrition Program, in 
addition to the $\$ 514,144$ awarded to the state for the Senior Farmers' Market Nutrition Program in 2004 (USDA, 2004e; USDA, 2004f). These programs, in addition to many consumers' growing desire to support local producers, are positioning West Virginia farmers' markets for increased growth in coming years.

As of $1992,88 \%$ of the farms in West Virginia were classified as small farms, a proportion exceeding that of any state in the nation (Steele, 1997). Not only does this density of small farms contribute to the state's rural character, but it also increases the potential for agriculture to play a significant role in the state's growing tourism industry (Steele, 1997). Preserving the state's agricultural base requires an attention to enterprises that are feasible on a small-scale, such as fruits, vegetables, and other high-value alternative crops. While the national average acreage per farm is 441 acres, West Virginia's farm size average is only 172 acres (USDA, 2004a), meaning that fewer farming families can take advantage of the economies of scale that make extensive agriculture viable. Higher return per acre is one method of preserving small farms, particularly in areas near growing suburbs (Gale, 1997). Among the many benefits to farmers inherent in farmers' markets is the fostering of entrepreneurship, since the direct contact with consumers allows farmers to "experiment with new items to respond to shoppers' demands" (Hamilton, 2002, p. 5).

Located within or adjacent to Metropolitan Statistical Areas (MSAs), many counties in West Virginia are experiencing population growth leading to increased demand for fresh produce and other local products (Clemens, 2004). Jefferson County, for example, is part of the Washington, D.C. MSA, and has experienced a 17.4\% population increase between 1990 and 2000, while the population of West Virginia as a whole only grew by $.8 \%$ (Census Bureau, 2000). The Charleston MSA incorporates Boone, Clay, Kanawha, Lincoln and Putnam counties 
(Census Bureau, 2003). In the northern panhandle, the Weirton-Steubenville MSA includes Brooke and Hancock counties while the Wheeling MSA includes Marshall and Ohio counties (Census, 2003). Although many of these counties have registered farmers' markets, little research has been conducted on the effects of increased population on their overall growth (West Virginia University Extension Service, 2004).

Farmers' markets play a vital role in enabling farmers to gain direct access to customers. Without this access, the existence of many small and medium-size growers would be threatened (Payne, 2002). Thus, direct-marketing serves as an important outlet for the state's agricultural producers. Between 1992 and 2002, the value of agricultural products in West Virginia sold directly to consumers for human consumption rose from $\$ 1,101,000$ to $\$ 4,588,000$, an increase of 317\% (USDA, 1999; USDA, 2004c). The interval between 1997 and 2002 saw an increase in the number of direct-marketing farms from 1,303 to 1,434 (USDA, 2004c). Though the North American Industry Classification System (NAICS) categorizes only $1.1 \%, 1.6 \%$, and $2.4 \%$ of West Virginia's farms as vegetable, fruit, and greenhouse and nursery operations respectively, there are $24.4 \%$ who fall under the 'Other' category, which includes any operation which has no one product accounting for $50 \%$ or more of its total production (USDA 2004b). The producers represented through direct-marketing outlets like farmers' markets are a much broader, diverse group than the 411 West Virginia farms who classified themselves as vegetables producers in the 2002 Agricultural Census (USDA, 2004d).

\section{Problem Statement}

Such an optimistic scenario of growth, however, is not without its obstacles. Various examinations into potential educational strategies that could encourage active participation in a more civic agriculture have identified Cooperative Extension "among potentially powerful allies 
in developing local food systems" (Feenstra, 1997, p. 30). In an unpublished report by the West Virginia Cooperative Extension Service, a survey of vegetable growers cited age as a reason that other vegetable growers were leaving the business and lack of both knowledge and foreseeable profit among the chief reasons more people are not entering into the vegetable growing business (McConnell \& Czemerda, 2002).

With $63.3 \%$ of West Virginia's farmers 55 years old or older, and $38.4 \% 65$ and over, it is clear that West Virginia's agricultural community at large is aging rapidly (USDA, 2004d). The increasing demand for fresh, locally grown produce will require the energies of a younger farming generation interested in diversified direct-marketing. Maryland farmers' markets report a $10 \%$ loss of farmers each year, partly due to retirement (Oberholtzer \& Grow, 2003). Respondents to the McConnell \& Czemerda (2002) survey also indicated a need for education and fact sheets from the West Virginia University Extension Service on both production and marketing skills. Because this study focused on the vegetable growing population in particular, it remains to be seen whether the farmers' market vendor population as a whole (including producers of tree fruits, cut flowers, animal products and other value-added enterprises) perceive similar educational needs.

The increasing demand for local agricultural products, in addition to the increasing age of the average farmer represents a distinct need to further identify and examine potential opportunities and barriers for both established and beginning agricultural entrepreneurs selling at farmers' markets (Oberholtzer \& Grow, 2003; USDA, 2004d). It is in this way that agricultural education programs can work in concert with promotional campaigns in order to further build upon the growths and successes of farmers' markets in West Virginia.

It is by identifying characteristics of farmers' market vendors in West Virginia that this 
study aims to contribute to a body of knowledge about farmers' markets in general that will allow educators, farmers, managers, and consumers to nourish a healthier, more sustainable food system.

\section{Purpose of the Study}

The purpose of this study was to identify the characteristics of farmers' market vendors in West Virginia. In addition, this study sought to identify the obstacles and educational needs relevant to farmers' market vendors and serve as a tool for the development of educational programming for both producers and consumers. The Extension Service and other community developers can therefore serve a greater role in the further development of farmers' markets as an integral part of sustainable local food systems in West Virginia.

\section{Objectives of the Study}

The objectives of this study were to identify general characteristics, products, promotional strategies, sales levels, season extension methods, and other characteristics of producers who use farmers' markets as a retailing outlet. In addition, this study aimed to identify educational needs and obstacles as perceived by farmers' market vendors in West Virginia. The objectives also sought to identify specific program objectives for Extension in the educational support of direct-marketing producers in West Virginia.

\section{Research Questions}

The following research questions were used in the development of this study:

1. What were the demographics of farmers selling at West Virginia farmers' markets?

2. What products were produced by farmers' market vendors in 2004 ?

3. How many months of the year were farmers able to market products via farmers' markets? 
4. What season extension methods were used by growers who sell at West Virginia farmers' markets?

5. What promotional and marketing methods were used by vendors at West Virginia farmers' markets?

6. How did vendors believe their prices compared with prices received for products of similar quality at supermarkets?

7. What were the gross sales earned by vendors at farmers' markets?

8. What percentage of the sales derived by vendors at West Virginia farmers' markets was attributable to WIC or Senior FMNP vouchers?

9. What percentage of the vendors' total household income was derived from sales at farmers' markets?

10. What changes did vendors perceive as necessary for overall improvement of farmers' markets?

11. What educational needs did farmers' market vendors identify as potentially helpful?

12. What obstacles did farmers' market vendors perceive as the greatest threat to the future success of farmers' markets in West Virginia?

\section{Limitations of the Study}

This study was limited to farmers' market vendors who participated in one or more West Virginia farmers' market(s) in the 2004 season. Individuals with residences in bordering states were included in the study as long as they used at least one farmers' market in West Virginia as a marketing outlet. Not targeted in the population were agribusinesses residing in West Virginia which use farmers' markets located solely in other states as a marketing outlet. 


\section{Definition of Terms}

Mid-Atlantic Region: A cluster of states including Delaware, District of Columbia, Maryland, New Jersey, Pennsylvania, Virginia, and West Virginia (Payne, 2002).

Small farm: Though there are many competing definitions used in the description of small farms, this study's definition refers to the USDA classification of having gross sales of less than $\$ 20,000$ per year (Steele, 1997). 


\section{CHAPTER II}

\section{Review of Literature}

Small farm enterprises in West Virginia, like many throughout the United States, have felt increasing pressure to maintain economic viability. National trends point to a decline in the number of farms as the average farm size continues to increase, largely due to vertical integration, farmland development, and a host of other issues which threaten small farms (Steele, 1997; USDA, 2004g). Such pressure encourages many to pursue direct-marketing outlets like farmers' markets in order to continue farming on either a full-time or part-time basis (Gale, 1997).

Though the evolution of farmers' markets in the United States has its roots in a longstanding global tradition of subsistence agriculture and bartering, they began to receive official recognition upon the passing of Public Law 94-463, the Farmer-to-Consumer Direct Marketing Act of 1976 (Brown, 2002). Though national research into the growth of farmers' markets has been hampered by scant or inconsistent data counts in different states, it has been estimated that the national total rose nearly 500 percent between 1970 and 1986 (Brown, 2002). According to the USDA, the number of recognized farmers' markets rose from 1,755 to 3,706 between 1994 and 2002 (USDA, 2002).

In a 2000 study which surveyed the 2,863 farmers' markets identified across the country, it was discovered that 66,700 farmers served 2,760,000 customers per week (Payne, 2002). The study revealed annual weekly sales totaling \$888 million during peak season in 2000. The MidAtlantic region far exceeded all six other regions in its sales per vendor per year, at over $\$ 32,682.00$ (Payne, 2002). Because nearly 300 additional markets had been developed between 2000 and 2002, one can only speculate about the collective economic significance in more recent 
years (USDA, 2002). For agricultural producers, many cite receiving retail prices, personal interaction, and high demand for high quality produce among the chief reasons for choosing to sell at farmers' markets (Govindasamy, Zurbriggen, Italia, Adelaja, Nitzsche \& Van Vranken, 1998b; Henneberry \& Agustini, 2002). While 85\% of market managers in Maryland, Washington, D.C. and southern Pennsylvania reported that the number of vendors had increased in the past three years, more than half of those in the region still have room to accommodate new vendors (Oberholtzer \& Grow, 2003).

The Chesapeake Fields Institute recently conducted a study which surveyed both consumers and producers in Maryland. A surprising $78 \%$ of consumers responding to their survey wanted to buy local or organic foods at farmers' market, a higher percentage than those seeking to buy the same kinds of products at either gourmet food stores or natural supermarkets. In their study of producers, which surveyed organic and 'organic interested' producers in Maryland, $74 \%$ stated that they preferred to sell locally, and $46 \%$ ranked their interest in selling at farmers' markets as a 'four' or 'five' on a scale of increasing interest from one to five (Chesapeake Fields Institute, 2004). While $40 \%$ of the survey's respondents currently sold at farmers' markets, $30 \%$ were specifically interested in the development of additional farmers' markets (Chesapeake Fields Institute, 2004).

\section{Defining Farmers’ Markets}

Both Maine and California have used their state laws to define the term farmers' market in order to regulate its use. This stands in contrast to the majority of states, including West Virginia, which permit more liberal use of the term. Hamilton (2002), in researching the rules and regulations of farmers' markets throughout the country, found a need to develop some kind of universal definition based on several key characteristics. These include farmers selling 
produce and food that they raise or create:

1) To individual customers

2) At a temporary location, often on public property, such as a street or parking lot

3) On a periodic basis, typically once or twice a week

4) For a set period of time, usually 3 or 4 hours

5) During the local growing season, usually 5 or 6 months

6) Operated by a government or non-profit organization (Hamilton, 2002, p. 3).

Such characteristics do not, in general, allow for the inclusion of state-run markets which act as retail outlets, selling local produce to customers but not facilitating direct farmer-consumer interaction. Though some markets are conducted in permanent structures like pavilions, they are they are still used only temporarily as farmers' markets and included in such a definition.

As in any industry experiencing steady growth, farmers' markets are not entirely without certain obstacles, which require attention if such outlets are to continue to grow and remain viable for individual farmers and producers. Marketers and managers long involved with the farmers' market movement in the United States admit that markets can lose their competitive edge over grocery stores if they are not completely committed to the standards of quality and service that make markets attractive to consumers (Corum, Rosenzweig \& Gibson, 2001; Planck, 2004a). Because farmers' markets rely heavily on personal farmer-shopper interaction, building and retaining customer loyalty are of ultimate concern for continued growth and success. In fact, a study of Oklahoma vendors revealed that $64.1 \%$ of respondents measured their success primarily from having return customers (Henneberry \& Agustini, 2002).

While many farmers' market studies have been conducted throughout the United States, many are directed to managers rather than producers. Nevertheless, reviews of such manager 
surveys, in addition to vendor surveys conducted at the state level in Oklahoma and New Jersey, reveals valuable information relevant to the future study of vendor populations. Because of the importance of farmers markets in a complete marketing plan, more effort needs to be made to develop techniques for designing, developing, and improving farmers' markets on local, state, and federal levels (Payne, 2002).

\section{Products Sold}

In a 1984 study of consumer preference conducted in West Virginia, data revealed that residents prioritized quality as the primary reason to shop at a farmers' market (Jack \& Blackburn, 1984). This same study noted that $44.4 \%$ of respondents cited limited volume/variety as a reason for nonuse or dislike of farmers' markets and tailgate markets (1984). This is in keeping with recommendations from experts who claim that "successful growers at farmers' markets participate in the market regularly, have a diverse mix of products within their stall or contribute to the overall product mix in the market" (Corum, et al., 2001, p. 13). Such trends in diversification include different types of unusual or organic produce as well as baked goods, preserves, animal products, cut flowers, and bedding plants, all of which can potentially increase profit margins (Corum, et al., 2001; Govindasamy, Hossain \& Adelaja, 1999; Planck, 2004a).

Researchers at Rutgers University who surveyed consumer perceptions of farmers' markets found that while nearly $90 \%$ rated the quality of products at farmer' markets as 'excellent or very good,' only half rated variety of products as excellent or very good (Govindasamy, Italia, \& Adelaja, 2002). In fact, many market managers in Maryland, Washington, D.C. and Pennsylvania cited recruitment of vendors with certain value-added products as an urgent issue of importance (Oberholtzer \& Grow, 2003). Among farmers' market vendors in Oklahoma, only $32.8 \%$ reported selling value-added products, while $22 \%$ reported 
that more information was needed on value-added products (Henneberry \& Agustini, 2002).

Farmers in West Virginia, too, have used value-added products as a means to increase income, and many feel that more information is needed by both producers and educators (Lewis, 2002).

Due to rising concerns about food safety, chemical residues, and the ecological sustainability of farming, sales of organic products have increased dramatically in recent years, particularly at outlets like farmers' markets. West Virginia, like most states, has experienced a rapid increase in the number of certified organic farms and in the level of organic product sales overall (USDA, 2004c). While little information is available concerning the supply or demand for organic or eco-labeled agricultural products specifically in West Virginia, 64\% of New Jersey vendors said that customers were requesting organically grown products. Simultaneously, only one-quarter of these farmers were actually growing organic products, indicating that opportunities exist in increased marketing of organic products at farmers' markets (Govindasamy, et al.,1998b).

Adequate product diversity, including a mix of value-added and organic products, could serve to attract and retain customers, possibly by contributing to an atmosphere conducive to convenience, or 'one-stop-shopping'. A diverse selection of products can help fulfill shoppers' needs and encourage them to spend more each week. While farmers and agricultural educators have not historically advocated such a consumer-driven marketing approach, recent research indicates a role for Extension in encouraging diversification at farmers' markets (Abel, Thompson \& Maretzki, 1999).

\section{Length of Season}

Along with product diversity, the number of weeks local products are available via farmers' markets may represent a limiting factor to customer loyalty and overall success. The 
national census survey of markets conducted in 2000 revealed that $25 \%$ of those in the MidAtlantic were open year-round, with an average season length of 20 weeks (Payne, 2002).

While maintaining sufficient, continuous supplies throughout the year may prove difficult for many markets, many experienced managers advise growers to, at a minimum, "choose products to stretch the season from, say, June until November to maximize returns and keep your customer base" (Corum, et al., 2001, p. 19). While limited research exists exploring the relationship between season length and direct-market success, it seems that many growers recognize the importance of extending the marketing season and have requested information on season extension techniques (Henneberry \& Agustini, 2002). Good return from markets, according to many experienced direct-marketers, may require spring, summer, autumn and winter crops, and many successful growers recommend season extension via covers, cold weather crops, and successive plantings (Planck, 2004c).

\section{Promotional \& Pricing Methods}

Even young lemonade stand entrepreneurs are likely aware of the critical importance of promotion in marketing, even for products which supposedly 'sell themselves'. At the most basic level, those with experience advise that "food without prices doesn't sell well" (Planck, 2004b, p. 5). Posting signs indicating price and product information, providing samples and recipes, and offering bulk discounts were all methods used at many New Jersey and Oklahoma farmers` markets (Henneberry \& Agustini, 2002; Govindasamy, et al., 1998b). A large majority of New Jersey vendors indicated that they promoted sales by offering information on how to prepare produce, with even more of them inviting customers to sample their products (Govindasamy, et al., 1998b). Oklahoma respondents also indicated that they perceived a need to increase the amount of advertising on behalf of the market in general in order to increase 
numbers of both customers and vendors (Henneberry \& Agustini, 2002).

Seventy-five percent of Maryland producers responding to the Chesapeake Fields Institute survey used one or more value-added labels when marketing their products. These included 'natural,' 'free range,' fresh-picked,' 'heirloom,' 'local,' 'organic,', and 'pasture fed,' among others (Chesapeake Fields Institute, 2004).

While direct-marketing presents opportunities to capture a larger share of the food dollar, suitable pricing methods play an important role in maximizing profitability when selling at farmers' markets (Planck, 2004c). Vendors must undertake the responsibility of pricing their products such that they realistically account for both expenses and profits.

Among the most common pricing methods used in the Oklahoma study were grocery store comparison, matching other vendors' prices, and cost of production plus mark-up (Henneberry \& Agustini, 2002). Similarly, marketers in New Jersey more heavily relied on comparisons with chain stores and wholesale markets as pricing methods rather than costaccounting or mark-up methods (Govindasamy, et al., 1998b). While no comparable study exists for pricing methods in West Virginia, the 1984 survey of West Virginia households revealed that $60 \%$ of consumers believed produce purchased directly from farmers was priced lower than produce purchased in grocery stores, and respondents saw limited volume and variety as a bigger problem than high prices at direct markets (Jack \& Blackburn, 1984).

\section{Sales and Income}

Scant previous research on farmers' market vendors in West Virginia means that little data is available which includes the economic contributions of those selling agricultural products other than fresh produce. West Virginia University's study of vegetable producers revealed that while $60 \%$ spent $20-30$ hours per week vegetable farming, nearly three-quarters had annual 
vegetable income of $\$ 5,000$ or less (McConnell \& Czemerda, 2002).

While this income may be partially accounted for by the relative seasonality of vegetable production, it nevertheless indicates there is potential to increase the profitability of supplementary income, particularly for vendors specializing in fresh produce. A study of directmarketers in New Jersey revealed that farmers who sell their products directly through directretailing are $14 \%$ more likely to be in the high-income category compared to those who are not primarily retailers, and even higher for those selling value-added products like breads, pies, or jams (Govindasamy, Hossain, \& Adelaja, 1999).

Henneberry \& Agustini (2002) found that 49\% of farmers' market vendors in Oklahoma had total annual household incomes of $\$ 39,999$ or less. While $52 \%$ indicated that they did not work off-farm jobs during the market season, only 5\% claimed that sales from farmers' markets constituted their full-time income. Among their respondents, 43\% considered their income from farmers' markets as part-time income, with another $27 \%$ considering it hobby or extra income. This is in keeping with the fact that most respondents did not have a business plan for their farmers' market sales. Nevertheless, nearly half indicated that their number one reason for choosing to sell at farmers' markets was because they received retail value for their products.

Though income derived from New Jersey farmers' markets varied widely among respondents, with sales at markets comprising the entire income for some vendors, the overall mean was $37 \%$ of total gross income (Govindasamy, et al. 1998b). A majority (61\%) claimed to be "very satisfied" or "satisfied" with their profit margins at farmers' markets (ibid.).

For all the potential benefits inherent in farmers' markets, profitability will ultimately dictate their sustained growth and success (Planck, 2004a; USDA, 2000). 


\section{Educational Needs and Directions of Change}

While product mix, season length, promotion, pricing, and income all represent issues of opportunity and concern for farmers' market success, it remains to be seen exactly how these and other limiting factors exist in West Virginia. In a unique focus group of direct marketers and facilitators from selected markets across the United States, researchers identified needs such as marketing skills, future farmers, consumer education, technical assistance, regulatory checklists, and attracting customers to rural locations (USDA, 2000).

The study conducted by the Chesapeake Fields Institute identified several barriers to marketing successfully, with eight out of ten vendors specifically indicating that they wanted help with marketing. Obstacles mentioned by these producers included having enough time for both production and marketing, "difficulty in getting across the benefits of local, seasonal products to potential buyers," and regulatory issues related to eggs and dairy products (Chesapeake Fields Institute, 2004, p. 18).

\section{Summary}

Oberholtzer and Grow (2003), in their analysis of farmers' markets, made strong recommendations for practical research on farmers' markets in the region, including “demonstrating the benefits farmers' markets bring to Mid-Atlantic communities and pinpointing the areas in which improvements are needed" (p. 20). Though their study limited its survey to farmers' market managers, other state-specific studies have targeted vendor populations in an effort to identify potential areas of improvement for sustained farmers' market viability. 


\section{CHAPTER III}

\section{Methodology}

\section{Purpose of the Study}

The purpose of this study was to identify the characteristics of farmers' market vendors in West Virginia. In addition, this study sought to identify the obstacles and educational needs relevant to farmers' market vendors and serve as a tool for the development of educational programming for both producers and consumers. The Extension Service and other community developers can therefore serve a greater role in the further development of farmers' markets as an integral part of sustainable local food systems in West Virginia.

\section{Objectives of the Study}

The objectives of this study were to identify general characteristics, products, promotional strategies, sales levels, season extension methods, and other characteristics of producers who use farmers' markets as a retailing outlet. In addition, this study aimed to identify educational needs and obstacles as perceived by farmers' market vendors in West Virginia. The objectives also sought to identify specific program objectives for Extension in the educational support of direct-marketing producers in West Virginia.

\section{Research Questions}

The following research questions were used to guide the development of this study:

1. What were the demographics of farmers selling at West Virginia farmers' markets?

2. What products were produced by farmers' market vendors in 2004 ?

3. How many months of the year were farmers able to market products via farmers' markets?

4. What season extension methods were used by growers who sell at West Virginia 
farmers' markets?

5. What promotional and marketing methods were used by vendors at West Virginia farmers' markets?

6. How did vendors believe their prices compared with prices received for products of similar quality at supermarkets?

7. What were the gross sales earned by vendors at farmers' markets?

8. What percentage of the sales derived by vendors at West Virginia farmers' markets was attributable to Women, Infants \& Children (WIC) or Senior Farmers' Market Nutrition Program (FMNP) vouchers?

9. What percent of the vendors' total household income was derived from sales at farmers' markets?

10. What changes did vendors perceive as necessary for overall improvement of farmers' markets?

11. What educational needs did farmers' market vendors identify as potentially helpful?

12. What obstacles did farmers' market vendors perceived as the greatest threat to the future success of farmers' markets in West Virginia?

\section{Research Design}

Using a descriptive research method, data was collected from the target population by means of a 50 item survey. The descriptive method was chosen for its ability to collect a wide scope of information, including both nominal (quantitative) data and written (qualitative) opinions. It can do so, according to Ary, Jacobs and Razavieh, because it aims to ask questions "about the nature, incidence, or distribution of variables; it involves describing but not manipulating variables" (2002, p.558). While the majority of questions were close-ended, items 
pertaining to educational topics and obstacles were more open-ended, lending themselves to qualitative analysis. By eliciting such perceived needs through open-ended questions, it is hoped that qualitative theories "might be developed from which hypotheses could be deduced and subsequently tested by quantitative research" (Patten, 2002, p. 21).

\section{Population}

For the purposes of this study, a farmers' market is defined as a common facility or area where multiple farmers/growers gather on a regular recurring basis to sell a variety of fresh fruits, vegetables, and other farm products directly to customers (Payne, 2002). Markets which function solely as a retail outlet for products sourced from West Virginia agricultural producers (as opposed to producer only markets meeting the definition used in Chapter II, in which government-paid employees serve as managers) generally have different characteristics from other markets and were, therefore, excluded from this study.

The target population consisted of all vendors selling at seasonal farmers' markets in West Virginia in the 2004 season. A census was considered most appropriate for this study in order to minimize potential sampling and selection errors. To ensure that the list of farmers' market vendors was as complete as possible, several methods were used in the creation of the list of target population members. In addition to the list of 150 vegetable growers used by the University Extension Service, vendors were identified by collecting contact information in person at West Virginia farmers' markets as well as from market managers. In order to account for the temporary absences of vendors, lists obtained from market visits were cross-referenced with lists provided from market managers, which were often more complete. The contact information yielded from these methods was in turn cross-referenced with the former list of 150 to eliminate frame error duplications. This resulted in a population of 331. 
Using a census survey method, the researcher included all members of the vendor population regardless of their state of residency. For example, individuals with residences in bordering states were included in the study as long as they used at least one farmers' market in West Virginia as a marketing outlet. Not targeted in the population were agribusinesses residing in West Virginia which use farmers' markets solely located in other states as a marketing outlet. Of the 331 distributed questionnaires, 226 were returned, presenting the researcher with a response rate of $68.3 \%$. Those respondents indicating that they did not sell any products at a West Virginia farmers' market in the 2004 season, or whose business partner had already completed a questionnaire, were removed from subsequent analysis, leaving $183(55.3 \%)$ usable questionnaires.

\section{Instrumentation}

The survey questionnaire was developed by the researcher based on the review of literature (see Appendix A). Content and face validity was established by West Virginia University faculty in Agricultural \& Environmental Education and Agricultural \& Resource Economics and distribution to volunteer vendors as a pilot study. Four pilot group members were recruited from one market which was targeted due to its proximity to the research institution. These individuals met one-on-one and were given the survey in advance of the population at large to allow for adjustments to the instrument.

Reliability of the instrument was determined based on alpha scale analysis of the sample population's data. Cronbach's alpha was valued at .92 and the instrument was deemed to have exemplary reliability (Robinson, Shaver, \& Wrightsman, 1991).

The questionnaire mailed to the population of farmers' market vendors contained questions designed to meet the varied research objectives. Designed into a 8.5" x 7" booklet, the 
survey featured a color cover with a hand-drawn artistic rendering of a produce basket.

Respondents were asked to provide details regarding their participation in one or more West Virginia farmers' market(s). Specifically, items inquired about their promotional efforts, number and seasonal availability of products, pricing, income, and desired directions for market growth. In order to identify the felt needs of respondents, a five-point Likert scale was used for 10 of the items to allow for the prioritizing of Extension efforts they believed would be helpful in support and development of successful farmers' markets $(1=$ Completely unhelpful, $2=$ Not very helpful, $3=$ Slightly helpful, $4=$ Somewhat helpful, and $5=$ Extremely helpful). In all sections of the questionnaire, respondents were encouraged to elaborate on their responses in the margins of the survey booklet. Specifically, vendors were asked to identify educational needs and obstacles to success.

\section{Data Collection Procedures}

Surveys were distributed via the United States Postal Service to each member of the population. Following recommendations by Dillman, each survey was accompanied by a small gift and a hand-signed cover letter (see Appendix B), which explained the purpose of the study and provided directions for completion and return of the questionnaire (Dillman, 2000). Additionally, the respondents were provided with self-addressed stamped envelopes and booklets were numbered to identify non-respondents. Four weeks after the initial mailing, a second mailing of the instrument was sent to non-respondents, accompanied by a new cover letter (see Appendix C).

Ary, Jacobs, and Razavieh (2002) recommend three options "to determine the extent to which respondents differ from the nonrespondents" (p. 408). The researcher of this study compared early respondents to late respondents. Specifically, early and late respondents were 
compared on their yearly production of 72 different products. No significant differences $(\alpha \leq$ .05 ) were found between responses of early and late respondents on the total number of any of the products, including tomatoes, green beans, and cucumbers, which were the most frequently produced. Since differences were not found between early and late respondents, "and late respondents are believed typical of nonrespondents," then the researchers made the assumption that the respondents were "an unbiased sample of the recipients" and thus generalized to the total group (Ary, Jacobs, \& Razavieh, 2002, p. 408).

\section{Analysis of Data}

The objective of the study was to identify the characteristics of farmers' market vendors who sell at farmers' markets in West Virginia. Data were analyzed using the Statistical Package for Social Sciences (SPSS) at West Virginia University, and descriptive statistics were used to analyze data collected from the surveys in the form of frequencies, percentages, and measures of central tendency. Qualitative data on educational topics and perceived obstacles were coded by topic and analyzed in SPSS by frequency.

\section{Use of Findings}

Findings from this study may be used by Extension educators, agricultural economic development specialists, and community developers seeking to create viable marketing outlets as a component of a sustainable local food system. Educators in West Virginia and other states may use this study to better prepare themselves for the educational needs of this growing body of entrepreneurs. By identifying characteristics such as product diversity, season extension, promotional methods and market income, this study may equip educators, market managers, and farmers with some means to predict and plan for sustained farmers' market viability. 


\section{CHAPTER IV}

\section{Findings}

\section{Purpose of the Study}

The purpose of this study was to identify the characteristics of farmers' market vendors in West Virginia. In addition, this study sought to identify the obstacles and educational needs relevant to farmers' market vendors and serve as a tool for the development of educational programming for both producers and consumers. The Extension Service and other community developers can therefore serve a greater role in the further development of farmers' markets as an integral part of sustainable local food systems in West Virginia.

\section{Objectives of the Study}

The objectives of this study were to identify general characteristics, products, promotional strategies, sales levels, season extension methods, and other characteristics of producers who use farmers' markets as a retailing outlet. In addition, this study aimed to identify educational needs and obstacles as perceived by farmers' market vendors in West Virginia. The objectives also sought to identify specific program objectives for Extension in the educational support of direct-marketing producers in West Virginia.

\section{Research Questions}

The following research questions were used to guide the development of this study:

1. What were the demographics of farmers selling at West Virginia farmers' markets?

2. What products were produced by farmers' market vendors in 2004 ?

3. How many months of the year were farmers able to market products via farmers' markets? 
4. What season extension methods were used by growers who sell at West Virginia farmers' markets?

5. What promotional and marketing methods were used by vendors at West Virginia farmers' markets?

6. How did vendors believe their prices compared with prices received for products of similar quality at supermarkets?

7. What were the gross sales earned by vendors at farmers' markets?

8. What percentage of the sales derived by vendors at West Virginia farmers' markets was attributable to Women, Infants \& Children (WIC) or Senior Farmers' Market Nutrition Program (FMNP) vouchers?

9. What percent of the vendors' total household income was derived from sales at farmers' markets?

10. What directions for improvement did vendors perceive as necessary for overall market success?

11. What educational needs did farmers' market vendors identify as potentially helpful?

12. What obstacles did farmers' market vendors perceived as the greatest threat to the future success of farmers' markets in West Virginia?

\section{General Characteristics}

Vendors were asked to provide demographic information including age, gender, state of residence, and highest level of education. The majority of the respondents were over 50 years of age, with $24.6 \%(n=45)$ between 50 and 59. Sixty-eight respondents were split evenly between the two highest age ranges, namely 60 through $69(18.6 \%)$ and over $70(18.6 \%)$. The nine respondents who indicated multiple ages in order to account for both themselves and a partner 
were treated separately and accounted for $4.9 \%$ of the population (see Table 1 ). The median age range was 50 to 59 years.

Table 1

Age of Farmers’ Market Vendors

\begin{tabular}{lcc}
\hline Categories & $\boldsymbol{N}$ & $\%$ \\
\hline Younger than 20 years & 2 & 1.1 \\
20-29 Years & 6 & 3.3 \\
$30-39$ Years & 16 & 8.7 \\
$40-49$ Years & 29 & 15.8 \\
$50-59$ Years & 45 & 24.6 \\
$60-69$ Years & 34 & 18.6 \\
70 Years or More & 34 & 18.6 \\
Partners of Different Ages & 9 & 4.9 \\
Missing value & 8 & 4.4 \\
\hline Total & 183 & 100.0 \\
\hline
\end{tabular}

While the overwhelming majority (82\%) of West Virginia's farmers' market vendors ( $n=$ 150) identified themselves as residents of West Virginia, 18\% were from neighboring states.

Ohio, was home to 16 respondents $(8.7 \%)$, with seven $(3.8 \%)$ and five $(2.7 \%)$ respondents claiming residency in Pennsylvania and Maryland, respectively (see Table 2). 
Table 2

State of Residence of Farmers’ Market Vendors

\begin{tabular}{lcc}
\hline Categories & $\boldsymbol{N}$ & $\%$ \\
\hline West Virginia & 150 & 82.0 \\
Ohio & 16 & 8.7 \\
Pennsylvania & 7 & 3.8 \\
Maryland & 5 & 2.7 \\
Missing value & 5 & 2.7 \\
\hline Total & 183 & 100.0 \\
\hline
\end{tabular}

While more than half of the farmers' market vendors $(n=103,57.9 \%)$ were male, $26.2 \%$ $(n=47)$ were female, and $24(13.1 \%)$ respondents indicated that they were in a partnership with a friend or family member. In order to assess the educational level of farmers' market vendors, survey respondents were asked to identify the highest level of education they had received, from grade school to Doctoral degree. For respondents indicating both the highest education level of themselves and their partner, the highest of the two was recorded. The most common of the nine categories was high school diploma with $31.8 \%(n=55)$ of respondents (see Table 3$)$. The median educational category was Associate's degree/technical degree. Slightly more than 31\% $(n=58)$ had either a college or graduate degree. While level of education was roughly equivalent for males and females, females were more likely to have pursued education beyond a college degree than males. Thirteen of the 47 female respondents $(27.6 \%)$ had some graduate school, a master's degree, or a doctoral degree, compared with $17.5 \%(n=18)$ of male respondents (see Table 3). 
Table 3

Gender and Level of Education

\begin{tabular}{lcccccccc}
\hline & \multicolumn{2}{c}{ Female } & \multicolumn{2}{c}{ Male } & \multicolumn{2}{c}{ Partners } & \multicolumn{2}{c}{ Total } \\
\cline { 2 - 8 } & $N$ & $\%$ & $N$ & $\%$ & $N$ & $\%$ & $N$ & $\%$ \\
\hline Grade School & 4 & 8.5 & 4 & 3.9 & 2 & 8.7 & 10 & 5.8 \\
Some High School & 3 & 6.4 & 10 & 9.7 & 3 & 13.0 & 16 & 9.2 \\
High School Diploma & 15 & 31.9 & 34 & 33.0 & 6 & 26.1 & 55 & 31.8 \\
Associate/Tech. Degree & 2 & 4.3 & 5 & 4.9 & 1 & 4.3 & 8 & 4.3 \\
Some College & 7 & 14.9 & 15 & 14.6 & 4 & 17.4 & 26 & 15.0 \\
College Degree & 3 & 6.4 & 17 & 16.5 & 4 & 17.4 & 24 & 13.9 \\
Some Graduate School & 7 & 14.9 & 6 & 5.8 & 0 & 0.0 & 13 & 7.5 \\
Master's Degree & 5 & 10.6 & 11 & 10.7 & 2 & 8.7 & 18 & 10.4 \\
Doctoral Degree & 1 & 2.1 & 1 & 1.0 & 1 & 4.3 & 3 & 1.7 \\
\hline Total & 47 & 100.0 & 103 & 100.0 & 23 & 100.0 & 173 & 100.0 \\
\hline
\end{tabular}

While farmers' markets were the most commonly used outlet for vendors in 2004, 30 vendors $(16.4 \%)$ indicated that they also sold their products from an on-farm stand. Also popular were marketing outlets such as roadside stands $(14.2 \%)$, wholesaling $(12.6 \%)$, and direct sales to restaurants $(11.5 \%$ ) (see Table 4$)$. In addition to the ranges provided in the survey questionnaire, over $13 \%$ of farmers' market vendors specified other marketing methods that were utilized in the sale of their products in 2004. Most common among these outlets were individual sales made to neighbors, friends, or relatives. Respondents with specialty items like cut flowers indicated they also made arrangements for weddings and other special events. 
Table 4

Location of Sales in 2004

\begin{tabular}{lcc}
\hline Categories & N & $\%$ \\
\hline Farmers' Markets & 177 & 96.7 \\
On-Farm Stand & 30 & 16.4 \\
Roadside Stand & 26 & 14.2 \\
Wholesale to Stores/Markets & 23 & 12.6 \\
To Restaurants & 21 & 11.5 \\
Flea Markets & 13 & 7.1 \\
Pick-Your-Own & 11 & 6.0 \\
Subscription or Community Supported Agriculture & 7 & 3.8 \\
Catalogue/Mail Order & 1 & .5 \\
Did Not Sell in 2004 & 1 & .5 \\
Internet & 24 & 13.1 \\
Other & 32 & 0.0 \\
Sold at a Farmers' Market Outside of West Virginia & 0 & .5 \\
\hline
\end{tabular}

Vendors were asked if, in addition to selling at a West Virginia farmers' market in 2004, they had also sold their products at a farmers' market in another state. Nearly $18 \%(n=32)$ indicated that they had vended in a state other than West Virginia (see Table 4). The breakdown by state was Maryland $(n=12)$, Pennsylvania $(n=7)$, Virginia $(n=6)$, Kentucky $(n=5)$, and Ohio $(n=4)$.

The level of attendance at farmers' markets varied from zero to ten different markets, though the average number was 1.61 markets with a standard deviation of 1.30 . The average 
vendor attended a market at least two days of the week during peak season of $2004(M=2.42)$, with a standard deviation of 1.81 (see Table 5).

Table 5

Summary of Farmers’'Market Attendance

\begin{tabular}{lcccccc}
\hline Categories & $\boldsymbol{N}$ & Min & Max & $\boldsymbol{M}$ & Mode & $\boldsymbol{S D}$ \\
\hline Number of Farmers' Markets Attended & 182 & 0 & 10 & 1.61 & 1 & 1.30 \\
Days of the Week at Farmers' Markets & 183 & 0 & 7 & 2.42 & 1 & 1.81 \\
\hline
\end{tabular}

In an effort to determine how closely farmers' markets are located to the producers, vendors were asked how far they traveled one-way to their main market. The most frequently reported category was $10-19$ miles. Nearly $40 \%$ of respondents $(n=67)$, however, reported traveling 20 miles or more, and ten vendors (5.5\%) traveled 50 miles or more (see Table 6).

\section{Products}

In order to develop a thorough understanding of the types of products vendors are choosing to produce throughout the year, they were asked to fill in a two page matrix which divided products into seven categories, the most extensive of which was vegetables. The other categories included fruits, dairy \& eggs, meat products, live plants, cut flowers \& herbs, and processed products, all of which contained a list of products frequently sold at farmers' markets and/or typically produced by agricultural enterprises in the region. In addition to checking off the months in which they had produced certain products, they were also asked to indicate the months in which they produced other items not specifically listed under a given category. If a 
Table 6

Distance to Main Market

\begin{tabular}{lcc}
\hline Categories & $\boldsymbol{N}$ & $\%$ \\
\hline $0-9$ Miles & 49 & 26.7 \\
10-19 Miles & 62 & 33.9 \\
$20-29$ Miles & 31 & 19.1 \\
$30-39$ Miles & 17 & 9.3 \\
$40-49$ Miles & 9 & 4.9 \\
50 Miles or More & 10 & 5.5 \\
Missing value & 1 & .5 \\
\hline Total & 183 & 100.0 \\
\hline
\end{tabular}

product was produced and sold as organic, respondents were asked to indicate so within the matrix. In analyzing the data, each vendor was assigned a ' 1 ' for each month in which a product was produced, and a ' 0 ' for each month in which a product was not produced. Combined totals are based on the sums of each ' 1 ' in a given month (column), as well as each given product (row). Means were calculated to represent the average number of products in the category produced by each vendor in a given month, and were based on the total population of respondents $(n=183)$. Appendix $\mathrm{D}$ has a complete breakdown of products and frequencies, combined totals by product and month, as well as products which one or more vendors sold as organic.

Vegetables were the most frequently represented category, particularly for the summer months. The instrument provided 31 types of vegetables, in addition to an 'Other' category. In this category, tomatoes, green beans, and cucumbers were the most commonly produced 
vegetables throughout the year, with the average vendor producing them for 2.55 months $(S D=1.86), 2.24$ months $(S D=1.82)$, and 2.06 months $(S D=1.84)$ respectively. The month with the greatest diversity of vegetables was August, with the average vendor producing over six different types of vegetables. In this month, a combined total of 1129 products were produced by the vendors (see Table 7). September and November, however, both yielded the widest ranges of products, with some vendors producing 20 different types of vegetables (see Table 7). With the exception of celery and okra, all of the vegetable categories were produced organically by at least one vendor at some point throughout the year. In terms of season extension, vegetables were the items least produced in the winter months. In both January and February, only two of 183 vendors produced any fresh vegetable products at all.

Table 7

Vegetable Production by Month

\begin{tabular}{lcccccc}
\hline & $\boldsymbol{N}$ & Min & Max & $\boldsymbol{M}$ & SD & Total \\
\hline January & 183 & .00 & 2.00 & .020 & .092 & 3 \\
February & 183 & .00 & 2.00 & .022 & .180 & 4 \\
March & 183 & .00 & 4.00 & .098 & .525 & 18 \\
April & 183 & .00 & 11.00 & .295 & 1.177 & 54 \\
May & 183 & .00 & 15.00 & .760 & 1.874 & 139 \\
June & 183 & .00 & 15.00 & 2.956 & 3.545 & 540 \\
July & 183 & .00 & 17.00 & 5.716 & 4.523 & 1046 \\
August & 183 & .00 & 19.00 & 6.170 & 4.855 & 1129 \\
September & 183 & .00 & 20.00 & 5.776 & 5.252 & 1057 \\
October & 183 & .00 & 19.00 & 3.197 & 4.509 & 583 \\
November & 183 & .00 & 20.00 & .415 & 1.840 & 76 \\
December & 183 & .00 & 5.00 & .055 & .416 & 10 \\
\hline
\end{tabular}


Included in the dairy and egg category were milk, cheese, eggs, and yogurt. Among these, eggs were the most common products, with the average vendor producing for more than one month of the year $(\mathrm{M}=1.06, \mathrm{SD}=3.16)$ and twelve vendors producing year-round (see Appendix F). While organic eggs were available every month of the year, there were no other organic products reported in the dairy and eggs category. The months in which the greatest number of vendors reported some type of dairy and eggs produced were June, July, and August (see Table 8). None of the vendors reported the production for sale of milk or yogurt, though four vendors produced cheese at least part of the year.

Table 8

Dairy and Egg Production by Month

\begin{tabular}{lcccccc}
\hline & $\boldsymbol{N}$ & Min & Max & $\boldsymbol{M}$ & SD & Total \\
\hline January & 183 & .00 & 1.00 & .066 & .248 & 12 \\
February & 183 & .00 & 1.00 & .066 & .248 & 12 \\
March & 183 & .00 & 1.00 & .066 & .248 & 12 \\
April & 183 & .00 & 1.00 & .082 & .275 & 15 \\
May & 183 & .00 & 2.00 & .126 & .393 & 21 \\
June & 183 & .00 & 2.00 & .148 & .413 & 25 \\
July & 183 & .00 & 2.00 & .148 & .413 & 25 \\
August & 183 & .00 & 2.00 & .148 & .413 & 25 \\
September & 183 & .00 & 2.00 & .137 & .390 & 24 \\
October & 183 & .00 & 2.00 & .115 & .352 & 21 \\
November & 183 & .00 & 2.00 & .104 & .340 & 19 \\
December & 183 & .00 & 2.00 & .077 & .286 & 14 \\
\hline
\end{tabular}


Among the meat sub-categories were beef, poultry, and pork. Both lamb and rabbit appeared in the 'Other' category. Though only two vendors raised poultry, it was the only meat category with organic producers. In October, there were 14 meat products available and in February the maximum number of meat products was two (see Table 9). Beef was the only meat available from a vendor on a year-round basis and no one produced more than three kinds of meat products in a given month.

Table 9

Meat Product Production by Month

\begin{tabular}{lcccccc}
\hline & $\boldsymbol{N}$ & $\boldsymbol{M i n}$ & $\boldsymbol{M a x}$ & $\boldsymbol{M}$ & $\boldsymbol{S D}$ & Total \\
\hline January & 183 & .00 & 3.00 & .038 & .265 & 7 \\
February & 183 & .00 & 2.00 & .033 & .207 & 6 \\
March & 183 & .00 & 1.00 & .027 & .163 & 5 \\
April & 183 & .00 & 2.00 & .038 & .219 & 7 \\
May & 183 & .00 & 2.00 & .038 & .219 & 7 \\
June & 183 & .00 & 2.00 & .038 & .219 & 7 \\
July & 183 & .00 & 2.00 & .038 & .219 & 7 \\
August & 183 & .00 & 2.00 & .038 & .219 & 7 \\
September & 183 & .00 & 2.00 & .049 & .241 & 9 \\
October & 183 & .00 & 2.00 & .077 & .323 & 14 \\
November & 183 & .00 & 2.00 & .049 & .266 & 9 \\
December & 183 & .00 & 3.00 & .049 & .302 & 9 \\
\hline
\end{tabular}

The live plant category included annuals, perennials, bedding plants, and an 'Other' category which allowed for the inclusion of Christmas trees, shrubs, and other items vendors perceived as separate from the given sub-categories. Unlike fruits and vegetables, live plants 
were produced most abundantly in the spring months and less commonly as the season progressed (see Table 10). June was the most popular month for live plant production with a combined total of 105 product offerings, with the average vendor producing .574 live plant products in that month $(M=.574)$. Live plant production was year-round and both annuals and perennials were produced organically between April and October (see Appendix F).

Table 10

Live Plant Production by Month

\begin{tabular}{lcccccc}
\hline & $\boldsymbol{N}$ & Min & Max & $\boldsymbol{M}$ & SD & Total \\
\hline January & 183 & .00 & 3.00 & .049 & .319 & 9 \\
February & 183 & .00 & 3.00 & .049 & .319 & 9 \\
March & 183 & .00 & 4.00 & .104 & .530 & 19 \\
April & 183 & .00 & 4.00 & .383 & .964 & 70 \\
May & 183 & .00 & 4.00 & .557 & 1.092 & 102 \\
June & 183 & .00 & 4.00 & .574 & 1.091 & 105 \\
July & 183 & .00 & 4.00 & .372 & .910 & 68 \\
August & 183 & .00 & 4.00 & .246 & .734 & 45 \\
September & 183 & .00 & 4.00 & .229 & .728 & 42 \\
October & 183 & .00 & 4.00 & .148 & .570 & 27 \\
November & 183 & .00 & 2.00 & .055 & .291 & 10 \\
December & 183 & .00 & 2.00 & .049 & .263 & 9 \\
\hline
\end{tabular}

The product matrix included eight categories of fruits and nuts, in addition to an 'Other' category. August, July, and September were the months (in descending order) in which the average vendor reported production of fruits (see Table 11). While the total number of fruits produced was highest in July, September saw the widest range of product diversity $($ Max $=5)$ 
with a total of 80 fruit and nut products produced in July (see Table 11). Tree fruit production was most common with the average vendor producing one or more tree fruit crop for .42 months of the year $(S D=1.14)$. Tree fruits, bramble fruits, and strawberries were the most commonly produced. There were no vendors reporting production of fruit year-round. Bramble fruits, blueberries, papaws and other tree fruits were produced organically by at least one vendor (see Appendix F).

Table 11

Fruit and Nut Production by Month

\begin{tabular}{lcccccc}
\hline & $\boldsymbol{N}$ & Min & Max & $\boldsymbol{M}$ & $\boldsymbol{S D}$ & Total \\
\hline January & 183 & .00 & .00 & .000 & .000 & 0 \\
February & 183 & .00 & .00 & .000 & .000 & 0 \\
March & 183 & .00 & .00 & .000 & .000 & 0 \\
April & 183 & .00 & .00 & .000 & .000 & 0 \\
May & 183 & .00 & 1.00 & .060 & .239 & 0 \\
June & 183 & .00 & 3.00 & .198 & .530 & 29 \\
July & 183 & .00 & 4.00 & .363 & .721 & 80 \\
August & 183 & .00 & 4.00 & .390 & .726 & 73 \\
September & 183 & .00 & 5.00 & .340 & .709 & 63 \\
October & 183 & .00 & 3.00 & .187 & .513 & 34 \\
November & 183 & .00 & 2.00 & .016 & .165 & 5 \\
December & 183 & .00 & 1.00 & .005 & .074 & 4 \\
\hline
\end{tabular}

The product matrix provided in the instrument grouped herbs and cut flowers in the same general category without dividing products by species. Herb production was more common than the production of cut flowers. Herbs were produced for 12 months of the year and cut flowers 
for eight months. July and August were the two months in which there was the highest level of herb and cut flower production, both with a product mean of $.246(S D=.502$ and .513 respectively) (see Table 12). Both herbs and flowers were produced organically by at least one vendor throughout the spring and summer months (see Appendix F).

Table 12

Herb \& Cut Flower Production by Month

\begin{tabular}{lcccccc}
\hline & $\boldsymbol{N}$ & $\boldsymbol{M i n}$ & $\boldsymbol{M a x}$ & $\boldsymbol{M}$ & $\boldsymbol{S D}$ & Total \\
\hline January & 183 & .00 & 1.00 & .016 & .127 & 3 \\
February & 183 & .00 & 1.00 & .016 & .127 & 3 \\
March & 183 & .00 & 1.00 & .016 & .127 & 3 \\
April & 183 & .00 & 1.00 & .077 & .267 & 11 \\
May & 183 & .00 & 2.00 & .175 & .409 & 32 \\
June & 183 & .00 & 2.00 & .235 & .485 & 43 \\
July & 183 & .00 & 2.00 & .246 & .502 & 46 \\
August & 183 & .00 & 2.00 & .246 & .513 & 45 \\
September & 183 & .00 & 2.00 & .213 & .473 & 39 \\
October & 183 & .00 & 2.00 & .148 & .399 & 27 \\
November & 183 & .00 & 2.00 & .027 & .194 & 5 \\
December & 183 & .00 & 1.00 & .011 & .104 & 2 \\
\hline
\end{tabular}

As value-added products have the potential to extend what could otherwise be a short season, this study inquired about the availability of processed products from farmers' market vendors. Included in this category were baked goods, cider, condiments, honey, jams/preserves, salad dressings, soaps, wool, and an 'Other' sub-category, which included items like maple syrup and wood products. The category most frequently represented and produced year-round by 
several vendors was baked goods. August and September were the two months in which processed products were produced by the greatest number of vendors. September had a total of 73 processed products (see Table 13). Between May and August there was at least one respondent producing something from six of the eleven sub-categories.

Table 13

Processed Product Production by Month

\begin{tabular}{lcccccc}
\hline & $\boldsymbol{N}$ & $\boldsymbol{M i n}$ & $\boldsymbol{M a x}$ & $\boldsymbol{M}$ & $\boldsymbol{S D}$ & Total \\
\hline January & 183 & .00 & 2.00 & .087 & .336 & 16 \\
February & 183 & .00 & 2.00 & .087 & .336 & 15 \\
March & 183 & .00 & 2.00 & .087 & .336 & 16 \\
April & 183 & .00 & 4.00 & .159 & .557 & 29 \\
May & 183 & .00 & 6.00 & .257 & .745 & 47 \\
June & 183 & .00 & 6.00 & .333 & .821 & 61 \\
July & 183 & .00 & 6.00 & .383 & .849 & 70 \\
August & 183 & .00 & 6.00 & .393 & .857 & 72 \\
September & 183 & .00 & 5.00 & .399 & .825 & 73 \\
October & 183 & .00 & 5.00 & .350 & .850 & 65 \\
November & 183 & .00 & 5.00 & .224 & .741 & 41 \\
December & 183 & .00 & 5.00 & .164 & .625 & 30 \\
\hline
\end{tabular}

In order to gain an understanding of how vendors perceive product diversity and their future involvement at the farmers market, they were asked whether they planned on offering more, fewer, or the same number of products in the following season. While nearly half of all respondents $(n=87)$ planned to offer the same number of products in 2005 as they did in 2004, nearly as many $(n=77)$ planned to expand the number of products for sale in 2005 . Less than 
$10 \%(n=18)$ indicated that they plan to offer fewer products for sale at farmers' markets. This included those who specifically indicated they would not sell at farmers' markets in West Virginia during the 2005 season.

Table 14

Projected Product Offerings for Next Season

\begin{tabular}{lcc}
\hline Categories & $\boldsymbol{N}$ & $\boldsymbol{\%}$ \\
\hline Fewer Products & 18 & 9.8 \\
More Products & 77 & 42.1 \\
Same Number of products & 87 & 47.5 \\
Missing value & 1 & .5 \\
\hline Total & 183 & 100.0 \\
\hline
\end{tabular}

Length of Season

While the product matrix sought to elicit specific information on what was being produced at certain points of the year, the study also sought to learn how adequate vendors perceived farmers' markets to be in providing them with a sales outlet suitable to their production season. In order to determine the number of months in a given season that vendors are using farmers' markets as sales outlets, they were asked how many weeks they sold products at a West Virginia farmers' market. While the most frequently reported category was 5-8 weeks, the median range of attendance at West Virginia farmers' markets in 2004 was 9-12 weeks. This means that slightly over half of farmers' market vendors in West Virginia used markets as a sales outlet for 3 months or less (see Table 15). 
Table 15

Weeks at Farmers' Market in 2004

\begin{tabular}{lcc}
\hline Categories & $\boldsymbol{N}$ & $\mathbf{\%}$ \\
\hline $1-4$ Weeks & 10 & 5.5 \\
$5-8$ Weeks & 49 & 26.8 \\
$9-12$ Weeks & 35 & 19.1 \\
$13-16$ Weeks & 28 & 15.3 \\
$17-20$ Weeks & 19 & 10.4 \\
21 or More Weeks & 40 & 21.9 \\
Missing value & 2 & 1.1 \\
\hline Total & 183 & 100.0 \\
\hline
\end{tabular}

While more than half of farmers' market vendors claim to use no season extension methods $(n=95,51.9 \%), 24 \%$ of the respondents $(n=44)$ reported using a greenhouse or hoophouse. Row covers served as the second most common method ( $n=33,18 \%$ ), and 12\% $(n=22)$ of vendors extended their marketing season by preserving products for later sale (see Table 16). Methods of doing so included dehydrating, freezing, making preserves, or other types processing. Season extension methods mentioned in the 'Other' category include succession planting $(n=2)$ and prayer $(n=2)$, as well as using heat lights, cold frames, and mulching. 
Table 16

Season Extension Methods Used by Farmers’'Market Vendors

\begin{tabular}{lcc}
\hline Categories & $\boldsymbol{N}$ & $\boldsymbol{\%}$ \\
\hline No Season Extension & 95 & 51.9 \\
Greenhouse/Hoophouse & 44 & 24.0 \\
Row Covers & 33 & 18.0 \\
Preserving for Later Sale & 22 & 12.0 \\
Cold Storage & 14 & 7.7 \\
High Tunnels & 11 & 6.0 \\
Other Season Extension & 12 & 6.6 \\
\hline
\end{tabular}

In an effort to understand the degree to which vendors believe their market seasons are sufficient to match the length of their production season, they were asked what they felt were the ideal starting and ending times for the farmers' market season. In other words, would they prefer to start the season at their main market earlier, later, or at the same time as it currently opens? Conversely, would they prefer the market season end earlier, later, or at the same time as it currently ends? In answering both questions, more than half seemed satisfied with the current opening and closing dates, though people apparently felt less satisfied with the opening date (see Table 17). Thirty-three percent $(n=61)$ felt that the farmers' market should begin earlier in the spring/summer, while only four respondents $(2.2 \%)$ wanted the market to begin later in the season. Though $74.9 \%$ of vendors $(n=137)$ felt that the ideal ending market season would end at roughly the same time as their market currently ends, over $20 \%(n=38)$ thought the market should stay open later in the season than it currently does. 
Table 17

Ideal Farmers’ Market Starting and Ending Times

\begin{tabular}{lcccc}
\hline & \multicolumn{2}{c}{ Ideal Start of Market Season } & \multicolumn{2}{c}{ Ideal End of Market Season } \\
\cline { 2 - 5 } & $\boldsymbol{N}$ & $\%$ & $\mathbf{N}$ & $\mathbf{\%}$ \\
\cline { 2 - 5 } Earlier & 61 & 33.3 & 38 & 20.8 \\
Later & 4 & 2.2 & 137 & 74.9 \\
Same Time & 116 & 63.4 & 3 & 1.6 \\
Missing value & 2 & 1.1 & 183 & 100.0 \\
\hline Total & 183 & 100.0 & & \\
\hline
\end{tabular}

Promotional and Advertising Methods at Farmers’'Markets

Three questions on the survey instrument were designed to gather information on the methods commonly used by vendors to promote, label, and advertise their products at market. The most frequent method used to promote sales was by giving free samples, as $38.8 \%(n=71)$ of the vendors indicated that they had done so at some point in the 2004 season (see Table 18). Similarly, 33.9\% $(n=62)$ used bulk discounts as a means to promote sales. Over a quarter of the respondents $(n=46)$ indicated that they offered lower quality or canning produce at a reduced rate.

Many vendors also indicated that they used other methods not mentioned on the instrument, including using creative displays or signage $(n=6,3.3 \%)$, establishing a set price and not offering special deals $(n=6,3.3 \%)$, offering consistently high quality $(n=5,2.7 \%)$, and good salesmanship $(n=4,2.2 \%)$. 
Table 18

Promotional Strategies Used by Farmers' Market Vendors

\begin{tabular}{lll}
\hline Categories & $\boldsymbol{N}$ & $\boldsymbol{\%}$ \\
\hline Free Samples/Tastings & 71 & 38.8 \\
Bulk Discounts & 62 & 33.9 \\
Seconds/Canning Quality at Reduced Price & 46 & 25.1 \\
Bargaining & 34 & 18.6 \\
Buy a Certain Number, Get One Free & 29 & 15.8 \\
Combination Into a Package & 21 & 11.5 \\
Other Promotions & 38 & 20.8 \\
\hline
\end{tabular}

Because the words used to describe one's products can have a significant impact on promotion, vendors were asked what terms they used in labeling their products at West Virginia farmers' markets. The most commonly used terms were 'home grown' $(n=116,63.4 \%)$, 'fresh' ( $n=98,53.6 \%)$, 'family farm' $(n=67,36.3 \%)$, 'natural' $(n=36,19.7 \%)$ 'chemical-free' $(n=$ $23,12.6 \%)$ and 'heirloom' $(n=20,10.9 \%)$ (see Table 19).

Over ten percent of respondents also indicated they used other terms when labeling their products. These include 'organic' (not certified) or 'insecticide-free' $(4.9 \%, n=9)$, 'West Virginia Grown,' ( $n=3,1.6 \%)$ and 'Home-made' $(n=3,1.6 \%)$. 
Table 19

Terms Used to Label Products at Farmers’ Markets

\begin{tabular}{lcc}
\hline Categories & $\boldsymbol{N}$ & $\%$ \\
\hline 'Home Grown' & 116 & 63.4 \\
'Fresh' & 98 & 53.6 \\
'Family Farm' & 67 & 36.6 \\
'Natural' & 36 & 19.7 \\
'Chemical-free' & 23 & 12.6 \\
'Heirloom' & 20 & 10.9 \\
'Hand-made' & 11 & 6.0 \\
'Free-range' & 10 & 5.5 \\
'Certified Organic' & 4 & 2.2 \\
'Grass-fed' & 3 & 1.6 \\
Other Terms & 19 & 10.4 \\
\hline Total & 183 & 100.0 \\
\hline
\end{tabular}

Vendors were also asked to indicate which methods they had used in 2004 to advertise their business (see Table 20). The most common methods were business cards $(n=63,34.4 \%)$, recipes $(n=39,21.3 \%)$, photos of their farm or facility $(n=27,14.8 \%)$, and brochures $(n=19$, 10.4\%) (see Table 20).

Many respondents $(n=48,26.2 \%)$ offered other methods which they had used to convey information to customers and potential customers at market. The most prevalent form of communication mentioned by respondents in the 'other' category was some form of one-on-one verbal communication with customers at market $(n=22)$, with nine vendors $(4.9 \%)$ mentioning 
word-of-mouth advertising. Other methods of providing information to customers include handmade signs or information cards $(n=4)$, conducting farm/garden tours $(n=3)$, giving recipes verbally $(n=3)$, and having information printed on either the display or delivery truck $(n=2)$.

Table 20

Means of Communicating with Customers at Farmers' Markets

\begin{tabular}{lll}
\hline Categories & N
\end{tabular}

\begin{tabular}{lcc}
\hline Business Cards & 63 & 34.4 \\
Recipes & 39 & 21.3 \\
Photos of Farm or Facility & 27 & 14.8 \\
Brochures & 19 & 10.4 \\
Newsletter Mailing List & 9 & 4.9 \\
Web Site & 8 & 4.4 \\
Email Lists & 4 & 2.2 \\
Other Communication & 48 & 26.2
\end{tabular}

Vendors were asked whether or not they possessed liability insurance to cover their participation at farmers' markets. Nearly one quarter of respondents $(n=43,23.5 \%)$ have their own liability insurance policy which covered their participation at farmers' markets. More than half $(n=103,56.3 \%)$ were not covered by any sort of liability insurance policy that would provide coverage in the event that someone should be sick or injured as a result of their product or their set-up (see Table 21$)$. Almost $10 \%(n=18)$ did not have a policy specifically drawn for their business, but were covered by an umbrella policy through the farmers' market. Sixteen vendors $(8.7 \%)$ did not know if they were covered by a liability insurance policy or not. 
Table 21

Product Liability Insurance

\begin{tabular}{lcc}
\hline Categories & N & \% \\
\hline No & 103 & 56.3 \\
Yes & 43 & 23.5 \\
I don't know & 16 & 8.7 \\
No, but have coverage with the market & 18 & 9.8 \\
Missing & 3 & 1.6 \\
\hline Total & & 100.0 \\
\hline
\end{tabular}

To gain information on what aspects of the farmers' markets attended were in need of the most change, vendors were provided with nine characteristics and asked whether they think these characteristics should increase, decrease, or stay the same. Of the nine, advertising was considered the most important, with slightly more than $60 \%$ of respondents $(n=110)$ indicating a need to increase advertising (see Table 22). The category least in need of change was market hours of operation, as $72.1 \%(n=132)$ of the vendors perceived no necessary change. The only category which more than $10 \%$ of the respondents felt a need to decrease was the number of nonproduce vendors, with 21 vendors $(11.5 \%)$ in favor of a decrease. A small percentage $(n=16$, $8.7 \%$ ) indicated a need to increase dues or fees required to sell at the market. Other categories which commanded an increase were overall product diversity $(n=77,42.1 \%)$, the number of produce vendors $(n=70,38.3 \%)$, and enforcement of market rules $(n=56,30.6 \%)$. The category with the highest standard deviation was 'number of non-produce vendors,' indicating 
that there is a high degree of variability $(S D=.653)$ on whether or not more non-produce items are needed at West Virginia's farmers' markets.

Table 22

Summary of Directions of Change Desired by Farmers’ Market Vendors

\begin{tabular}{|c|c|c|c|c|c|c|c|c|c|}
\hline \multirow[b]{2}{*}{ Categories } & \multicolumn{2}{|c|}{ Decrease } & \multicolumn{2}{|c|}{ The same } & \multicolumn{2}{|c|}{ Increase } & \multirow[b]{2}{*}{ Total } & \multirow[b]{2}{*}{$M$} & \multirow[b]{2}{*}{$S D$} \\
\hline & $N$ & $\%$ & $N$ & $\%$ & $N$ & $\%$ & & & \\
\hline Advertising & 1 & .5 & 53 & 29.0 & 110 & 60.1 & 164 & 2.66 & .485 \\
\hline Overall product diversity & 1 & .5 & 77 & 42.1 & 77 & 42.1 & 155 & 2.49 & .514 \\
\hline \# of produce vendors & 6 & 3.3 & 80 & 43.7 & 70 & 38.3 & 156 & 2.41 & .567 \\
\hline $\begin{array}{l}\text { Enforcement of market } \\
\text { rules }\end{array}$ & 7 & 3.8 & 101 & 55.2 & 56 & 30.6 & 164 & 2.30 & .545 \\
\hline Length of market season & 1 & .5 & 121 & 66.1 & 41 & 22.4 & 163 & 2.25 & .446 \\
\hline Days of the week open & 3 & 1.6 & 117 & 63.9 & 40 & 21.9 & 160 & 2.23 & .465 \\
\hline \# of non-produce vendors & 21 & 11.5 & 84 & 45.9 & 50 & 27.3 & 155 & 2.19 & .653 \\
\hline Market hours of operation & 4 & 2.2 & 132 & 72.1 & 29 & 15.8 & 165 & 2.15 & .422 \\
\hline Membership dues & 16 & 8.7 & 125 & 68.3 & 16 & 8.7 & 157 & 2.0 & .453 \\
\hline
\end{tabular}

Pricing Methods

When asked to indicate how they perceived their prices ranked against prices charged for products of similar quality at grocery stores, the majority of respondents $(n=100)$ felt that their prices were either significantly or somewhat lower. Overall, the most common category represented was 'significantly lower,' reported by $32.8 \%(n=60)$ of the respondents (see Table 23). More vendors tended to perceive their products as 'about the same' as grocery store prices $(n=36,19.7 \%)$ than as either 'somewhat higher' $(n=28,15.3 \%)$ or 'significantly higher' $(n=3$, 
$1.6 \%)$ than grocery store prices. Nearly $8 \%(n=14)$ of those surveyed indicated they did not know how their prices compared with those at grocery stores. The median category was 'somewhat lower,' with a standard deviation of 1.61. Less than $20 \%(n=31)$ of respondents perceived their prices to be higher than those charged at grocery stores for the same products of similar quality (see Table 23).

Table 23

Farmers’ Market Prices Compared to Grocery Store Prices

\begin{tabular}{lll}
\hline Categories & $\boldsymbol{N}$ & $\%$ \\
\hline Significantly lower & 40 & 21.8 \\
Somewhat lower & 60 & 32.8 \\
About the same & 36 & 19.7 \\
Somewhat higher & 28 & 15.3 \\
Significantly higher & 3 & 1.6 \\
Don't know & 14 & 7.7 \\
Missing value & 2 & 1.1 \\
\hline Total & 183 & 100.0 \\
\hline
\end{tabular}

Respondents were also asked what general principles they used when establishing prices for their products. The most common practice ( $n=105,57.4 \%$ ) was comparison with other vendors at the market (see Table 24). Sixty-one respondents (33.3\%) developed prices by calculating their cost of production plus profit margin and $25.7 \%(n=47)$ indicated that, as a general rule, they set their prices below the grocery store price for similar products. Respondents indicating that they used other methods instead of or in addition to the provided categories $(n=$ 15, 8.2\%) specifically mentioned several techniques. These included using the prices established 
for them by market management, determining what price they would be willing to pay for a given product, and the general extent of demand for a given product.

Table 24

Methods of Establishing Prices at Farmers’ Markets

\begin{tabular}{lcc}
\multicolumn{1}{c}{ Categories } & $\boldsymbol{N}$ & $\%$ \\
\hline Above grocery store prices & 16 & 8.7 \\
Below grocery store prices & 47 & 25.7 \\
Same as grocery store prices & 31 & 16.9 \\
Comparison with other vendors & 105 & 57.4 \\
Cost of production plus profit margin & 61 & 33.3 \\
Other & 15 & 8.2 \\
\hline
\end{tabular}

\section{Sales Levels and Income}

Two questions in the instrument were designed to gather information on the actual sales values obtained from farmers' markets in 2004. Firstly, vendors were asked about their sales levels on a given market day in the peak of the season. Nearly $50 \%$ of the vendors $(n=90)$ claimed that their average daily sales per market amounted to $\$ 199$ or less, with $23 \%(n=42)$ selling \$200-\$399 in products (see Table 25). The median range category was $\$ 200$ to $\$ 399$ in sales on an average market day in the peak of the season. Six of the vendors $(3.3 \%)$ had average daily sales of $\$ 2,000$ or more. 
Table 25

Average Daily Sales per Farmers’'Market in 2004

\begin{tabular}{lcc}
\hline Categories & $\boldsymbol{N}$ & $\%$ \\
\hline$\$ 199$ or less & 90 & 49.2 \\
$\$ 200-\$ 399$ & 42 & 23.0 \\
$\$ 400-\$ 599$ & 15 & 8.2 \\
$\$ 600-\$ 799$ & 9 & 4.9 \\
$\$ 800-\$ 999$ & 5 & 2.7 \\
$\$ 1,000-\$ 1,199$ & 6 & 3.3 \\
$\$ 1,200-\$ 1,399$ & 1 & .5 \\
$\$ 1,400-\$ 1,599$ & 1 & .5 \\
$\$ 2,000$ or more & 6 & 3.3 \\
Missing value & 8 & 4.4 \\
\hline Total & 183 & 100.0 \\
\hline
\end{tabular}

In addition to average sales per market day, vendors were asked to provide information on their total amount of sales derived from farmers' markets in the 2004 season. The median level of sales was in the range of $\$ 1,500$ to $\$ 2,999$ with $11.8 \%(n=20)$ of the vendors reporting farmers' market sales in that interval (see Table 26). While the most frequently reported total sales category $(n=69,40.6 \%)$ was $\$ 1,499$ or less, there were 16 vendors $(9.4 \%)$ in the highest annual sales category, of farmers' market sales at $\$ 30,000$ or more in 2004. In the same season, slightly over ten percent $(n=18)$ of the vendors sold between $\$ 4,500$ and $\$ 5,999$ at farmers' markets. 
This sales information was examined along with the overall level of satisfaction with profit margins. The question addressing this was formulated as a ranking system which included the following categories: Very Satisfied, Somewhat Satisfied, Somewhat Unsatisfied, and Very Unsatisfied. The most frequently reported level of satisfaction was 'somewhat satisfied,' reported by exactly half of the respondents $(n=85)$, and just under $30 \%(n=49)$ of the vendors were 'very satisfied' with the profit margin earned from farmers' market sales. On a percentage basis, more of the vendors in the $\$ 1,499$ or less category claimed to be 'somewhat satisfied' ( $n=$ $31,44.9 \%)$ with their profit margin, and more claimed to be 'very satisfied' $(n=20,29 \%)$ than 'very unsatisfied' ( $n=11,15.9 \%)$. In fact, they only other sales categories representing any vendors who were 'very unsatisfied' were $\$ 30,000$ or more $(n=2,12.5 \%)$ and $\$ 9,000-\$ 10,499$ $(n=1,20 \%)$ (see Table 26). Nevertheless, of the 16 vendors making sales of $\$ 30,000$ or more, nearly half ( $n=7,43.8 \%)$ considered themselves 'very satisfied' with their profit margins at farmers' markets.

To put these sales figures in context, vendors were asked what proportion of their total operation and total household incomes were derived from farmers' market sales. For a quarter of the vendors $(n=46)$, farmers' market sales represent $10 \%$ or less of their total business' income. The second most frequently reported category was at the other end of the spectrum with 26 vendors (14.2\%) reporting market sales being $91-100 \%$ of their total business' income (see Table 27). For these vendors, farmers' markets represent the main or sole marketing outlet for their agricultural products. The third most common category $(n=21,11.5 \%)$ fell in the middle of the spectrum, in the range of $41-50 \%$ of total income from the business operation (see Table 27). This category also represented the median category. 
Table 26

Total Farmers' Market Sales in 2004 and Level of Satisfaction with Profit Margin

Satisfaction with profit margin

\begin{tabular}{ccccc}
\hline Very & Somewhat & Somewhat & Very & Total \\
Satisfied & Satisfied & Unsatisfied & Unsatisfied &
\end{tabular}

\begin{tabular}{|c|c|c|c|c|c|c|c|c|c|c|}
\hline Sales Categories & $N$ & $\%$ & $N$ & $\%$ & $N$ & $\%$ & $N$ & $\%$ & $N$ & $\%$ \\
\hline$\$ 1,499$ or less & 20 & 29.0 & 31 & 44.9 & 7 & 10.1 & 11 & 15.9 & 69 & 40.6 \\
\hline$\$ 1,500-\$ 2,999$ & 6 & 30.0 & 12 & 60.0 & 2 & 10.0 & 0 & 0.0 & 20 & 11.8 \\
\hline$\$ 3,000-\$ 4,499$ & 2 & 22.2 & 6 & 66.7 & 1 & 11.1 & 0 & 0.0 & 9 & 5.3 \\
\hline$\$ 4,500-\$ 5,999$ & 6 & 33.3 & 10 & 55.6 & 2 & 11.1 & 0 & 0.0 & 18 & 10.6 \\
\hline$\$ 6,000-\$ 7,499$ & 1 & 9.1 & 9 & 81.8 & 1 & 9.1 & 0 & 0.0 & 11 & 6.5 \\
\hline$\$ 7,500-\$ 8,999$ & 0 & 0.0 & 1 & 100.0 & 0 & 0.0 & 0 & 0.0 & 1 & 0.6 \\
\hline$\$ 9,000-\$ 10,499$ & 1 & 20.0 & 2 & 40.0 & 1 & 20.0 & 1 & 20.0 & 5 & 2.9 \\
\hline$\$ 10,500-\$ 11,999$ & 1 & 25.0 & 3 & 75.0 & 0 & 0.0 & 0 & 0.0 & 4 & 2.4 \\
\hline$\$ 12,000-\$ 13,499$ & 1 & 50.0 & 1 & 50.0 & 0 & 0.0 & 0 & 0.0 & 2 & 1.2 \\
\hline$\$ 13,500-\$ 14,999$ & 0 & 0.0 & 1 & 100.0 & 0 & 0.0 & 0 & 0.0 & 1 & 0.6 \\
\hline$\$ 15,000-\$ 16,499$ & 1 & 100.0 & 0 & 0.0 & 0 & 0.0 & 0 & 0.0 & 1 & 0.6 \\
\hline$\$ 16,500-\$ 17,999$ & 1 & 50.0 & 1 & 50.0 & 0 & 0.0 & 0 & 0.0 & 2 & 1.2 \\
\hline$\$ 18,000-\$ 19,499$ & 1 & 33.3 & 1 & 33.3 & 1 & 33.3 & 0 & 0.0 & 3 & 1.8 \\
\hline$\$ 19,500-\$ 20,999$ & 0 & 0.0 & 1 & 50.0 & 1 & 50.0 & 0 & 0.0 & 2 & 1.2 \\
\hline$\$ 21,000-\$ 22,499$ & 0 & 0.0 & 0 & 0.0 & 1 & 100.0 & 0 & 0.0 & 1 & 0.6 \\
\hline$\$ 24,000-\$ 25,499$ & 1 & 100.0 & 0 & 0.0 & 0 & 0.0 & 0 & 0.0 & 1 & 0.6 \\
\hline$\$ 25,000-\$ 26,999$ & 0 & 0.0 & 0 & 0.0 & 1 & 100.0 & 0 & 0.0 & 1 & 0.6 \\
\hline$\$ 27,000-\$ 28,499$ & 0 & 0.0 & 0 & 0.0 & 1 & 100.0 & 0 & 0.0 & 1 & 0.6 \\
\hline$\$ 28,500-\$ 29,999$ & 0 & 0.0 & 2 & 100.0 & 0 & 0.0 & 0 & 0.0 & 2 & 1.2 \\
\hline$\$ 30,000$ or more & 7 & 43.8 & 4 & 25.0 & 3 & 18.8 & 2 & 12.5 & 16 & 9.4 \\
\hline Total & 49 & 28.8 & 85 & 50.0 & 22 & 12.9 & 14 & 8.2 & 170 & 100 \\
\hline
\end{tabular}


When asked to report the degree to which their sales from farmers' markets contributed to their total household income, more than half of the vendors $(n=103,56.3 \%)$ said that their market sales accounted for $10 \%$ or less of their total household income. This category served as both the mode and median range. Nearly $18 \%(n=32)$ claimed that their market sales represented $11-20 \%$ of their total household income. Six vendors (3.3\%) claimed that market sales accounted for $91-100 \%$ of their total household income (see table 27 ).

Table 27

Farmers' Market Sales as a Percent of Total Business and Total Household Income

\begin{tabular}{lcccc}
\hline & \multicolumn{2}{l}{ Total Business Income } & \multicolumn{2}{c}{ Total Household Income } \\
\hline Categories & $N$ & $\%$ & 103 & 56.3 \\
$10 \%$ or less & 46 & 25.1 & 32 & 17.5 \\
$11-20 \%$ & 20 & 10.9 & 8 & 4.4 \\
$21-30 \%$ & 10 & 5.5 & 4 & 2.2 \\
$31-40 \%$ & 9 & 4.9 & 12 & 6.6 \\
$41-50 \%$ & 21 & 11.5 & 2 & 1.1 \\
$51-60 \%$ & 6 & 3.3 & 3 & 1.6 \\
$61-70 \%$ & 7 & 3.8 & 2 & 1.1 \\
$71-80 \%$ & 13 & 7.1 & 3 & 1.6 \\
$81-90 \%$ & 14 & 7.7 & 6 & 3.3 \\
$91-100 \%$ & 26 & 14.2 & 8 & 4.4 \\
Missing value & 11 & 6.0 & 183 & 100.0 \\
\hline Total & 183 & 100.0 & & \\
\hline
\end{tabular}


In order to look at the income data in relation to hours worked, vendors were asked to indicate how many labor hours per week were devoted to the agricultural enterprise for which they used farmers' markets as an outlet during the production season. The question was divided into two categories, yielding information on a) how many hours worked by the respondent including unpaid family members, and b) hours worked by paid family members or other hired labor. For the first question, the most frequently reported category was 50 or more hours $(n=$ 53, 29\%), while the median category was 30-39 hours (see Table 28). Few respondents reported having paid labor. Three-quarters of the respondents $(n=138,75.4 \%)$ reported using no hired labor whatsoever during the production season. Both the 20 hours or less category and the 50 hours or more category contained $7.7 \%$ of the respondents $(n=14)$.

Table 28

Summary of Number of Hours Worked for Production and Marketing of Products

\begin{tabular}{|c|c|c|c|c|}
\hline \multirow[b]{2}{*}{ Categories } & \multicolumn{2}{|c|}{$\begin{array}{l}\text { Owner \& Unpaid } \\
\text { Family Members }\end{array}$} & \multicolumn{2}{|c|}{$\begin{array}{l}\text { Hired Labor \& } \\
\text { Paid Family }\end{array}$} \\
\hline & $N$ & $\%$ & $N$ & $\%$ \\
\hline No hours & 5 & 2.7 & 138 & 75.4 \\
\hline Less than 20 hours & 47 & 25.6 & 14 & 7.7 \\
\hline 20-29 hours & 33 & 18.0 & 4 & 2.2 \\
\hline 30-39 hours & 17 & 9.3 & 7 & 3.8 \\
\hline 40-49 hours & 22 & 12.0 & 2 & 1.1 \\
\hline $50+$ hours & 53 & 29.0 & 14 & 7.7 \\
\hline Missing value & 6 & 3.3 & 4 & 2.2 \\
\hline Total & 183 & 100.0 & 183 & 100.0 \\
\hline
\end{tabular}


In addition, vendors were also asked to disclose the number of hours per week they had some kind of employment other than their agricultural enterprise. Well over half $(n=109$, $59.6 \%)$ had no other employment, while $16.4 \%(n=30)$ were engaged in other employment for 40 hours or more each week (see Table 29).

Table 29

Hours of Other Employment

\begin{tabular}{lcc}
\hline \multicolumn{1}{c}{ Categories } & $\boldsymbol{N}$ & $\%$ \\
\hline None & 109 & 59.6 \\
$1-9$ hours & 3 & 1.6 \\
$10-19$ hours & 10 & 5.5 \\
$20-29$ hours & 13 & 7.1 \\
$30-39$ hours & 16 & 8.7 \\
$40-49$ hours & 26 & 14.2 \\
50 or more hours & 4 & 2.2 \\
Missing value & 2 & 1.1 \\
\hline Total & 183 & 100.0 \\
\hline
\end{tabular}

In an effort to understand the degree to which vendors were benefiting from the redemption of WIC or Senior Farmers' Market Nutrition Program (FMNP) vouchers, the instrument asked respondents to indicate the percentage of total farmers' market sales which were derived from such vouchers in 2004. Over half of the vendors $(n=96,52.5 \%$, $)$ claimed that vouchers accounted for $20 \%$ or less of their total market sales from that season, and 24 of the vendors (13.1\%) specifically indicated that they did not or could not accept FMNP vouchers (see Table 30). More than one-quarter of the respondents $(n=46)$ indicated that vouchers 
accounted for between $21 \%$ and $61 \%$ of their total market sales in 2004 (see Table 30). A small percentage $(n=3,1.6 \%)$ attributed $81-100 \%$ of their sales to either WIC or Senior FMNP vouchers.

The majority of those indicating that vouchers accounted for none of their total sales also indicated that they were not certified to accept such vouchers. This was due to the fact that the items they sold (eggs, baked goods, meats, flowers, etc.) were not considered 'fresh produce,' and consequently not covered by either program.

Table 30

Farmers' Market Nutrition Program Vouchers as a Percent of Total Farmers' Market Sales in 2004

\begin{tabular}{lcc}
\hline Categories & $N$ & $\%$ \\
\hline None & 24 & 13.1 \\
$20 \%$ or less & 96 & 52.5 \\
$21-40 \%$ & 23 & 12.6 \\
$41-60 \%$ & 23 & 12.6 \\
$61-80 \%$ & 11 & 6.0 \\
$81-100 \%$ & 3 & 1.6 \\
Missing value & 3 & 1.6 \\
\hline Total & 183 & 100.0 \\
\hline
\end{tabular}

\section{Educational Needs}

The survey instrument contained a series of Likert-scale questions designed to ascertain the perceived usefulness of certain educational topics. For each topic, vendors were asked to rank each topic as 1 (Completely unhelpful), 2 (Not very helpful), 3 (Somewhat helpful), or 4 
(Very helpful). The topic most frequently rated as 'very helpful' was educating consumers about local foods $(M=3.58)$. Other topics considered the most useful to their operation included display, signage, and packaging techniques $(M=3.34)$, new crops $(M=3.18)$, and season extension $(M=2.97)$. Topics mostly considered 'not very helpful' include tax management $(N=$ $44)$ and transitioning to organic production $(n=41)$. Vendors were least interested in bookkeeping skills, tax management, web site development, and transitioning to organic production (see Table 31). Educational resources on to transitioning to organic production were the most likely to be considered 'completely unhelpful' $(n=36,26.5 \%)$.

Vendors were also invited to specify other topics that they would consider beneficial to their continued operation as a direct-marketing agricultural entrepreneur. These topics, as well as those identified as obstacles to success, were coded from the open-ended portions of the surveys and analyzed by frequency. Only those mentioned by three or more vendors are reported in the tables.

Other educational topics were identified by 51 (27.8\%) of the respondents. The percentages are based on a total of fifty-one. The most common among the educational topics identified was consumer education $(n=7,13.7 \%)$ (see Table 32). Specifically, these vendors suggested that consumers need to learn about the benefits of supporting local producers, as well as how to cook and preserve produce. According to responding vendors, "information for consumers on why taking the time to purchase local produce is a benefit to them," would be highly useful. 
Table 31

Helpfulness of Educational Topics

\begin{tabular}{|c|c|c|c|c|c|c|c|c|c|}
\hline \multirow[b]{2}{*}{ Categories } & \multicolumn{2}{|c|}{$\begin{array}{l}\text { Completely } \\
\text { unhelpful }\end{array}$} & \multicolumn{2}{|c|}{$\begin{array}{l}\text { Not very } \\
\text { helpful }\end{array}$} & \multicolumn{2}{|c|}{$\begin{array}{l}\text { Somewhat } \\
\text { helpful }\end{array}$} & \multicolumn{2}{|c|}{ Very helpful } & \multirow[b]{2}{*}{$M$} \\
\hline & $N$ & $\%$ & $N$ & $\%$ & $N$ & $\%$ & $N$ & $\%$ & \\
\hline $\begin{array}{l}\text { Educating Consumers About } \\
\text { Local Foods }\end{array}$ & 5 & 3.4 & 6 & 4.0 & 36 & 24.2 & 102 & 68.5 & 3.58 \\
\hline $\begin{array}{l}\text { Display, Signage \& } \\
\text { Packaging Techniques }\end{array}$ & 6 & 4.0 & 16 & 10.7 & 49 & 32.7 & 79 & 52.7 & 3.34 \\
\hline New Crops & 12 & 8.5 & 20 & 14.1 & 41 & 28.9 & 69 & 48.6 & 3.18 \\
\hline Season Extension & 17 & 12.1 & 27 & 19.3 & 39 & 27.9 & 57 & 40.7 & 2.97 \\
\hline Grant Funds for On-Farm Research & 22 & 15.4 & 28 & 19.6 & 34 & 23.8 & 59 & 41.3 & 2.91 \\
\hline $\begin{array}{l}\text { Health Regulations for } \\
\text { Processed Products }\end{array}$ & 20 & 14.2 & 27 & 19.1 & 43 & 30.5 & 51 & 36.2 & 2.89 \\
\hline Bookkeeping Skills & 23 & 16.5 & 35 & 25.2 & 51 & 36.7 & 30 & 21.6 & 2.63 \\
\hline Tax Management & 23 & 16.5 & 44 & 31.7 & 43 & 30.9 & 29 & 20.9 & 2.56 \\
\hline Web Site Development & 36 & 26.1 & 27 & 19.6 & 40 & 29.0 & 35 & 25.4 & 2.54 \\
\hline Transitioning to Organic & 36 & 26.5 & 41 & 30.1 & 34 & 25.0 & 25 & 18.4 & 2.35 \\
\hline
\end{tabular}


Also ranked as being helpful was pest control, with six vendors requesting more information on controlling insect, weed, and deer damage. Additional common themes (each mentioned by five respondents) include a need to develop ways to learn and share experiences and ideas with other markets (via newsletters, conferences, hotlines, and other means of communicating), and learning about business management (including licensing, insurance, health and labeling requirements) (see Table 32). One vendor requested a "newsletter from the Extension Service on what is happening at other West Virginia markets, sources for reasonably priced packaging and labels, and the laws and regulations on labeling, especially nutritional content."

Table 32

Other Educational Topics Identified by Vendors

\begin{tabular}{lcc}
\hline Categories & N & \% \\
\hline Educating Customers & 7 & 13.7 \\
Pest Control (Including Deer) & 6 & 9.8 \\
Way of Learning About Other Markets and Sharing Ideas & 5 & 9.8 \\
Business Management \& License Requirements & 5 & 7.8 \\
New Varieties & 4 & 7.8 \\
Better Outreach About Available Programs & 4 & 7.8 \\
Market Management Training & 4 & 7.8 \\
How to Advertise the Market & 4 & 5.9 \\
How to Build or Gain Access to Processing Facilities & 3 & 5.9 \\
Regulations to Keep Non-Local Produce from Being Sold by Resellers & 3 & 5.9 \\
WIC \& Senior FMNP & 3 & \\
\hline
\end{tabular}


Other topics (each mentioned by four respondents) were new varieties of produce, better government outreach of available programs outside of "a chosen few" producers, market management training, and how to advertise more effectively (see Appendix E). Three vendors felt that there should be regulations specifically designed to prevent re-sellers or "pin-hookers" from marketing produce purchased from a wholesaler. An equal number of vendors $(n=3$, $5.9 \%$ ) felt that there needed to be more outreach and education concerning both the WIC and Senior Farmers' Market Nutrition Programs, and that vouchers should apply to a wider range of products, including eggs and other animal products.

\section{Obstacles to Success}

In order to assess the perceived roadblocks to success at farmers' markets, vendors were asked to comment on the largest obstacles to their success as a vendor. Percentages were based on a total of 102 respondents who identified obstacles. Many vendors $(n=20,19.6 \%)$ indicated an obstacle with vendors who sold products they did not produce themselves, many of them charging lower prices making it difficult to compete (see Table 33). Respondents thought this posed a major threat to local farmers, particularly when the re-sellers were accepting farmers' market nutrition vouchers issued by the state. One vendor suggested that a sting operation be conducted in order to "bust those liars and cheats!" (see Appendix F). This is consistent with the feeling reported by many vendors that specific regulations should prevent such re-sellers from participating in markets. The second most frequently mentioned obstacle $(n=16,15.7 \%)$ suggested that a lack of sufficient advertising and promotion of farmers' markets was a hindrance to their overall growth and success.

Many of the cited obstacles revolved around issues of market management, as several respondents ( $n=12,11.8 \%$ ) noted management as being absent, inadequate, or unfair (see Table 
33). Poor leadership was cited by several vendors as the cause of problems such as re-selling, competition, low prices, and little consensus on how to advertise and gain more community support. As one respondent advised, 'to be successful, a farmers' market must have a set time of operation, rules and regulations that are enforced, a good manager, and be a 'growers only' market." Several respondents noted that farmers' markets are losing their older customer base, which knows how to prepare and preserve fresh produce and frequently buys in bulk. This population was being replaced by younger people who "don't know how to cook" or simply don't understand the benefits of supporting local growers. As one respondent described, "Younger people do not cook more than 2-3 meals per week compared to the older generations that cooked every day. Volume sales have been in decline in the past few years. More needs to be done by farmers' markets to draw middle-aged customers with families to buy produce."

Other market-related issues mentioned by the vendors include a need for more customers ( $n=8,7.8 \%)$, a need for more vendors $(n=6,5.9 \%)$, poor location $(n=6,5.9 \%)$, limited market hours $(n=3,2.9 \%)$, and a need for more markets $(n=3,2.9 \%)$ (see Table 33). Some of the respondents $(n=3,2.9 \%)$ cited other vendors as obstacles, particularly stubborn "older generations of farmers unwilling to adapt to new rules, marketing techniques, and crops.”

Certain personal issues related to the respondents themselves include lack of time $(n=8$, $7.8 \%)$, age $(n=6,5.9 \%)$, poor health $(n=5,4.9 \%)$. Those vendors indicating that time was among the largest obstacles for them cited difficulty in having other employment and still managing to complete farm chores and care for their families. Production related obstacles included preventing pest and deer damage $(n=5,4.9 \%)$ as well as a lack of profit generated from farmers' markets $(n=5,4.9 \%)$. Similarly, small economy of scale was cited by three $(2.9 \%)$ of the vendors. 
Table 33

Obstacles to Future Success of Farmers’ Markets

\begin{tabular}{|c|c|c|}
\hline Categories & $N$ & $\%$ \\
\hline Resellers & 20 & 19.6 \\
\hline Lack of Advertising and Promotion & 16 & 15.7 \\
\hline Unfair or Inadequate Market Management & 12 & 11.8 \\
\hline Lack of Time & 8 & 7.8 \\
\hline Need for More Customers & 8 & 7.8 \\
\hline Unhelpful Government Agencies & 7 & 6.9 \\
\hline Age & 6 & 5.9 \\
\hline Burdensome Regulations & 6 & 5.9 \\
\hline Poor Location & 6 & 5.9 \\
\hline Need for More Vendors & 6 & 5.9 \\
\hline Customers not Knowing How to Cook & 6 & 5.9 \\
\hline Poor Health & 5 & 4.9 \\
\hline No Profit & 5 & 4.9 \\
\hline Poor Promotion of FMNP Vouchers & 5 & 4.9 \\
\hline Pests (Including Deer) & 5 & 4.9 \\
\hline Loss of Older Customers; No Young Customers & 4 & 3.9 \\
\hline Limited Market hours & 3 & 2.9 \\
\hline Older, Stubborn Farmers & 3 & 2.9 \\
\hline Small Economy of Scale & 3 & 2.9 \\
\hline Need for More Markets & 3 & 2.9 \\
\hline
\end{tabular}


Among the most frequently cited obstacles were various institutions or rules which the vendors found either frustrating or confusing. A common theme of resentment for government agencies which do not provide support or do not understand their own regulations was noted $(n=7,6.9 \%)$, particularly relating to health regulations for processed products and samples. Some felt that health regulations were inconsistent in that they varied from "county to county and state to state," and were "applied indiscriminately and with confusion even by the inspectors themselves." In fact, six of the vendors (5.9\%) specifically indicated that burdensome regulations presented an obstacle to the future success of farmers' markets.

In addition, several vendors $(n=5,4.9 \%)$ vocalized a lack of outreach and promotion regarding the WIC and Senior Farmers' Market Nutrition Program vouchers. Other obstacles mentioned include a lack of certified processing facilities, a lack of overall product diversity at farmers' markets, rising costs of production, and the "corporate food system," which fosters a "lack of understanding about food systems on the part of the consumer" (see Appendix F). 


\author{
CHAPTER V \\ Summary, Conclusions and Recommendations
}

\title{
Purpose of the Study
}

The purpose of this study was to identify the characteristics of farmers' market vendors in West Virginia. In addition, this study sought to identify the obstacles and educational needs relevant to farmers' market vendors and serve as a tool for the development of educational programming for both producers and consumers. The Extension Service and other community developers can therefore serve a greater role in the further development of farmers' markets as an integral part of sustainable local food systems in West Virginia.

\section{Objectives of the Study}

The objectives of this study were to identify general characteristics, products, promotional strategies, sales levels, season extension methods, and other characteristics of producers who use farmers' markets as a retailing outlet. In addition, this study aimed to identify educational needs and obstacles as perceived by farmers' market vendors in West Virginia. The objectives also sought to identify specific program objectives for Extension in the educational support of direct-marketing producers in West Virginia.

\section{Research Questions}

The following research questions were used to guide the development of this study:

1. What were the demographics of farmers selling at West Virginia farmers' markets?

2. What products were produced by farmers' market vendors in 2004 ?

3. How many months of the year were farmers able to market products via farmers' markets? 
4. What season extension methods were used by growers who sell at West Virginia farmers' markets?

5. What promotional and marketing methods were used by vendors at West Virginia farmers' markets?

6. How did vendors believe their prices compared with prices received for products of similar quality at supermarkets?

7. What were the gross sales earned by vendors at farmers' markets?

8. What percentage of the sales derived by vendors at West Virginia farmers' markets was attributable to Women, Infant \& Children (WIC) or Senior Farmers' Market Nutrition Program (FMNP) vouchers?

9. What percent of the vendors' total household income was derived from sales at farmers' markets?

10. What directions for improvement did vendors perceive as necessary for overall market success?

11. What educational needs did farmers' market vendors identify as potentially helpful?

12. What obstacles did farmers' market vendors perceived as the greatest threats to the future success of farmers' markets in West Virginia?

\section{Summary}

General characteristics of farmers' market vendors. In keeping with census data trends which report the average West Virginia farmer as 56.3 years of age, the majority of respondents in this study were over 50 years of age $(n=113,61.7 \%)$ (USDA, 2004b). The median age range was 50 to 59 years $(n=45,24.6 \%)$, with $37.2 \%(n=68)$ of the vendors 60 years of age or older. Slightly over three-fourths $(82 \%)$ of the respondents were residents of West Virginia. 
Slightly over half of the vendors responding to the survey were males $(n=103,57.9 \%)$, in contrast to the $73.4 \%$ of male farm operators in West Virginia as a whole (USDA, 2004b). Both males and females were evenly distributed among the highest level of education received, although a higher percentage of females (27.6\%) had some education beyond college than males (17.5\%). Respondents indicating that they were an equal partner in a business with someone else were treated separately in a 'partner' category $(n=23,12.6 \%)$, regardless of whether their partner was a spouse, sibling, child, or friend.

In addition to sales at farmers' markets, $16.4 \%(n=30)$ and $14.2 \%(n=26)$ of the vendors sold at on-farm stands or roadside stands respectively. More than $10 \%$ sold wholesale to stores or markets $(n=23,12.6 \%)$ and directly to restaurants $(n=21,11.5 \%)$. One of the vendors $(.5 \%)$ used mail order as a marketing technique and none used the internet as a sales outlet.

In terms of the number of markets in which vendors participated in 2004, responses ranged from one to ten, with an average of 1.61 . The average vendor spent 2.42 days selling at a farmers' market per week in the peak of the season, similar to Payne's findings of 2.1 as the average number of days farmers' markets in the Mid-Atlantic are open for business (Payne, 2002). Though there were ten vendors (5.5\%) who traveled 50 miles or more one way to attend their main farmers' market, slightly less than two-thirds of the vendors $(n=111,60.6 \%)$ traveled less than 20 miles. The average category of 10-19 miles one-way is less than the Mid-Atlantic average of 38 miles and the New Jersey average of 27 miles (Payne, 2002; Govindasamy, et al., 1998).

Products of farmers' market vendors. While vegetables represented the bulk of products produced by farmers' market vendors, there were a diverse array of other products sold in 2004 as well. The maximum product diversity was among vegetables in August, September, October, 
and November $(\operatorname{Max}=20)$. For fruits, maximum diversity was achieved in July with 80 different products, while the highest number of fruits products by a given vendor was five, in September. Dairy \& egg products were produced the most in June, July, and August $(M=.148)$, and eggs were produced by twelve vendors in each month of the year. Cut flower \& herb production peaked in August $(M=.513)$, while live plant production peaked in June $(M=.574)$. Meats, the least frequently produced of all categories, peaked in mean production in October $(M=.077)$. However, the months reaching a maximum diversity per vendor were December and January $(M a x=3)$. Processed or 'value-added' products peaked in production in September $(M=.399)$, with a maximum per vendor diversity of six products.

Overall, production of products other than vegetables was comparatively low, especially animal products like meat and dairy. While few vendors tended to produce these products, they were more prevalent in months either before or after the peak vegetable season, indicating that they were used as a way to extend the product offering or to meet another marketing demand once the farmers' market season had ended. This is somewhat to be expected, given that fewer than half (44\%) of producer-only farmers' markets in Maryland, Southeastern Pennsylvania, and Washington, D.C. offered meats for sale at any point in the season (Oberholtzer \& Grow, 2003). In the entire Mid-Atlantic region, only $49 \%$ of markets allowed meat and poultry for sale, and $32 \%$ of markets allowed the sale of dairy products (Payne, 2002).

Organic products were produced by at least one vendor in each product category. Relative to the periods in which many farmers' markets tend to operate in West Virginia (July, August, September), there were many fewer items produced in 'off' months (i.e. early spring, winter, and late fall months). 
When asked about their planned product offerings for the next farmers' market season, only $9.8 \%$ said they planned to offer fewer (or no) products than in 2004. Nearly half (42.1\%) said they hoped to offer more products for sale in 2005 at West Virginia farmers' markets. The same percentage also believed that the overall product diversity at the farmers' markets needed to increase.

Season extension. While slightly less than one-third $(n=59)$ of the vendors used farmers' markets as outlets for two months or less in 2004, slightly more than one-fifth ( $n=40)$ sold at a minimum of one farmers' market for more than five months in 2004. On average, vendors were selling at farmers' markets for 9-12 weeks, compared to the 20 weeks that the average farmers' market in the Mid-Atlantic operated in 2000 (Payne, 2002). This corresponds to the fact that more than one-half of the respondents claim to use no season extension methods whatsoever. Exactly one-third of vendors $(n=61)$ wanted their main farmers'market to begin earlier in the season, and more than one-fifth $(n=38,20.8 \%)$ wanted it to end later in the season.

Promotional strategies used at farmers' markets. The most popular method of promotion among West Virginia's farmers' market vendors consisted of offering free samples or tastings ( $n=71)$, followed by offering bulk discounts $(n=62)$. Terms used frequently in the labeling of products at market were 'home grown' ( $n=116,63.4 \%)$, 'fresh' $(n=98,53.6 \%)$, 'family farm' ( $n=67,36.6 \%)$, and 'natural' $(n=36,19.7 \%)$. Nearly twenty percent $(n=36)$ used either some form of 'organic' or 'pesticide-free'. To communicate with customers, many vendors $(n=63$, $34.4 \%)$ used business cards. Other popular forms of advertising were recipes $(n=39,21.3 \%)$, photographs $(n=27,14.8 \%)$, and face-to-face conversations $(n=22,12 \%)$.

The majority of vendors did not have liability insurance to cover sales at farmers' markets. However, nearly ten percent $(n=18)$ were covered by an umbrella group policy of the 
market organization. The rest paid for a policy themselves or simply did not know if they were covered. Sixty percent $(n=110,60.1 \%)$ believed that advertising of the market should increase, and $42 \%(n=77)$ believed overall product diversity at the market should increase. Fifty-six of the vendors (30.6\%) thought that an increase in the enforcement of market rules was necessary, corresponding with the desire some vendors expressed for preventing non-producing re-sellers at farmers' markets.

Pricing methods used by farmers' market vendors. Nearly $65 \%(n=100)$ of the respondents said their prices were lower than those charged for products of similar quality at grocery stores. In addition, one quarter of the respondents intentionally set their prices below grocery store prices. The most frequently used method of establishing prices for products, however, was comparison with other vendors at the market $(n=105,57.4 \%)$, though a third of the vendors $(n=61)$ developed their prices by calculating cost of production plus profit margin.

Sales levels and income of farmers' market vendors. While the most frequently reported sales category on a per day basis was $\$ 199$ or less, over 30\% $(n=57)$ earned somewhere between $\$ 200$ and $\$ 599$ on a given market day in the peak of the season. Fewer than $10 \%(n=$ 14) reported sales of $\$ 1,000$ or more. For the entire 2004 season, the median total sales range was $\$ 1,500-\$ 2,999$. This stands in contrast to the Agricultural Census' report that of the 1,434 West Virginia farms who sold directly to consumers in $2002,50.8 \%$ sold less than $\$ 1,000$ worth of directly marketed products (USDA, 2004c). More than a third of vendors in Payne's national study had annual market sales under $\$ 1,000$, but among vendors in the Mid-Atlantic region, average market sales in the 2000 season exceeded \$32,000 (Payne, 2002).

In the $\$ 1,500-\$ 2,999$ sales category, $60 \%(n=12)$ reported that they were 'somewhat satisfied' with the profit margin at farmers' markets, which is in keeping with the median 
category of profit margin satisfaction. Though more than half of the vendors $(n=103,56.3 \%)$ claimed that farmers' market sales accounted for $10 \%$ or less of their total household income, they accounted, on average, for $41-50 \%$ of sales of their total agricultural enterprise. Nearly $13 \%$ of the respondents $(n=22)$ sold more than $\$ 21,000$ in products at farmers' markets in the same time period. This may indicate that markets could be making large economic impacts on rural households.

While in general farmers' market sales accounted for a relatively small percentage of total household income for most of the vendors, over $40 \%(n=75,41 \%)$ indicated that they and other unpaid family members devoted 40 or more hours per week on the production and marketing of products sold at farmers' markets. Fifty of the vendors $(27.3 \%)$ devoted somewhere between 20 and 40 hours per week. Nearly $60 \%$ had no other employment, and very few vendors hired labor or paid family members to work on their enterprise.

In $2000,65 \%$ of markets in the Mid-Atlantic region participated in WIC FMNP program (Payne, 2002). More than two-thirds of the respondents in this study said that FMNP vouchers accounted for $20 \%$ or less of their total sales, though $7.6 \%(n=14)$ received more than $60 \%$ of their total sales in the form of vouchers.

Educational needs as perceived by farmers' market vendors. Interestingly, the educational category most frequently considered 'very helpful' was educating consumers about local foods, which was in keeping with many vendors perceptions that more advertising, education and outreach needs to be done to make people more aware of benefits of shopping at farmers' markets. Other topics considered helpful were display, signage, and packaging techniques, new crops, and season extension. When vendors were asked to identify topics they thought would be helpful, several suggested pest control $(n=6)$, communication forums for 
farmers' market issues $(n=5)$, and both business and market management $(n=5)$.

Obstacles to the future success of farmers' markets in West Virginia. More than twenty distinct issues were brought up when vendors were asked to comment on what they perceived as the greatest obstacles to farmers' market success in West Virginia. Most common among these were the presence of certain vendors who sell products they did not in fact produce themselves. Though $67 \%$ of farmers' markets in the Mid-Atlantic classified themselves as 'producer-only' in 2000, over half permitted items for resale (Payne, 2002). The next most frequent category was unfair or inadequate market management, including lax regulations which fail to prohibit resellers. Also cited was the need for more advertising, more customers, and more vendors, as well as more cooperation from government agencies like the West Virginia Department of Agriculture, West Virginia University Extension, and state and local health departments.

\section{Conclusions}

Based on the findings of this study, the following conclusions were reached:

- It is possible that partnerships went under-reported, given that there was no specific 'partner' category offered for that question. The degree to which farmers' market vendors are operating as a shared, family business is not known.

- Products which vendors use to extend the season into the colder months include garlic, salad greens, all types of live plants, eggs, beef, herbs, and processed products such as baked goods, condiments, jams/preserves, and soaps. Overall, less than half of the respondents used any season extension technique to prolong production of warmer season crops.

- The fact that many vendors wanted their farmers' market to begin earlier and/or end later in the season indicates a degree of interest in making the farmers' market season more 
closely match the potential production season.

- Well over half of West Virginia's farmers' market vendors who responded to the survey have no other employment other than their agricultural enterprise. While there is a high degree of variability among the hours vendors are devoting to their agricultural enterprises, most either work less than 20 hours per week or more than 50 hours per week. Nevertheless, more than half of the vendors claimed that market sales represented $10 \%$ or less of their total household income in 2004 . Few of the vendors used hired labor in their operations. It is unclear whether this is because these vendors are engaged in their agricultural enterprise on a part-time or retired basis.

- For most respondents, Farmers' Market Nutrition Program Vouchers accounted for 20\% or less of the total market sales in 2004. However, more than one-quarter reported that these vouchers accounted for $21-60 \%$ of their total market sales, indicating that they are in fact playing a significant role for some vendors.

- Farmers' market sales account for varying degrees of vendors' total agricultural operation income. This indicates that vendors are using other entrepreneurial outlets in addition to farmers' markets in order to sell their products.

- Most vendors sold less than \$3,000 at West Virginia’s farmers' markets in 2004, much less than their counterparts in the rest of the Mid-Atlantic. However, some of the vendors in this study sold more than $\$ 21,000$ in products, which could represent a significant impact on rural households. On average, farmers' market sales represented nearly half of the income generated by vendors' agricultural enterprises.

- Farmers' market vendors in West Virginia perceive a lack of sufficient advertising as one of their biggest obstacles. This, in addition to a need for more consumer education and a 
need for consistent regulations prohibiting sales from non-producers was identified as a direction of change desired by many vendors.

- Vendors indicated that the Extension Service, the West Virginia Department of Agriculture, and other state agencies need to do more to provide educational resources to farmers' market vendors, as well as devote resources to outreach programs which educate consumers about the importance of buying locally.

\section{Recommendations}

Based on the review of literature, the researcher's experience, and the results of this study, the following recommendations are made to West Virginia University Extension Service, West Virginia Department of Agriculture, West Virginia Department of Health and Human Resources, farmers' market managers, and other state and local agencies and organizations interested in the sustained viability of farmers' markets in West Virginia:

- $\quad$ Resources should be devoted to season extension workshops and field days which encourage use of high tunnels, row covers, and other means of season extension, including new varieties.

- $\quad$ Educational resources need to be devoted to pest management, including affordable means of preventing deer damage.

- $\quad$ Educational resources should be devoted to the topic of liability insurance.

- A feasibility study should be conducted to assess potential establishment of an umbrella liability insurance policy for the coverage of farmers' markets around the state.

- Educational resources should be devoted to conducting cooking demonstrations and giving away recipes at farmers' markets throughout the state.

- $\quad$ Resources should be devoted to making concerted, collaborative efforts to educate the 
public about why supporting local farms is important, and how farmers' markets can provide a fun, nutritious means of doing so. This may involve the coordination and implementation of 'buy local' campaigns that can be conducted at the state or county level.

- Market management training should be conducted in order to foster leadership, consistent enforcement of rules (including producer-only clauses), adequate promotion and advertising, knowledge of health regulations concerning sale and sampling of products, licensing requirements, and recruiting new vendors.

- Market managers should collaborate with community organizations to sponsor events in concert with market hours of operation in order to foster more community support of farmers' markets.

- $\quad$ Resources should be devoted to the development of a forum for communication of farmers' market issues, including potential newsletters, email list-serves, conferences, or websites.

- $\quad$ Regulatory agencies overseeing rules concerning sales of animal products, processed products and providing samples should work to ensure consistent interpretation and enforcement at the state and county level. Agricultural entrepreneurship would be encouraged by making clear and concise regulatory documentation available to producers who want to extend their season with value-added products.

- $\quad$ Resources from relevant state (and possibly federal) agencies should be devoted to conducting improved outreach campaigns to Farmers' Market Nutrition Program voucher recipients about the purchase and preparation of fresh local produce.

- Agricultural and Economic Development educators should work with their respective 
Departments of Health in order to understand and promote better understanding of regulations around sales of animal products and value-added products, as well as the availability of certified processing facilities.

\section{Additional Research}

- Economic impact analysis should be conducted based on the sales levels of farmers' market vendors in West Virginia, possibly broken down by region.

- Studies should be conducted which identify consumer perceptions of the barriers to patronizing farmers' markets, products they prefer to purchase at farmers' markets, and what kinds of community activities they would prefer in concert with local farmers' markets.

- Studies should be conducted which identify characteristics of farmers' market managers in West Virginia, including the types of legal organization, management techniques, employment status (volunteer or paid), and means of market promotion.

- Studies should be conducted which determine the types of consumer advertising that work most effectively in the communication of messages to buy locally-produced food.

- Comparative studies should be conducted to determine the characteristics of West Virginia producers utilizing other direct-marketing outlets such as Community Supported Agriculture and Pick-Your-Own operations.

- Studies should be conducted to determine educational needs of new farmers in relation to educational needs of veteran farmers. 


\section{REFERENCES}

Abel, J., Thomson, J., \& Maretzki, A. (1999, October). Extension's role with farmers' markets: Working with farmers, consumers, \& communities. Journal of Extension 37(5). Retrieved September 14, 2004 from http://www/joe.org/joe/199october/a4.html

Ary, D., Jacobs, L. C., \& Razavieh, A. (2002). Introduction to research in education (6 ${ }^{\text {th }}$ ed.). Belmont, CA: Wadsworth/Thompson Learning.

Brown, A. (2001). Counting Farmers' Markets. The Geographical Review 91(4):655-674.

Retrieved on March 28, 2005 from http://nutrition.tufts.edu/pdf/publications/afe/browncounting-gr.pdf.

Census Bureau. (2003). Metropolitan statistical areas and components, 2003, with codes.

Retrieved on December 13, 2004 from http://www.census.gov/population/estimates/metro-city/03msa.txt.

Census Bureau (2000). Jefferson county quickfacts. Retrieved on October 7, 2004 from http:/quickfacts.census.gov/qfd/states/54/54037.html.

Chesapeake Fields Institute (2004, April). Local and organic: Bringing Maryland organics from farm to table. Chestertown, Maryland: no author.

Clemens, R. (2004). The expanding U.S. market for fresh produce. Ames, Iowa: Iowa State University, Center for Agricultural and Rural Development.

Corum, V., Rosenzweig, M., \& Gibson, E. (2001). The new farmers’ market. Auburn, California: New World Publishers.

Dillman, D. A. (2000). Mail and internet surveys: The tailored design method (2 ${ }^{\text {nd }}$ ed.). New York: John Wiley \& Sons, Inc. 
Feenstra, G. W. (1997). Local food systems \& sustainable communities. American Journal of Alternative Agriculture, 12(1), 28-36.

Gale, F. (1997). Direct farm marketing as a rural development tool. Rural Development Perspectives, 12(2): 19-25. USDA/ERS. Retrieved on September 29, 2004, from http://www.ers.usda.gov/publications/rdp/rdp0297/rdp0297d.pdf.

Govindasamy, R., Hossain, F. \& Adelaja, A. (1999). Income of farmers who use direct marketing. Agricultural and Resource Economics Review, 28(1): 76-83.

Govindasamy, R., Italia, J., \& Adelaja, A. (2002). Farmers' markets: Consumer trends, preferences, and characteristics. Journal of Extension, 40(1). Retrieved July 11, 2004 from http://www.joe.org/joe/2002february/rb6.html.

Govindasamy, R., Zurbriggen, M., Italia, J., Adelaja, A., Nitzsche, P., \& VanVranken, R. (1998a). Farmers' markets: Managers characteristics and factors affecting market organization. New Jersey Agricultural Experiment Station. Retrieved August 13, 2004 from http://aesop.rutgers.edu/ agecon/pub/fm_mn.pdf.

Govindasamy, R., Zurbriggen, M., Italia, J., Adelaja, A., Nitzsche, P., \& VanVranken, R. (1998b). Farmers’ markets: Producers' characteristics and status of their businesses. Rutgers Cooperative Extension. Retrieved September 16, 2004 from http://aesop.rutgers.edu/ agecon/pub/fm pr.pdf.

Hamilton, N. D. (2002). Farmers' markets rules, regulations and opportunities. The National Center for Agricultural Law. Retrieved on November 20, 2004 from http://www.NationalAgLawCenter.org. 
Henneberry S. \& Agustini, H. (2002, November). Creating a successful farmers' market: Highlights of farmers' market consumers' and producers' survey results. Paper presented at the 2002 Future Farms Conference. Retrieved September 10, 2004, from http://www.kerrcenter.com/publications/2002 proceedings/successful farmmarket.pdf. Survey Instrument Retrieved on September 10, 2004 from http://www.kerrcenter.com/farmers_market/producer_survey.pdf.

Jack, R. L. \& Blackburn, K. L. (1984). Effect of place of residence on consumer attitudes concerning fresh produce marketed through direct farm markets in West Virginia. (Bulletin 685). West Virginia Agricultural \& Forestry Experiment Station.

Kohls, R. L. \& Uhl, J. N. (1998). Marketing of agricultural products ( $8^{\text {th }}$ ed.). Upper Saddle River, New Jersey: Prentice Hall, Inc.

Lewis, J. L. (2002). How farmers in West Virginia are using value-added processing to increase annual income (Masters thesis, West Virginia University, 2002). Retrieved on October 5, 2004 from http://kitkat.wvu.edu:8080/files/2385.1.Lewis Jennifer thesis.pdf.

Lyson, T. A., Gillespie Jr., G. W., \& Hilchey, D. (1995). Farmers' markets and the local community: Bridging the formal and informal economy. American Journal of Alternative Agriculture 10(3), 108-113.

Lyson, T. A. (2000). Moving toward civic agriculture. Choices 15(3), 42-45.

McConnell, T. R. \& Czemerda, K. (2002). West Virginia specialty crops vegetable production summary. Unpublished manuscript, West Virginia University Extension Service.

National Commission on Small Farms. (1998). A time to act: A report of the USDA National Commission on Small Farms. MP-1545. Retrieved on December 20, 2004 from http://www.csrees.usda.gov/nea/ag_systems/pdfs/time to_act_1998.pdf. 
Oberholtzer, L. \& Grow, S. (2003). Producer-only farmers' markets in the Mid-Atlantic region: A survey of market managers. Arlington, VA: Henry A. Wallace Center for Agricultural \& Environmental Policy at Winrock International.

Patten, M. L. (2002). Understanding research methods ( ${ }^{\text {rd }}$. ed.). Los Angeles, California: Pyrczak Publishing.

Payne, T. (2002). U.S. farmers' markets—2000: A study of emerging trends. United States Department of Agriculture. Retrieved on October 15, 2004 from http://www.ams.usda.gov/tmd/MSB/PDFpublist/FarmMark.pdf.

Pirog, R. (2003). Checking the food odometer: Comparing food miles for local versus conventional produce sales to Iowa institutions. Ames, Iowa: Iowa State University, Leopold Center for Sustainable Agriculture. Retrieved on October 27, 2004 from http:/www.leopold.iastate.edu/pubs/staff/files/food_travel072103.pdf.

Planck, N. (2004a). Markets and beyond: Expanding the market for local foods, part one. The Rodale Institute. Retrieved on October 27, 2004 from http://www.newfarm.org/features/1004/ pmarket/index.shtml.

Planck, N. (2004b). A few words on selling at farmers' markets: Part one. North American Direct Marketing Association Market Connection 9(1), 5-7.

Planck, N. (2004c). A few words on selling at farmers' markets: Part two. North American Direct Marketing Association Market Connection 9(2), 4-6.

Robinson, J. P., Shaver, P. R., \& Wrightsman, L. S. (1991). Criteria for scale selection and evaluation. In J. P. Robinson, P. R. Shaver, \& L. S. Wrightsman (Eds.) Measures of personality and social psychological attitudes (pp.1-16) New York: Academic Press. 
Steele, C. J. (1997). Why U.S. agriculture and rural areas have a stake in small farms. Rural Development Perspectives, 12(2), 26-31. Retrieved on October 15, 2004, from http://www.ers.usda.gov/publications/rdp/rdp0297/rdp0297e.pdf.

United States Department of Agriculture, Agricultural Marketing Service. (2002). Farmers market growth. Retrieved September 26, 2004 from http://www.ams.usda.gov/farmersmarkets/FarmersMarketGrowth.htm.

United States Department of Agriculture. (2004a). 2002 census of agriculture. Historical highlights: 2002 and earlier census years. Retrieved September 30, 2004 from http://www.nass.usda.gov/census/census02/volume1/wv/st54_1_001_001.pdf.

United States Department of Agriculture. (2004b). 2002 census of agriculture. Retrieved September 16, 2004 from http://www.nass.usda.gov/census/census02/volume1/wv/st54_2_004_028.pdf.

United States Department of Agriculture. (2004c). 2002 Census of agriculture. Market value of agricultural products sold including direct and organic: 2002 and 1997. Retrieved September 10, 2004 from http://www.nass.usda.gov/census/census02/volume1/wv/st54_2_002_002.pdf.

United States Department of Agriculture. (2004d). 2002 Census of agriculture. Summary by age and primary occupation of principal operator. Retrieved September 29, 2004 from http://www.nass.usda.gov/census/census02/volume1/wv/st54_1_060_060.pdf.

United States Department of Agriculture. (2004e, April). USDA awards \$16.7 million in grants to 41 states and six Indian tribal organizations for the senior farmers' market nutrition programs. (Release No. 0156.04). Retrieved September 29, 2004 from http://www.fns.usda.gov/cga/PressRelease/2004/PR-0156.htm. 
United States Department of Agriculture. (2004f). Women, infants and children program data. Retrieved on September 29, 2004, from http://www.fns.usda.gov/pd/wichome.htm. United States Department of Agriculture. (2004g). Farms and land in farms (Revised March 3, 2004) Retrieved on October 26, 2004 from http://usda.mannlib.cornell.edu/reports/nassr/other/zfl-bb/fmno0204.pdf.

United States Department of Agriculture. (2000). Direct marketing today: challenges and opportunities. Retrieved on October 15, 2004 from http://www.ams.usda.gov/tmd/MSB/PDFpublist/directmarketingtoday.pdf.

United States Department of Agriculture. (1999). 1997 Census of Agriculture. Market value of agricultural products sold and direct sales: 1997, 1992, and 1987. Retrieved September 30, 2004 from http://www.nass.usda.gov/census/census97/volume1/wv-48/wv1_02.pdf.

West Virginia Department of Health and Human Resources (WVDHHR). (2002). Obesity: Facts, figures \& guidelines. Retrieved on October 14, 2004 from http://www.wvdhhr.org/bph/oehp/obesity/execsum.htm.

West Virginia University Extension Service (2004). West Virginia farmers' market directory. Retrieved October 13, 2004 from http://www.wvu.edu/ agexten/farmman2/farmmrkts.htm.

Wolf, M. M. (1997). A target consumer profile \& positioning for promotion of the direct marketing of fresh produce: A case study. Journal of Food Distribution Research, 12-17. Young, C. E. \& Kantor, L. S. (1999). Moving toward the food guide pyramid: Implications for U.S. agriculture. Agricultural Economic Report No. 779. Retrieved on October 16, 2004 from http://www.ers.usda.gov/publications/aer799/aer779fm.pdf. 


\section{APPENDICES}


APPENDIX A:

Survey Instrument 


\title{
FARMERS' MARKET VENDOR SURVEY
}

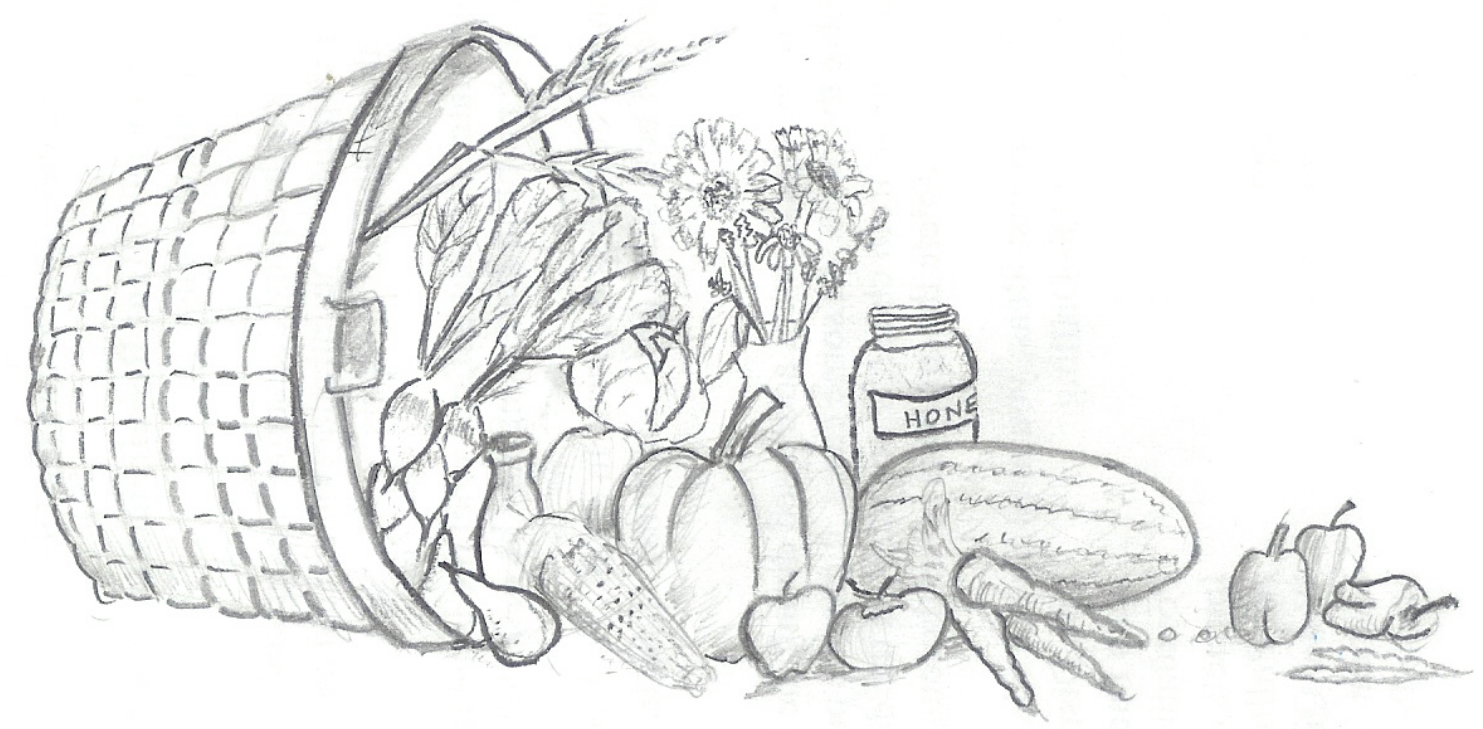

\author{
Stacy M. Miller \\ Graduate Student \\ Agricultural \& Environmental Education \\ West Virginia University \\ P.O. Box 6108 \\ Morgantown, WV 26506
}


Cover illustration by Dr. Mark Sperow and Stacy M. Miller, 2005 
Thank you for taking the time to complete this important questionnaire, which contains 50 questions. For questions with several answer choices, please mark your answer with an ' $X$ ' inside the corresponding $\square$. If you did not sell at farmers' markets in 2004, please answer number 1 only and return your survey in the envelope provided.

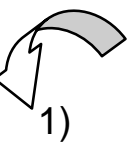

START HERE

Where did you sell your farm products in 2004 ?

(Please ' $X$ ' all that apply)

$\begin{array}{ll}\square 1 & \text { Farmers' markets } \\ \square 2 & \text { Restaurants } \\ \square 3 & \text { Wholesale to grocery stores/supermarkets } \\ \square 4 & \text { Pick-your-own } \\ \square 5 & \text { Flea markets } \\ \square 6 & \text { On-farm stand } \\ \square 7 & \text { Roadside stand } \\ \square 8 & \text { Subscription service or Community Supported Agriculture } \\ \square 9 & \text { Internet orders } \\ \square 10 & \text { Catalogue mail-order } \\ \square 11 & \text { Did not sell any farm products in } 2004 \\ \square 12 & \text { Other: }\end{array}$

2) How many different farmers' markets (with 2 or more vendors) did you participate in as a vendor during the 2004 growing season?

(Number of farmers' markets attended in 2004)

3) During the peak of the season in 2004, how many days of the week did you or someone from your operation sell at a farmers' market?

(Number of days per week products were sold at a farmers' market)

4) Did you sell any at farmers' markets outside of West Virginia in 2004?

$\begin{array}{ll}\square 0 & \text { No } \\ \square 1 & \text { Yes (please indicate which state(s): }\end{array}$ 
5) During an average week in the 2004 season, how many hours did you, family members, or hired labor devote to the production and marketing of products for which you use farmers' markets as an outlet?

You/unpaid family members

$\square 1$ Less than 20 hours

- 20-29 hours

प3 30-39 hours

$\square 4$ 40-49 hours

$\square 550$ or more hours
Hired Labor/ paid family

members

$\square 1$ Less than 20 hours

- 20-29 hours

口3 30-39 hours

$\square 4$ 40-49 hours

$\square 550$ or more hours

6) How many weeks did you market your products at one or more farmers' market in 2004?

$\begin{array}{ll}\square 1 & 1-4 \text { weeks } \\ \square 2 & 5-8 \text { weeks } \\ \square 3 & 9-12 \text { weeks } \\ \square 4 & 13-16 \text { weeks } \\ \square 5 & 17-20 \text { weeks } \\ \square 6 & 21 \text { or more weeks }\end{array}$

7) What distance did you travel (one way) to attend your main farmers' market in 2004?

$\begin{array}{ll}\square 1 & 0-9 \text { miles } \\ \square 2 & 10-19 \text { miles } \\ \square 3 & 20-29 \text { miles } \\ \square 4 & 30-39 \text { miles } \\ \square 5 & 40-49 \text { miles } \\ \square 6 & 50 \text { miles or more }\end{array}$

8) Do you have product liability insurance for your participation in farmers' market(s)?

$\begin{array}{ll}\square 0 & \text { No } \\ \square 1 & \text { Yes } \\ \square 2 & \text { I don't know } \\ \square 3 & \text { No, but I am covered by a policy held by the market }\end{array}$


9) What promotional strategies do you use when selling at farmers' markets? (please ' $X$ ' all that apply)

$\square 1$ Buy a certain number, get one free

$\square 2$

Bulk discounts

Bargaining

Free samples/tastings

Seconds or canning quality at a reduced rate

$\square 6$ Combinations of products into a 'package'

$\square 7$ Other:

10) What terms do you use to label your products at the farmers' market according to production practices? (please ' $X$ ' all that apply)

$\begin{array}{ll}\square 1 & \text { Family farm } \\ \square 2 & \text { Natural } \\ \square 3 & \text { Fresh } \\ \square 4 & \text { Home grown } \\ \square 5 & \text { Hand made or Hand crafted } \\ \square 6 & \text { Certified organic } \\ \square 7 & \text { Chemical-free } \\ \square 8 & \text { Heirloom } \\ \square 9 & \text { Free-range } \\ \square 10 & \text { Grass-fed } \\ \square 11 & \text { Other: }\end{array}$

11) What methods do you use to give information to your customers about your operation or ways in which they can use your products? (please ' $X$ ' all that apply)

$\begin{array}{ll}\square 1 & \text { Newsletter mailing list } \\ \square 2 & \text { Photos of your farm or facility } \\ \square 3 & \text { Brochures } \\ \square 4 & \text { Business cards } \\ \square 5 & \text { Email lists } \\ \square 6 & \text { Recipe cards } \\ \square 7 & \text { Website } \\ \square 8 & \text { Other: }\end{array}$


12) Please use the spreadsheet on pages 4-5 to indicate (with an ' $X$ ') the months in which your operation sold the following products at a farmers' market in 2004. For any products that are sold as organic, please mark with an 'OG' instead of an ' $X$ '. List any additional 'other' products on page 12.

\begin{tabular}{|c|c|c|c|c|c|c|c|c|c|c|c|c|}
\hline Vegetables & JAN & FEB & MAR & $A P R$ & MAY & JUN & $J U L$ & $A \cup G$ & SEP & $O C T$ & NOV & $D E C$ \\
\hline Asparagus & & & & & & & & 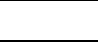 & & & & \\
\hline \multicolumn{13}{|l|}{$\begin{array}{l}\text { Beans } \\
\text { (Green) }\end{array}$} \\
\hline \multicolumn{13}{|l|}{$\begin{array}{l}\text { Beans } \\
\text { (Shell) }\end{array}$} \\
\hline \multicolumn{13}{|l|}{ Beets } \\
\hline \multicolumn{13}{|l|}{ Broccoli } \\
\hline \multicolumn{13}{|l|}{$\begin{array}{l}\text { Brussels } \\
\text { Sprouts }\end{array}$} \\
\hline Cabbage & & & & & & & & 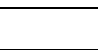 & & & & 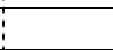 \\
\hline Carrots & & & & & & & & 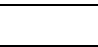 & & & & 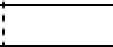 \\
\hline \multicolumn{13}{|l|}{ Cauliflower } \\
\hline \multicolumn{13}{|l|}{ Celery } \\
\hline \multicolumn{13}{|l|}{ Corn } \\
\hline Eggplant & & & & & & & & 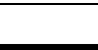 & 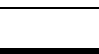 & & & 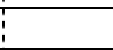 \\
\hline \multicolumn{13}{|l|}{$\begin{array}{l}\text { Cooking } \\
\text { greens }\end{array}$} \\
\hline \multicolumn{13}{|l|}{ Cucumbers } \\
\hline \multicolumn{13}{|l|}{ Garlic } \\
\hline \multicolumn{13}{|l|}{ Lima Beans } \\
\hline Mushrooms & & & & & & & & & & & & \\
\hline \multicolumn{13}{|c|}{ Okra } \\
\hline \multicolumn{13}{|l|}{ Onions } \\
\hline \multicolumn{13}{|l|}{ Parsnips } \\
\hline \multicolumn{13}{|l|}{ Peppers } \\
\hline \multicolumn{13}{|l|}{ Rhubarb } \\
\hline \multicolumn{13}{|l|}{ Potatoes } \\
\hline \multicolumn{13}{|l|}{ Radishes } \\
\hline \multicolumn{13}{|l|}{ Ramps } \\
\hline \multirow{2}{*}{\multicolumn{13}{|c|}{$\begin{array}{l}\text { Salad } \\
\text { Greens }\end{array}$}} \\
\hline & & & & & & & & & & & & \\
\hline \multirow{2}{*}{\multicolumn{13}{|c|}{$\begin{array}{l}\text { Squash- } \\
\text { Summer }\end{array}$}} \\
\hline & & & & & & & & & & & & \\
\hline \multirow{2}{*}{\multicolumn{13}{|c|}{$\begin{array}{l}\text { Squash- } \\
\text { Winter }\end{array}$}} \\
\hline & & & & & & & & & & & & \\
\hline \multirow{2}{*}{\multicolumn{13}{|c|}{$\begin{array}{l}\text { Sweet } \\
\text { Potatoes }\end{array}$}} \\
\hline & & & & & & & & & & & & \\
\hline Tomatoes & & & & & & & & & & & & \\
\hline Turnips & & & & & & & & & & & & \\
\hline Other: & & & & & & & & & & & & \\
\hline & & & & & & & & & & & & \\
\hline
\end{tabular}




\begin{tabular}{|c|c|c|c|c|c|c|c|c|c|c|c|c|}
\hline Dairy \& Eggs & JAN & $F E B$ & $M A R$ & $A P R$ & MAY & JUN & $J U L$ & $A \cup G$ & SEP & $O C T$ & NOV & $D E C$ \\
\hline Cheese & & ' & (n) & & & 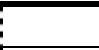 & & & & 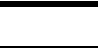 & 6 & \\
\hline Milk & & 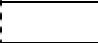 & . & & & : & & & & & 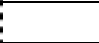 & \\
\hline Yogurt & & 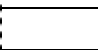 & 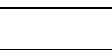 & & & 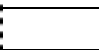 & & & & & 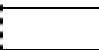 & \\
\hline Eggs & & 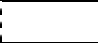 & & & & & & & & & & \\
\hline Other: & & 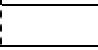 & & & & & & & & & 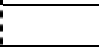 & \\
\hline Meat & JAN & FEB & $M A R$ & $A P R$ & MAY & JUN & JUL & $A \cup G$ & SEP & $O C T$ & NOV & $D E C$ \\
\hline Beef & & & & & & 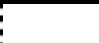 & & & & & ? & \\
\hline Poultry & & & & & & 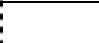 & & & & & & \\
\hline Pork & & & & & & 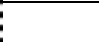 & & & & & 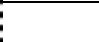 & \\
\hline Other: & & 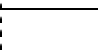 & & & & 1 & & & & & & \\
\hline
\end{tabular}

\begin{tabular}{|c|c|c|c|c|c|c|c|c|c|c|c|c|}
\hline Live Plants & JAN & $F E B$ & MAR & $A P R$ & MAY & JUN & $J U L$ & $A \cup G$ & SEP & $O C T$ & NOV & $D E C$ \\
\hline Annuals & & & & & & & & & & & & \\
\hline Perennials & & & & & & & & & & & & \\
\hline Bedding plants & & & & & & & & & & & & \\
\hline Other: & & & & & & & & & & & & \\
\hline
\end{tabular}

\begin{tabular}{|c|c|c|c|c|c|c|c|c|c|c|c|c|}
\hline Fruits \& nuts & JAN & $F E B$ & MAR & $A P R$ & MAY & JUN & $J U L$ & $A \cup G$ & SEP & $O C T$ & NOV & $D E C$ \\
\hline Chestnuts & & & & & & & & & & & & \\
\hline Bramble fruits & & & & & & & & & & & & \\
\hline Blueberries & & & & & & & & & & & & \\
\hline Melons & & & & & & & & & & & & \\
\hline Pawpaws & & & & & & & & & & & & \\
\hline Persimmons & & & & & & & & & & & & \\
\hline Strawberries & & & & & & & & & & & & \\
\hline Tree fruits & & & & & & & & & & & & \\
\hline Other: & & & & & & & & & & & & \\
\hline
\end{tabular}

Herbs \&

Flowers JAN FEB MAR APR MAY JUN JUL AUG SEP OCT NOV DEC

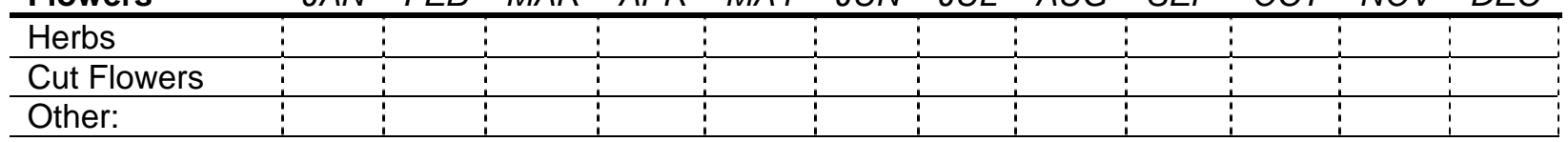

\begin{tabular}{|c|c|c|c|c|c|c|c|c|c|c|c|c|}
\hline $\begin{array}{l}\text { Processed } \\
\text { Products }\end{array}$ & JAN & $F E B$ & MAR & $A P R$ & MAY & JUN & JUL & $A \cup G$ & SEP & $O C T$ & NOV & $D E C$ \\
\hline Baked goods & & & 0 & & 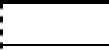 & 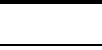 & & & & & & \\
\hline Cider & & & 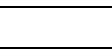 & & 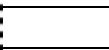 & 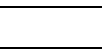 & & & & & & \\
\hline Condiments & & & 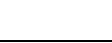 & & 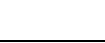 & 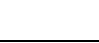 & & & & & & \\
\hline Honey & & & & & & & & & & & & \\
\hline Jams/Preserves & & & & & & & & & & & & \\
\hline Salad Dressing & & & & & & & & & & & & \\
\hline Soaps & & & & & & & & & & & & \\
\hline Wool & & & 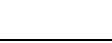 & & & & & & & & 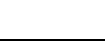 & \\
\hline Other: & & & 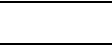 & & & & & & & & & \\
\hline & & & 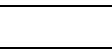 & & & 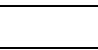 & & 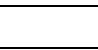 & & & & \\
\hline
\end{tabular}


13) What methods do you use in order to extend your production season?

(Please ' $X$ ' all that apply)

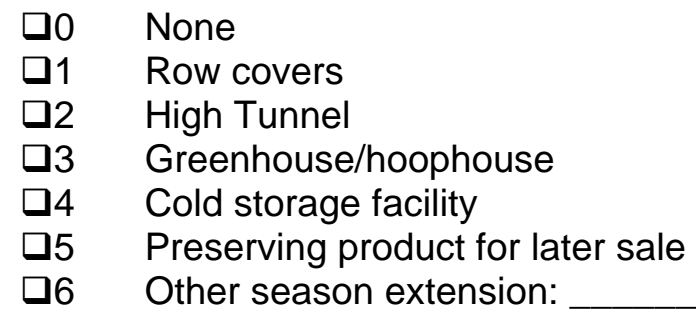

14) Suppose you could begin the market season at any point you were willing and able to provide enough products to sell to generate a profit. Would you begin the market season earlier, later, or at the same time?

$\begin{array}{lll}\text { a1 } & \text { Earlier:_ } & \text { (please indicate your ideal month) } \\ \text { व2 } & \text { Later: } & \text { (please indicate your ideal month) } \\ \text { व3 } & \text { The same time }\end{array}$

15) Suppose you could end the market season at any point you were no longer willing and able to provide enough products to sell to generate a profit. Would you end the market season earlier, later, or at the same time?

$\begin{array}{lll}\square 1 & \text { Earlier:_ } & \text { (please indicate your ideal month) } \\ \text { प2 } & \text { Later: } & \text { (please indicate your ideal month) } \\ \square 3 & \text { The same time } & \end{array}$

16) Do you plan to offer fewer, the same number, or more products for sale at farmers' markets in the coming season?

$\begin{array}{ll}\square 1 & \text { Fewer products } \\ \square 2 & \text { More products } \\ \square 3 & \text { The same number of products }\end{array}$


17-25) Please place an ' $X$ " next to each item to indicate what direction of change you wish to see at the primary farmers' market you attend. If you are satisfied with the current state of the item, select "no change".

17) Market hours of operation

18) Days of each week open for business

19) Length of market season

20) Membership dues

21) Advertising of the market

22) Number of produce vendors

23) Number of non-produce vendors

24) Overall diversity of products

25) Enforcement of market rules

26) On average, how do you think your prices compare with those of grocery stores for the same products of similar quality?

$\begin{array}{ll}\square 1 & \text { Significantly lower } \\ \square 2 & \text { Somewhat lower } \\ \square 3 & \text { About the same } \\ \square 4 & \text { Somewhat higher } \\ \square 5 & \text { Significantly higher } \\ \square 6 & \text { Don't know }\end{array}$

27) What methods do you use to establish prices for your products? (please ' $X$ ' all that apply)

$\square 1$ Above grocery store prices

$\square 2$ Below grocery store prices

$\square 3$ Same as grocery store prices

口4 Comparison with other farmers at market

$\square 5$ Your cost of production plus profit margin

06 Other: 
28) How satisfied are you with the profit margin generated from your farmers' market sales in 2004?

$\begin{array}{ll}\square 1 & \text { Very Satisfied } \\ \square 2 & \text { Somewhat Satisfied } \\ \square 3 & \text { Somewhat Unsatisfied } \\ \square 4 & \text { Very Unsatisfied }\end{array}$

29) On average, how many hours per week are you employed off-farm?

$\begin{array}{ll}\square 0 & \text { None } \\ \square 1 & 1-9 \text { hours } \\ \square 2 & 10-19 \text { hours } \\ \square 3 & 20-29 \text { hours } \\ \square 4 & 30-39 \text { hours } \\ \square 5 & 40-49 \text { hours } \\ \square 6 & 50 \text { or more hours }\end{array}$

30) What percent of your total sales at farmers' markets is accounted for by WIC and/or Senior Farmers' Market Nutrition Program Vouchers?

$\begin{array}{ll}\square 0 & \text { None } \\ \square 1 & 20 \% \text { or less } \\ \square 2 & 21 \%-40 \% \\ \square 3 & 41 \%-60 \% \\ \square 4 & 61 \%-80 \% \\ \square 5 & 81 \%-110 \%\end{array}$

31) What percent of your total farm income is from farmers' market sales?

$\begin{array}{ll}\square 1 & 10 \% \text { or less } \\ \square 2 & 11 \%-20 \% \\ \square 3 & 21 \%-30 \% \\ \square 4 & 31 \%-40 \% \\ \square 5 & 41 \%-50 \%\end{array}$

$\begin{array}{ll}\square 6 & 51 \%-60 \% \\ \square 7 & 61 \%-70 \% \\ \square 8 & 71 \%-80 \% \\ \square 9 & 81 \%-90 \% \\ \square 10 & 91 \%-100 \%\end{array}$


32) Which range best represents the average amount of sales on a single market day in the peak of the 2004 season?

$\begin{array}{ll}\square 1 & \$ 199 \text { or less } \\ \square 2 & \$ 200-\$ 399 \\ \square 3 & \$ 400-\$ 599 \\ \square 4 & \$ 600-\$ 799 \\ \square 5 & \$ 800-\$ 999 \\ \square 6 & \$ 1,000-\$ 1,199 \\ \square 7 & \$ 1,200-\$ 1,399 \\ \square 8 & \$ 1,400-\$ 1,599 \\ \square 9 & \$ 1,600-\$ 1,799 \\ \square 10 & \$ 1,800-\$ 1,999 \\ \square 11 & \$ 2,000 \text { or more }\end{array}$

33) What range represents your best estimate of your total sales (before deducting expenses) at farmers' markets in 2004?

$\begin{array}{ll}\square 1 & \$ 1,499 \text { or less } \\ \square 2 & \$ 1,500-\$ 2,999 \\ \square 3 & \$ 3,000-\$ 4,499 \\ \square 4 & \$ 4,500-\$ 5,999 \\ \square 5 & \$ 6,000-\$ 7,499 \\ \square 6 & \$ 7,500-\$ 8,999 \\ \square 7 & \$ 9,000-\$ 10,499 \\ \square 8 & \$ 10,500-\$ 11,999 \\ \square 9 & \$ 12,000-\$ 13,499 \\ \square 10 & \$ 13,500-\$ 14,999 \\ \square 11 & \$ 15,000-\$ 16,499 \\ \square 12 & \$ 16,500-\$ 17,999 \\ \square 13 & \$ 18,000-\$ 19,499 \\ \square 14 & \$ 19,500-\$ 20,999 \\ \square 15 & \$ 21,000-\$ 22,499 \\ \square 16 & \$ 22,500-\$ 23,999 \\ \square 17 & \$ 24,000-\$ 25,499 \\ \square 18 & \$ 25,500-\$ 26,999 \\ \square 19 & \$ 27,000-\$ 28,499 \\ \square 20 & \$ 28,500-\$ 29,999 \\ \square 21 & \$ 30,000 \text { or more }\end{array}$


34) What percent of your total household income is from farmers' market sales?

$\begin{array}{ll}\square 1 & 10 \% \text { or less } \\ \square 2 & 11 \%-20 \% \\ \square 3 & 21 \%-30 \% \\ \square 4 & 31 \%-40 \% \\ \square 5 & 41 \%-50 \%\end{array}$

$\begin{array}{lc}\square 6 & 51 \%-60 \% \\ \square 7 & 61 \%-70 \% \\ \square 8 & 71 \%-80 \% \\ \square 9 & 81 \%-90 \% \\ \square 10 & 91 \%-100 \%\end{array}$

35) What range best represents your total household income in 2004?

$\begin{array}{ll}\square 1 & \text { less than } \$ 5,000 \\ \square 2 & \$ 5,000-\$ 9,999 \\ \square 3 & \$ 10,000-\$ 14,999 \\ \square 4 & \$ 15,000-\$ 19,999 \\ \square 5 & \$ 20,000-\$ 24,999 \\ \square 6 & \$ 25,000-\$ 29,999 \\ \square 7 & \$ 30,000-\$ 34,999 \\ \square 8 & \$ 35,000-\$ 39,999 \\ \square 9 & \$ 40,000-\$ 44,999 \\ \square 10 & \$ 45,000-\$ 49,999 \\ \square 11 & \$ 50,000-\$ 54,999 \\ \square 12 & \$ 55,000-\$ 59,999 \\ \square 13 & \$ 60,000-\$ 64,999 \\ \square 14 & \$ 65,000-\$ 69,999 \\ \square 15 & \$ 70,000-\$ 74,999 \\ \square 16 & \$ 75,000-\$ 79,999 \\ \square 17 & \$ 80,000-\$ 84,999 \\ \square 18 & \$ 85,000-\$ 89,999 \\ \square 19 & \$ 90,000-\$ 94,999 \\ \square 20 & \$ 95,000-\$ 99,999 \\ \square 21 & \$ 100,000-\$ 104,999 \\ \square 22 & \$ 105,000-\$ 109,999 \\ \square 23 & \$ 110,000-\$ 114,999 \\ \square 24 & \$ 115,000-\$ 119,999 \\ \square 25 & \$ 120,000-\$ 124,999 \\ \square 26 & \$ 125,000 \text { or } \text { more }\end{array}$


36-45) How helpful would you find educational information on the following topics in order to support your enterprise and other direct-marketing agricultural producers? (Please circle a number 1-4, 4 being 'very helpful', 1 being 'not helpful'. Please provide comments that would help us better understand your response.)

36)

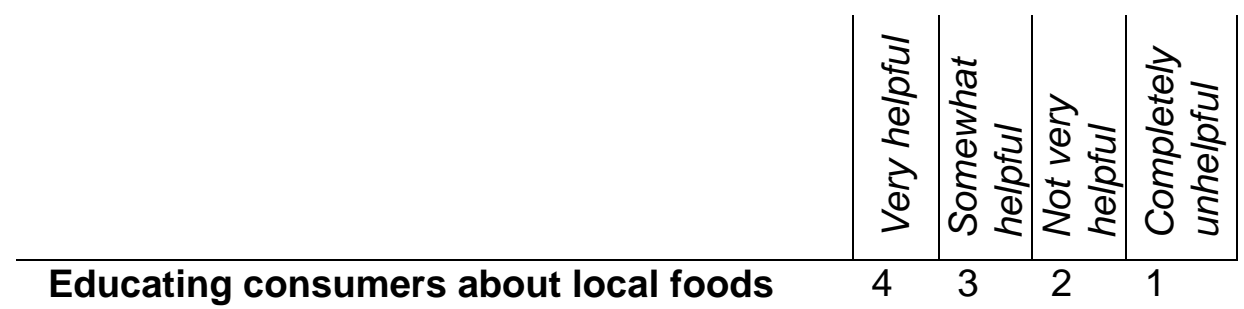

37) Display, signage \& packaging techniques $\quad$\begin{tabular}{lllll}
\hline & 3 & 2 & 1
\end{tabular}

38) Health regulations for processed products \begin{tabular}{lllll}
\hline 4 & 3 & 2 & 1
\end{tabular}

39) Grant-funds for on-farm research $\quad$\begin{tabular}{llll}
\hline & 3 & 2 & 1
\end{tabular}

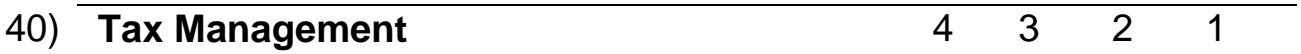

41) Bookkeeping skills $\quad$\begin{tabular}{lllll}
\hline & 3 & 2 & 1
\end{tabular}

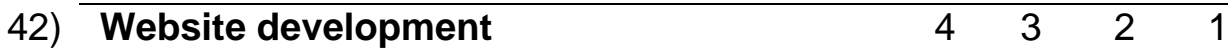

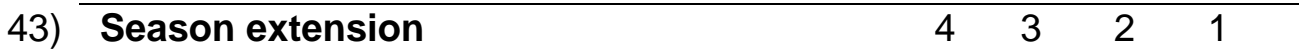

44) Transitioning to organic production $\quad$\begin{tabular}{llll}
\hline & 4 & 2 & 1
\end{tabular}

45) New crops 4 \begin{tabular}{llll}
\hline \\
\hline
\end{tabular} 
46) What other topics (not mentioned in question 36-45) would you consider beneficial to you as a producer?

Demographic Information:

47) Age:

$\square 1 \quad 18-20$ years

$\square 2 \quad 20-29$ years

口3 $30-39$ years

$\square 4 \quad 40-49$ years

$\square 5 \quad 50-59$ years

$\square 6$ 60-69 years

$\square 770$ years or more

48) Gender:
$\square 1$ Female
$\square 2$ Male

49) State of Residence:

$\begin{array}{lll}\square 1 & \text { West Virginia:_ County } \\ \square 2 & \text { Ohio: } & \text { County } \\ \square 3 & \text { Pennsylvania:— County } \\ \square 4 & \text { Maryland: } & \text { County } \\ \square 5 & \text { Other: } & \end{array}$

50) Highest Level of Education completed

a1 Grade School

口2 Some High School

प3 High School Diploma (including GED)

$\square 4$ Associate's Degree/Technical Degree

प5 Some College

$\square 6$ College Degree

77 Some Graduate School

प8 Master's Degree

$\square 9$ Doctoral Degree 
Please comment on any obstacles you perceive to your success as a farmers' market vendor in West Virginia.

Thank you for your time! 
In cooperation with:

Extension Service
West VurginiaUniversity. 
APPENDIX B:

First Mailing Cover Letter 
January 26, 2005

$<<$ First Name $>><$ Last Name $>>$
$<<$ Business Name $>>$
$<<$ Address $>>$
$<<$ City $>>,<<$ State $>><<$ Zip $>>$

Dear $<<$ First Name $>>$,

We hope the New Year finds you in good health and good company! You have been identified as a farmers' market vendor, and we are requesting your participation in this important research study on the role of farmers' markets in West Virginia.

The purpose of this research study is to identify the characteristics of farmers' market vendors as well as the opportunities and barriers to successful markets in West Virginia. The results will be used to partially fulfill the requirements for a Master of Science degree in Agricultural \& Environmental Education at West Virginia University. Answering the questions in this questionnaire, which should take you between 20 and 30 minutes, will greatly assist us in our efforts to understand the degree to which vendors rely on their market sales for income, as well as to identify the barriers and opportunities facing direct-marketing small farms.

In respect for your privacy, the information you provide in this questionnaire will remain as confidential as possible. Participation in this study is entirely voluntary and you are not required to answer every question. However, taking the time to respond honestly and thoughtfully to the enclosed questions will greatly help us to better serve small agricultural enterprises throughout the state, including farmers' markets.

The number written on the top of your booklet is a coding mechanism that allows us to track and follow-up with non-respondents. If you believe you have received this survey in error, we ask (with apologies) that you mail it back in the provided envelope so that we may remove your name from our mailing list. If you have further questions about the study, please address them to Stacy Miller at 304-293-6131 x4234.

Please return your completed questionnaire by February 11, 2005 in order to receive a free wall thermometer as a token of our appreciation. Thank you for your time and cooperation, and good luck in the coming year!

Sincerely,

Stacy M. Miller Graduate Student
Deborah A. Boone, Ph.D.

Assistant Professor Agricultural \& Environmental Education
Thomas R. McConnell Farm Management Specialist WVU Extension Service 
APPENDIX C:

Second Mailing Cover Letter 
February 24, 2005

$<<$ First Name $>><<$ Last Name $>>$
$<<$ Business Name $>>$
$<<$ Address $>>$
$<<$ City $>>,<<$ State $>><$ <ip $>>$

Dear $<<$ First Name $>>$,

Last month, you were sent an important questionnaire which asked you a series of questions about your experiences at West Virginia farmers' markets. You have been identified as a farmers' market vendor, and we are continuing to request your participation in this important research study. It is only with your help that we can better understand the role that farmers' markets play in the lives of agricultural and rural entrepreneurs across West Virginia. If you did not sell any products at a farmers' market in West Virginia in 2004, we apologize for any inconvenience. In that case, please answer Number 1 on the questionnaire and return in the envelope provided so that we may remove your name from our mailing list.

The purpose of this research study is to identify the characteristics of farmers' market vendors as well as the opportunities and barriers to successful markets in West Virginia. The results will be used to partially fulfill the requirements for a Master of Science degree in Agricultural \& Environmental Education at West Virginia University. Answering the questions in this questionnaire, which should take you between 20 and 30 minutes, will greatly assist us in our efforts to understand the degree to which vendors rely on their market sales for income, as well as to identify the barriers and opportunities facing direct-marketing small farms.

In respect for your privacy, the information you provide in this questionnaire will remain as confidential as possible. Participation in this study is entirely voluntary and you are not required to answer every question. However, taking the time to respond honestly and thoughtfully to the enclosed questions will greatly help us to better serve small agricultural enterprises throughout the state, including farmers' markets.

The number written on the top of your booklet is a coding mechanism that allows us to track and follow-up with non-respondents. If you have further questions about the study, please address them to Stacy Miller at 304-293-6131 x4234. Please return your completed questionnaire by March 11, 2005 in order to receive a free wall thermometer as a token of our appreciation. Thank you for your time and cooperation, and good luck in the coming year!

Sincerely,

Stacy M. Miller Graduate Student
Deborah A. Boone, Ph.D.

Assistant Professor Agricultural \& Environmental Education
Thomas R. McConnell Farm Management Specialist WVU Extension Service 
APPENDIX D:

Product Matrix Summary 


\begin{tabular}{|c|c|c|c|c|c|c|c|c|c|c|c|c|c|}
\hline Vegetables & $J A N$ & FEB & $M A R$ & $A P R$ & $M A Y$ & JUN & $J U L$ & $A U G$ & SEP & OCT & $\mathrm{NOV}$ & $D E C$ & total \\
\hline Asparagus & $\overline{0}$ & 0 & 1 & 8 & 12 & 7 & 2 & 1 & 1 & 0 & 0 & 0 & 32 \\
\hline Beans (Green) & 0 & 0 & 0 & 1 & 2 & $51 *$ & $112 * !$ & $111^{*}$ & $91 *$ & $38^{*}$ & 4* & 0 & 410 \\
\hline Beans (Shell) & 0 & 0 & 0 & 0 & 1 & $6^{*}$ & $15 *$ & $25^{*}$ & $21^{*}$ & $12 *$ & $1 *$ & 0 & 81 \\
\hline Beets & 0 & 0 & 0 & 3 & 7 & $35^{*}$ & $52 *$ & $50^{*}$ & $44 *$ & $27^{*}$ & $4 *$ & 0 & 222 \\
\hline Broccoli & $\overline{0}$ & $\overline{0}$ & 1 & 2 & $6^{*}$ & $24^{*}$ & $30^{*}$ & $19^{*}$ & $17^{*}$ & $14^{*}$ & $2 *$ & $\overline{0}$ & $\overline{115}$ \\
\hline $\begin{array}{l}\text { Brussels } \\
\text { Sprouts }\end{array}$ & 0 & 0 & 0 & 0 & 1 & 2 & $7 *$ & $8 *$ & $9 *$ & $7 *$ & $2 *$ & 0 & 36 \\
\hline Cabbage & 0 & 0 & 1 & 1 & 8 & $46^{*}:$ & $66^{*}$ & $63^{*}$ & $50^{*}$ & $29^{*}$ & $6^{*}$ & 0 & 270 \\
\hline Carrots & 0 & 0 & 0 & 2 & 2 & $6^{*}$ & $12 * !$ & $15 *:$ & $13 * !$ & $10^{*}$ & $2 *$ & 0 & 62 \\
\hline Cauliflower & 0 & 0 & 0 & 1 & $3 *$ & $7 *$ & $10 * !$ & $6^{*}$ & $6 *$ & 5 & $1 *$ & 0 & 39 \\
\hline Celery & 0 & 0 & 0 & 0 & 0 & 0 & 3 & 5 & 7 & 3 & 0 & 0 & 18 \\
\hline Corn & 0 & 0 & 0 & 0 & 1 & 13 & $58^{*}$ & $76^{*}$ & $60^{*}$ & $15^{*}$ & 0 & 0 & 223 \\
\hline Eggplant & 0 & 0 & 0 & 0 & 0 & 2 & $25 * !$ & $32 *:$ & $26 *:$ & $16^{*}$ & 1 & 0 & 102 \\
\hline $\begin{array}{l}\text { Cooking } \\
\text { greens }\end{array}$ & 0 & 0 & 1 & $4 *$ & $14^{*}$ & $28 * !$ & $32 * !$ & $31 *$ & $34 * !$ & $24^{*}$ & $5 *$ & 1 & $\overline{174}$ \\
\hline Cucumbers & 0 & 0 & 0 & 0 & 6 & $49 *$ & $105 * !$ & 104*: & $83 * !$ & $29^{*}$ & $1 *$ & 0 & 377 \\
\hline Garlic & $1^{*}$ & $1^{*}$ & $1^{*}$ & $1^{*}$ & $2^{*}$ & $14^{*}$ & $21 *$ & $18^{*}$ & $18^{*}:$ & $11^{*}$ & $3 *$ & $1 *$ & 92 \\
\hline Lima Beans & 0 & 0 & 0 & 0 & 0 & 2 & 6 & 15 & $16^{*}$ & $6^{*}$ & $1 *$ & 0 & 46 \\
\hline Mushrooms & 0 & 0 & 0 & 0 & 2 & 3* & $4 *$ & $4 *$ & $3^{*}$ & 0 & 0 & 0 & 16 \\
\hline Okra & 0 & 0 & 0 & 0 & 0 & 4 & 7 & 12 & 7 & 5 & 0 & 0 & 35 \\
\hline Onions & 0 & 0 & 3 & 5 & $19^{*}$ & $38 *:$ & $50 *:$ & $44^{*}$ & $39 *$ & $22 *$ & $5^{*}$ & 1 & 226 \\
\hline Parsnips & 0 & 0 & $1^{*}$ & 0 & 0 & 0 & 1 & 2 & $5 *$ & 5 & 1 & 1 & 16 \\
\hline Peppers & 0 & 0 & 0 & 0 & 2 & 20 & $87^{*}$ & $108^{*}$ & $94 *$ & $43^{*}$ & 1* & 0 & 355 \\
\hline Rhuba & 0 & 0 & 0 & $5^{*}$ & 9* & $24 *:$ & $26^{*}:$ & $22 *$ & $23 *$ & 9* & 1 & 0 & 119 \\
\hline Potato & 1 & 1 & 3 & 3 & 6 & $20 *$ & $58 *:$ & $70 *$ & $70^{*}:$ & $38^{*}$ & $8^{*}$ & 2 & 280 \\
\hline Radishes & 0 & 0 & 1 & 3* & $8 *$ & $14 *$ & $5^{*}$ & 3* & $5 *$ & $8^{*}$ & 3* & 0 & 50 \\
\hline Ramps & 0 & 0 & 0 & $1 *$ & 1 & 1 & 2 & 2 & 1 & 1 & 0 & 0 & 9 \\
\hline Salad Green & 1 & 1 & 3 & $7 *$ & $17 *$ & $29 *:$ & 29*: & $20^{*}$ & $21 *:$ & $15^{*}$ & $4 *$ & 2 & 149 \\
\hline $\begin{array}{l}\text { Squash- } \\
\text { Summer }\end{array}$ & 0 & 0 & 0 & 1 & 5 & $54 * !$ & $95^{*}:$ & $96^{*}$ & $79 * !$ & $30^{*}$ & $1 *$ & 0 & 361 \\
\hline $\begin{array}{l}\text { Squash- } \\
\text { Winter }\end{array}$ & 1 & 1 & 0 & 0 & 0 & 3 & $6^{*}$ & $21^{*}$ & $45^{*}$ & $41^{*}$ & $7 *$ & 1 & 126 \\
\hline $\begin{array}{l}\text { Sweet } \\
\text { Potatoes }\end{array}$ & 0 & 0 & 0 & 0 & 0 & $2 *$ & $2 *$ & $5 *$ & $19^{*}$ & $17^{*}$ & $1 *$ & 0 & 46 \\
\hline Tomatoes & 0 & 0 & 1 & 5 & 5 & 32 & $107 * i$ & $128 *:$ & $118^{*}:$ & $67 *$ & $4 *$ & 0 & 467 \\
\hline Turnips & 0 & 0 & 1 & 1 & 0 & $2 *$ & 6*: & 7* & $27 *$ & $33 *$ & $7 *$ & 1 & 85 \\
\hline Other: & 0 & 0 & 0 & 0 & 0 & 2* & 5*: & $6^{*}$ & 5* & 3 & 0 & 0 & 21 \\
\hline total & 4 & 4 & 18 & 54 & 139 & 540 & 1046 & 1129 & 057 & 583 & 76 & 10 & 1660 \\
\hline
\end{tabular}

Note: Asterisks $(*)$ indicate that one or more vendors represented in that category produced organic products. 
Dairy \&

\begin{tabular}{|c|c|c|c|c|c|c|c|c|c|c|c|c|c|c|}
\hline Eggs & & $J A N$ & FEB & $M A R$ & $A P R$ & $M A Y$ & JUN & JUL & $A U G$ & SEP & OCT & NOV & $D E C$ & total \\
\hline Cheese & 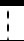 & 0 & 0 & 0 & 2 & 4 & 4 & 4 & 4 & 4 & 4 & 4 & 1 & 31 \\
\hline Milk & & 0 & 0 & 0 & 0 & 0 & 0 & 0 & 0 & 0 & 0 & 0 & 0 & $\mathbf{0}$ \\
\hline Yogurt & & 0 & 0 & 0 & 0 & 0 & 0 & 0 & 0 & 0 & 0 & 0 & 0 & $\mathbf{0}$ \\
\hline Eggs & & $12^{*}$ & $12^{*}$ & $12^{*}$ & $13^{*}$ & $17 *$ & $21^{*}$ & $21 *$ & $21^{*}$ & $20^{*}$ & $17 *$ & $15^{*}$ & $13^{*}$ & 194 \\
\hline Other: & 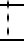 & 0 & 0 & 0 & 0 & 2 & 2 & 2 & 2 & 1 & 0 & 0 & 0 & 9 \\
\hline total & & 12 & 12 & 12 & 15 & 23 & 27 & 27 & 27 & 25 & 21 & 19 & 14 & 234 \\
\hline Meat & & JAN & FEB & $M A R$ & $A P R$ & $M A Y$ & JUN & $J U L$ & $A U G$ & SEP & OCT & NOV & $D E C$ & \\
\hline Beef & 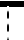 & 4 & 3 & 4 & 5 & 5 & 4 & 4 & 4 & 4 & 6 & 5 & 5 & 53 \\
\hline Poultry & 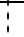 & 0 & 0 & 0 & 0 & 0 & 2* & 2* & 1 & $2 *$ & $2 *$ & 0 & 0 & 9 \\
\hline Pork & ! & 1 & 1 & 0 & 1 & 1 & 1 & 1 & 2 & 2 & 3 & 2 & 2 & 17 \\
\hline Other: & 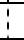 & 2 & 2 & 1 & 1 & 1 & 0 & 0 & 0 & 1 & 3 & 2 & 2 & 15 \\
\hline total & & 7 & 6 & 5 & 7 & 7 & 7 & 7 & 7 & 9 & 14 & 9 & 9 & 94 \\
\hline Live Plants & & JAN & $F E B$ & $M A R$ & $A P R$ & $M A Y$ & JUN & JUL & $A U G$ & SEP & OCT & $\mathrm{NOV}$ & $D E C$ & \\
\hline Annuals & & 2 & 2 & 4 & $21 *$ & $33^{*}$ & $32 *$ & $20 *$ & $10^{*}$ & 9* & 5 & 2 & 2 & 142 \\
\hline Perennials & $\vdots$ & 3 & 3 & 6 & $18^{*}$ & $29 *$ & $31 *$ & $26^{*}$ & $21^{*}$ & $19 *$ & $12 *$ & 4 & 3 & 172 \\
\hline Bedding & & & & 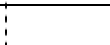 & & & & 7 & & & & 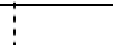 & 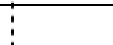 & 120 \\
\hline plants & 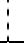 & 1 & 1 & 5 & 22 & 30 & 31 & 14 & 6 & 6 & 4 & 0 & 0 & \\
\hline Other: & $\vdots$ & 3 & 3 & 4 & 9 & $10 *$ & $11^{*}$ & 8 & 8 & 8 & 6 & 4 & 4 & 78 \\
\hline total & & 9 & 9 & 19 & 70 & 102 & 105 & 68 & 45 & 42 & 27 & 10 & 9 & 515 \\
\hline $\begin{array}{l}\text { Fruits \& } \\
\text { nuts }\end{array}$ & & $J A N$ & $F E B$ & $M A R$ & $A P R$ & $M A Y$ & JUN & $J U L$ & $A U G$ & SEP & OCT & NOV & $D E C$ & \\
\hline Chestnuts & & 0 & 0 & 0 & 0 & 0 & 0 & 0 & 2 & 2 & 3 & 1 & 1 & 9 \\
\hline $\begin{array}{l}\text { Bramble } \\
\text { fruits }\end{array}$ & 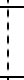 & 0 & 0 & 0 & 0 & 0 & 7 & $19 *$ & $16^{*}$ & 8 & 4 & 1 & 0 & 55 \\
\hline Blueberries & & 0 & 0 & 0 & 0 & 0 & $4 *$ & 13 & 9 & 4 & 1 & 0 & 0 & 31 \\
\hline Melons & 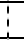 & 0 & 0 & 0 & 0 & 0 & 1 & 13 & 17 & 15 & 2 & 1 & 1 & 50 \\
\hline Pawpaws & 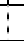 & 0 & 0 & 0 & 0 & 0 & 0 & 0 & 0 & $6 *$ & $4 *$ & 0 & 0 & 10 \\
\hline Persimmons & 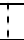 & 0 & 0 & 0 & 0 & 0 & 0 & 0 & 0 & 0 & 0 & 0 & 0 & $\mathbf{0}$ \\
\hline Strawberries & 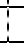 & 0 & 0 & 0 & 0 & 0 & 11 & 18 & 4 & 2 & 1 & 0 & 0 & 36 \\
\hline Tree fruits & 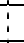 & 0 & 0 & 0 & 0 & 0 & 5 & 14 & $19 *$ & $20 *$ & 17 & 1 & 1 & 77 \\
\hline Other: & : & 0 & 0 & 0 & 0 & 0 & 1 & 3 & 6 & : $6^{*}$ & 2 & 1 & 1 & 20 \\
\hline total & & $\mathbf{0}$ & $\mathbf{0}$ & $\mathbf{0}$ & $\mathbf{0}$ & $\mathbf{0}$ & 29 & 80 & 73 & 63 & 34 & 5 & 4 & 288 \\
\hline $\begin{array}{l}\text { Herbs \& } \\
\text { Flowers } \\
\end{array}$ & & JAN & FEB & MAR & $A P R$ & MAY & JUN & JUL & $A U G$ & SEP & OCT & NOV & $D E C$ & \\
\hline Herbs & & 3 & 3 & 3 & $8^{*}$ & $24^{*}$ & $28^{*}$ & $29^{*}$ & $27^{*}$ & $24^{*}$ & $18^{*}$ & 3 & 2 & 172 \\
\hline Cut Flowers & 1 & 0 & 0 & 0 & 3 & $5^{*}$ & $12 *$ & $15^{*}$ & $17^{*}$ & $14 *$ & 9* & 2* & 0 & 21 \\
\hline Other: & : & 0 & 0 & 0 & 0 & 3 & 3 & 2 & 1 & 1 & 0 & 0 & 0 & 10 \\
\hline total & & 3 & 3 & 3 & 11 & 32 & 43 & 46 & 45 & 39 & 27 & 5 & 2 & 259 \\
\hline \begin{tabular}{|l|} 
Processed \\
Products \\
\end{tabular} & & JAN & FEB & $M A R$ & $A P R$ & MAY & JUN & JUL & $A U G$ & SEP & OCT & NOV & $D E C$ & \\
\hline Baked goods & & 3 & 3 & 3 & 9 & $13^{*}$ & $18^{*}$ & $24^{*}$ & $24 *$ & $25^{*}$ & $20 *$ & $10^{*}$ & 7 & 159 \\
\hline Cider & & 0 & 0 & 0 & 0 & 0 & 0 & 0 & 0 & 1 & 4 & 3 & 2 & 10 \\
\hline Condiments & 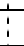 & 2 & 2 & 2 & 2 & 3 & 4 & 5 & 6 & 6 & 3 & 2 & 2 & 39 \\
\hline Honey & 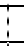 & 3 & 3 & 3 & 3 & 6 & $10^{*}$ & 9 & 9* & 10 & $8 *$ & 5 & 3 & 72 \\
\hline Jams/ Pres. & 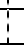 & 2 & 2 & 2 & 5 & 13 & 17 & $20^{*}$ & 21 & 19 & 17 & $11^{*}$ & $8^{*}$ & 137 \\
\hline Salad Dres. & 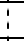 & 0 & 0 & 0 & 1 & 2 & 2 & 2 & 2 & 2 & 2 & 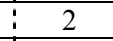 & 0 & 15 \\
\hline Soaps & 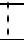 & 3 & 3 & 3 & 5 & 5 & 5 & 5 & 5 & 5 & 5 & 5 & 5 & 54 \\
\hline Wool & & 0 & 0 & 1 & 1 & 1 & 1 & 0 & 0 & 0 & 0 & 0 & 0 & 4 \\
\hline Other: & 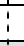 & 3 & 2 & 2 & 3 & 4 & 4 & 5 & 5 & 5 & 6 & 3 & 3 & 45 \\
\hline total & 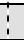 & 16 & 15 & 16 & 29 & 47 & $\begin{array}{l}61 \\
\end{array}$ & : 70 & 72 & : 73 & $: 65$ & 44 & $: 30$ & 535 \\
\hline
\end{tabular}




\section{APPENDIX E:}

Educational Needs as Identified by Farmers' Market Vendors 
- Community Supported Agriculture

- Input and support from government agencies paid to do something!

- Pest control

- More information on insect control such as white flies, and more tips on deer control. This is one of our biggest problems.

- Development of a production working group that could keep us appraised of best varieties of commonly grown crops for our area.

- How to keep other growers (non-vendors) from throwing their excess produce over the hill and instead getting it to the market.

- Grants for more farm development; hydroponics by organics.

- The benefits of buying local produce.

- Time management and planning.

- Making cheese on the farm.

- Better site for market that people (elderly) would walk to; signage

- More knowledge about blight and weed control, insecticides, insects, and where to purchase insecticides

- How to get or find a USDA poultry \& rabbit processing plant in our area

- Educating consumers about local food when in season and regulation to keep out-of-state produce out, with taxes paid to West Virginia.

- Recipes/organic information for customers.

- Pest control, both organic and non-organic.

- I'd like to hear reports about how other local markets fared in '04. I wish we had a hotline where we could describe a specific growing/pest problem and get a solution.

- Soil knowledge. 
- Lots of times there are programs available and we are not aware of which could help the farmer financially. These programs need to be reported to everyone, not just a chosen few in the counties.

- Commercial property.

- To have a trial or demonstration farm to try new practices, new varieties and new ways to produce products from a WV farm.

- Combining market with other attractions.

- Educating customers about local foods; display, signage, and health regulations for processed products.

- Business management.

- Keep all pin-hookers off of farmers' market.

- Possibilities for hemp production and processing.

- Meeting such as held by groups like MOFFA, IFO and PASA, where farmers share ideas.

- Need to know about vouchers in time to plan planting.

- Educate young adults about preparing for canning and freezing and buying in larger amounts to get a better price.

- Information for consumers on why taking the time to purchase local produce is a benefit to them.

- Have definite rules govern the market and not change from week to week.

- Honeybees.

- How to establish markets in new areas.

- The WIC program.

- Newsletter from WVU Extension Office how and what is happening at all West Virginia Markets.

- Sources for reasonably priced packaging and labels. Laws and regulations on labeling. Especially nutritional content. Where to get testings for nutritional values. Examples of what restaurants and groceries expect of producers. 
- Stop the out-of-staters from selling vegetables they buy from the south and selling them at a lower price at the farmers' market.

- Being able to accept WIC \& Senior vouchers for more products (eggs)

- You need to find "market masters" who are fair and impartial to everyone and enforce the rules equally to everyone.

- How to propagate or plant cuttings, especially rhododendrons, smoke trees, etc.

- Labor certainly is a topic, as well as stress. Also no-till organic.

- Weed control, pest \& deer control.

- New \& helpful techniques.

- Market liability insurance, business license requirements.

- Consulting with total market vendors to help them see ways to improve overall market (i.e. higher fees to provide better $\&$ more advertising that benefit entire market).

- Dwarf fruit tree pruning.

- Local support.

- To get articles in new local papers concerning the market, especially the opening.

- How much competition at a market is fair? Should it be free-market, supply \& demand?

- Varieties for diversity at market.

- Information earlier on varieties, not after seeds are ordered. 
APPENDIX F:

Obstacles to Success as Identified by Farmers' Market Vendors 
- We grow organically but are not certified and are retired. Younger households work two jobs and don't cook or can. Not many people buy in bulk. Any people that still can are older.

- People who don't grow their own food/produce, and then bring it to farmers' markets to sell. If you are the one growing it, then sell it. Don't go out and buy it and then resell it.

- Due to my small amount of produce, it does not pay me to raise a garden. I work a full time job and only have a small garden. With the rain we had in 2003 and 2004, I have not made a profit on my small amount of produce, and I have decided not to sell again.

- Age and bad health

- I am only a backyard hobbyist

- Recognition of programs, communities, and the government. All agencies are not aware of what is going on!

- Need to develop younger customer base.

- Government over-regulation

- Market rules are not followed; there is favoritism.

- More than $50 \%$ of our market sales were WIC or Senior FMNP vouchers. We need to convince more people to shop and spend cash. [Instead] they go to the local Wal-Mart!

- Being older and not able to grow as much and having to travel $30+$ miles each way.

- Deer problems: suffered a big loss the last 2 years due to deer. We use electric fences, tall fences, purchased spray controls, etc. Still at a loss on how to save our vegetables, which were untouched by deer before a couple of years ago.

- Also problems with tomatoes due to white flies. Have used many products, but have destroyed our tomatoes and are now starting to eat cukes and zucchini.

- The most common complaint I hear about is the lack of good reliable labor. The only way I could deal with the problem was to set an operation up that I can run by myself. It would be very helpful if there was some temp service we could call and get day laborers when we need them.

- In 2004 Spring frost damages apple crop. Then fire blight really hit the orchard hard, and I had only $25 \%$ of the crop harvestable. Deer completely wiped out bell pepper crop and caused much damage to hot peppers, cukes, tomatoes and beans. Deer damaged my PYO blackberries. Now I have a different shotgun and I expect crops to be better in 2005. 
- Local cooperation from city and county governments is needed to provide good market location and advertising.

- I would like to have another market comparable to the Weirton farmers' market's site and size.

- There was truly a farmers' market in prior to 1997. For some unknown reason to me the WVDA teamed up with business interests in millions of taxpayers' money to create a market called and somebody spent my tree sales were $55 \%$ of the former farmers' market. Sales have decreased every year since. I'm a taxpayer. Strange to me!

- Few vendors; few customers; poor location; and a lack of advertising for senior voucher program. A lack of interest on the part of committees of Aging, both here and in surrounding counties, to make a day trip when the market was planned for them; poor historical image (i.e. "we did that- it didn't work"). Otherwise, things are just hunky-dory!

- Non-farmers selling at market; half of markets total income often is received by nonfarmers (i.e. pin-hookers) or larger non-farmers.

- We need grants or funding to revive old fruit orchard.

- Too much competition.

- Distance I have to travel to the market. We need a building in which to hold our market, and make people more aware of the market.

- The time spent is by choice, but still, need to go home, work up the extra produce and do the chores. So advertising is very important; to do the extra work to prepare for it [market] needs to pay off $(\$)$ somehow.

- __ has lung cancer and is very ill. He will no longer be able to continue gardening.

- The more people we have, the better the market is. It depends on how much sold as to what profit you had. Some days a lot of things didn't sell, so we took them home and used them ourselves.

- Inside politics at some markets are an obstacle.

- We need more cooperation from state Department of Agriculture, who doesn't understand their own rules.

- Confusing, inconsistent, and arbitrary rules concerning handling of eggs and frozen meat products. 
- I participated in the uptown Tailgate Market last summer, and sold a variety of homemade baked goods. The market was extremely under-publicized and as the season wore on, we got fewer and fewer customers. It was supposed to be in conjunction with "Fridays in the Park". However, we were forced to set up in a lot at least 1/4 mile away from there. Most of our business was limited to employees of the surrounding office buildings, not people from the Fridays in the Park. If our market (which was in its first year in 2004) is to experience any growth-or even be worth the vendors' time. In 2005 , it needs more advertisement and location nearer the Fridays in the park.

- Our site is isolated off the road, with the market space down stairs, set back from the street, with very poor signage. Little community outreach. Seniors appear unaware that vouchers are free. No noticeable WIC outreach.

- People hauling out of state produce to our market to sell, which is strictly against our rules and regulations. Cut-throat pricing in order to sell their produce that was hauled in. This is what hurts the true farmer in the area.

- I cannot participate full-time, since pawpaws have their own time schedule. And with a handicapped wife, my time is limited also.

- Imagination.

- Not enough time and energy to get everything done!

- None in the market I which I participate. Monthly leases enable vendors to provide dynamic displays of diverse, quality products... outdoors. With proper security, parking, and customer volume, success is a given. We don't need a Tamarack. Don't need to pay rent for after hours wine and cheese or "how to" shows on Mother's Day. Don't want a flea market either. There are 20 plus outdoor vendors at the Market when it opens this spring. If there were similar markets, we would be there.

- Zoning regulations in Jefferson county (inconsistencies), lack of poultry processing (USDA inspected) access in our area. Inconsistencies of Health Dept. rules and regulations from county to county and state to state. When rules differ in counties within a state it is very hard to determine what you can and can't do. I thought we are supposed to be reading from the same book! (Father/daughter business).

- Educating local consumers, plus some help to work with local stores, maybe chains.

- I fell seriously ill last summer. Usually we make over $\$ 10,000$ in a season, but last year was less than $\$ 500$. I usually devote more time to the crops, but 2004 was very unusual year. I usually have $80 \%$ of the crops listed (on pages $4-5$ ).

- I'm getting older and production is getting more expensive.

- Wal-Mart, which is putting everyone and everything out of business. 
- Very time consuming if you want to do a good job and give consumers high quality products. Plus working off the farm and completing farm chores. But, it is very enjoyable (most of the time).

- I don't perceive any obstacles. I love the people/customers who come to the Wheeling farmers' market. The other vendors are terrific to work with; it's a great atmosphere! We're a small, family owned farm with 30 acres and 2 sons ages 8 and 10. I'm a teacher while my husband works off-farm full-time. Our main motivation for attending the market is to raise tuition for our sons' private education. We're maxed out on time and energy to put into the farm.

- Don't know enough about how to fight all the pests. I think the 'official scale' that vendors are required to have is very prohibitive at these little markets, if they don't have one. If we would have had to pay rent, we could not have done it. There aren't enough market days to 'jive' with the days I have stuff available. I need a truck to haul manure. I need regular education and specific help for pests and diseases. I need the laws about killing deer who eat my garden rescinded. Lack of customers, and a lack of the right produce when people want it is also a problem.

- Crop management, staggered plantings, and harvesting are obstacles.

- Our local market (_ more than one occasion I have been there at 4:30 and found that it had already opened, with the main customers have bought and left. Any others that come in stop at the first 2 or 3 stands (the market masters'), purchase and leave. What are we supposed to do with our produce we have picked and ready to sell? It won't last until Saturday, so we give it away or throw it away. The reason for opening early was that they thought it was going to rain. I would appreciate a solution to this problem through a response from you. I believe the vendor spaces should be rotated weekly, giving each farmer a chance to sell. Thanks.

- The local health department rules and regulations for eggs, which they consider a "potentially hazardous food" They are kept in a refrigerator at the market.

- Too many producers with the same products. Need more vendors with different items.

- Weather.

- I appreciate the growing, packaging, selling and all aspects of the farmers' market. We have become very good friends with the other producers and the consumers. The coupons help those consumers who otherwise would not have the extra money to purchase fresh fruits and vegetables. That is why our county gives out so many coupons; the elderly and young mothers enjoy being able to get fresh fruits and vegetables. Sometimes people from other counties come to our market. They car-pool here to get good fresh foods because their county doesn't have a farmers' market.

- I am not really a farmer. I sell some excess produce at farmers' markets, to one restaurant, and several people. 
- The biggest obstacle I see is that we are losing our customer base. Most people who cook are aging. Over the past, I have seen people's buying habits change. For example, people buying corn used to buy 1-2 dozen, but today they will buy 3-4 ears. Younger people do not cook more than 2-3 meals a week compared to the older generations that cooked every day. Volume sales have been in decline in the past few years. More needs to be done by farmers' markets to draw middle-aged customers with families to buy produce. Also, I feel that the main purposes of farmers' markets are to supply local produce to the local community and to enable the local farmer to get a retail price out of products. Not to have vendors who buy in produce from wherever available the cheapest and call it homegrown. Such as is done at Capitol Market!

- We need more equipment and licensed commercial property to increase production.

- We need a set time (hours) and to not allow people who don't raise it themselves.

- Past 80 years.

- Quite a few buyers are too lazy to cook, and they'd rather have it already cooked. Lowincome families buy very sparingly, if at all.

- In the case of the farmers' market in , too many people are trying to establish rules \& regulations and using large-scale models (i.e. Dupont Circle) as examples. This is not D.C., let the market grow on its own and don't try to make it something it isn't. Too many people are not even involved in production or sale trying to add their two cents. Should possibly look into another location for the market. All in all I am not pleased with the direction of the Morgantown farmers' market. The 2 grad students last year did an excellent job! It is some of the producers and others who are making a mess of it! I would be better off selling along the road!

- Time is a major factor, when working a regular job.

- This market needs more vendors to encourage the local people to purchase. The selection available for sale here is limited. Growers here do not feel that it is worthwhile to grow for the market. Some sell surplus, some simply give away any surplus produce they grow.

- Too many pin-hookers at the market. I go to Ashland, Kentucky market because they try to keep pin-hookers off.

- Do not let in vendors who do not raise what they are selling as this is not fair to those of us who are working hard to raise our own crops.

- Market promotion is a big obstacle- Markets can't just be about products, but also must be about community. The market has to be a gathering point. There is a need for fun such as music or demonstrations or prepared food. 
- Vendors not obeying rules regarding selling purchased produce. Vendors feeling that they must charge a very low price.

- To be successful, a farmers' market must have a set time of operation, rules and regulations that are enforced. A good manager and be a 'growers only' market.

- The one thing that gets me upset about the farmers' market is that a vendor buys a lot of produce out of state and brings it to the market, selling it as home-grown. He is a farmer from out of the county/state. He grows some of his own vegetables but not enough to have the quality and quantity that he's bringing to the market.

- Weather and insects.

- As much as people would like to have fresh produce...convenience still plays a part in purchasing. Farmers' markets generally FORCE people to come on a certain day only for a few hours (sometimes only four). I would think common sense would let you reason you are missing a lot of potential customers. A problem of extending days or hours for the market. Location of markets can be limited in availability because of days or hours. Farmers- will they have enough product or staff? We need more farmers, but profitability is a part of the picture. We are in need of GRANTS for high tunnels, wells for irrigations, deer fence, wind turbines....

- More farmers' market locations would be helpful (Raleigh county?). Farmers' market in needs a 'farmers' market this exit' sign on Exit 100. People traveling look for these signs and they have never had one. the old market used to have.

- We have very little help or guidance from the Extension office. There are no outreach programs concerning information from the Agriculture Department. Our market association has not had a meeting now for 2 years. Our market master makes rules different for each member and conducts the whole activity as though it were a business and he the owner. I believe that there is enough good that comes from these markets to enrich the community and encourage young people to participate at least in the future. I believe that some day the market will be conducted in a correct manner and will then better benefit both the community and vendors.

- We should be able to sell produce or plants at my market in Kentucky, West Virginia or Ohio, not a 30 or 50 mile radius. You should be able to raise $50 \%$ and buy $50 \%$ local produce or plants in the three states.

- Success can be measured in many different ways, so the obstacles could and can and will approach infinite. The lack of understanding about food systems on the part of the consumer, I think, keeps him or her from seeking out local food sources. Also, human love of gluttonous easy living and puzzling self destructive behavior is an obstacle. Helping people truly care about and for themselves seems to be at the center. 
- An obstacle I come into contact with is vendors that take up more space than necessary. Also, another local "farm" market that ships in vegetables and sells them "dirt" cheap.

- Truck farmers or box farmers, buying quantities of produce to dump into the market.

- The main obstacle is old age (retired).

- We need more vendors to sell, I would like to see $4 \mathrm{H}$ projects for farmers' markets. All year selling of lettuce, etc. from growers who have greenhouses, since mesclun is very hot now. We sell bedding plants, super vegetable in 3 states (NC, VA, WV) April 1 through June 1. Priced 50 cents more for a six pack of plants. Flea markets are not farmers' markets.

- Limitations on electric supply.

- Poor leadership by market master. Most people in this area are not acceptable to change. Going to leave this area to get better prices and better customers.

- Our one and only farmers' market is only open on Sunday 10 a.m. to 2 p.m. I must find other ways to sell my products. If it wasn't for roadside stands and selling at a stand at home, it's difficult to stay alive. But on the other hand, I produce enough to last all winter whether it be canned, frozen or dried.

- The market, after 9 years, still has no sign on I-64. [The market is in] a big ugly brick building that blocks the view of drive-by traffic.

- By allowing non-farmers to participate in the WIC/Senior program- they should not be allowed to participate. This causes a hardship on local farmers. Many people truck items from other surrounding states and call it local produce. They price items lower and make it difficult to compete. They are not true farmers.

- Older generations of farmers unwilling to adapt to new rules, marketing techniques and crops.

- Hard work and good vegetables and berries and nuts.

- Vendors who go to produce markets and buy produce to re-sell at farmers' market.

- Having one on one contact with the customers, answering questions about my product honestly and overall being a people person!

- Lots of hard, enjoyable work. Get up early, go to bed early. Grossed \$2,600 in 2004. Most of sales from roadside stand beside my home. $3 / 4$ acre plot. 
- Not being able to accept WIC \& Senior vouchers and not advertising to all age groups. Probably $95 \%$ of the consumers at our market are 65 years old or older. We need more young consumers.

- The biggest problem I see on the horizon is keeping the farmers from squabbling amongst themselves about places to set up, etc.

- Age and health, since I'm retired from public education. But I LOVE doing this. When I cannot do this any more, I surely will sorely miss both the gardening and especially the socializing at the market.

- Some farmers' markets in WV will not allow Non-residents (Ohioans) to sell, which is funny because many vendors who sell in WV purchase their products from elsewhere (i.e. many of the products are grown on the Ohio side of the Ohio river. I would like to see growers sell their own products or a large percentage, instead of resale from some vendors which allow the vegetables to be older and not as fresh.

- We have a wonderful farmers' market on Sundays in , outdoors with 1618 vendors.

- Local health regulations are applied indiscriminately and with confusion even by inspectors themselves. I should be able to give tomato samples to customers w/o fear. Coffee should be allowed for sale in order to foster environment conducive to lingering. Outdoor, permanent structures would likely make us more successful on rainy days \& on very hot days. Customers would still come. Better/more advertising in the earlier part of the season when I still went home with stuff would be helpful. Shifting hours later would make me nicer, having had more sleep, and it would fit better with University town hours. The State Department of Agriculture should be a wealth of resources on all rules relating to farmers' markets. Instead, they are silent and a dearth of info is on their website. They talk about support of family farms, but that's it. Instead they are throwing all support to big industrial agriculture (i.e. poultry industry). This model is an obstacle to my success as a farmer wherever I market my produce. That model takes away my individual freedom to make a living as I see fit because it does not fit into the prevailing corporate formula that is paid to pander to.

- My success is tied directly to the success of the market. There is a need to educate consumers about why buying locally is important.

- I would appreciate a permanent, covered market

- Too many large out of state vendors who bring in products from the eastern shore of Maryland, flooding the markets and putting the local farmers out of business. These farmers; markets were designed for local growers, not out of state vendors who grow nothing. 
- Illegal price setting and price fixing by full-time commercial farmers as they don't want competition. Sherman Act: www.electran.org/laws.asp

- The main obstacle for success as a farmers' market vendor is obtaining liability insurance.

- The large number of pin-hookers who sell at the Market, pretending like they're farmers. It's a joke. These people are also taking vouchers, which is against the law. You should do a sting operation and bust all of those liars and cheats. I'm ashamed to say, but most are from Ohio. Not all, but most. Also, we need a larger customer base.

- Out of state vegetables and fruits being sold in West Virginia. Store owners buying wholesale and selling at farmers' markets. in is a very good market manager

- The narrow minded attitude of some other vendors who fail to see benefits of advertising, marketing, good signage, etc.

- Too many vendors buy their produce from shippers and sell it as 'home grown'. You do not have peaches in early June, or Apples either. This needs to be policed more closely.

- I can't think of anything. The only thing that has hurt us is the wet weather. We had to buy potatoes at the store this year, the first time in years. We had a lot of seeds rot in the ground. We have really lost on our garden in the last few years.

- Small acreage.

- Our market has no organization, no one in charge. Our local town doesn't seem to want to support us (group of vendors selling agricultural products).

- I have a health problem which I hope to overcome.

- Fear of competition.

- The location of the market, poor distribution of peak crop production of various crops such as tomatoes.

- 1) Higher cost of production (seed, fertilizer, machinery, fuel, etc.)

2) Labor-- too many people on welfare who won't work.

3) Public uneducated about production costs

4) Out of state vendors buying products to sell (over $85-90 \%$ of what they're selling)

5) Vouchers limited to vegetables, when they should include meats and eggs, for those meats which are state and federally inspected and refrigerated.

6) Lack of electric and restrooms 
VITA

\section{Stacy M. Miller}

May 2005

May 2004-May 2005

April 2003- November 2003

November 2001 - November 2002

May 2001

January 2001 - November 2001

May 2000-November 2001
Master of Science in Agricultural \& Environmental Education

West Virginia University Morgantown, WV

Graduate Research Assistant West Virginia University Extension Service Supervisor: Thomas McConnell, Farm Management Specialist

Morgantown, West Virginia

Cut Flower Manager

Blue Ridge Center for Environmental

Stewardship

Supervisor: Christine Qualls

Purcellville, Virginia

Program Coordinator

Service \& Social Change Program

AmeriCorps*VISTA

Supervisor: Dr. Nancy Danganan

St. Mary's College of Maryland

St. Mary's City, Maryland

Bachelor of the Arts in English

Major: English

Minor: Environmental Studies

St. Mary's College of Maryland

St. Mary's City, Maryland

Program Assistant

Tobacco Transition Program

Supervisor: Dr. Christine Bergmark

Tri-County Council for Southern Maryland Hughesville, Maryland

Forewoman

Even' Star Organic Farm

Supervisor: Brett Grohsgal

Lexington Park, Maryland 